National Uranium Resource Evaluation

\title{
VOLUME 3 \\ URANIUM ASSESSMENT FOR THE \\ PRECAMBRIAN PEBBLE CONGLOMERATES \\ IN SOUTHEASTERN WYOMING
}

\author{
By: Leon E. Borgman \\ Cassandra K. Sever \\ William F. Quimby \\ Michael E. Andrew \\ Robert S. Houston \\ Karl E. Karlstrom
}
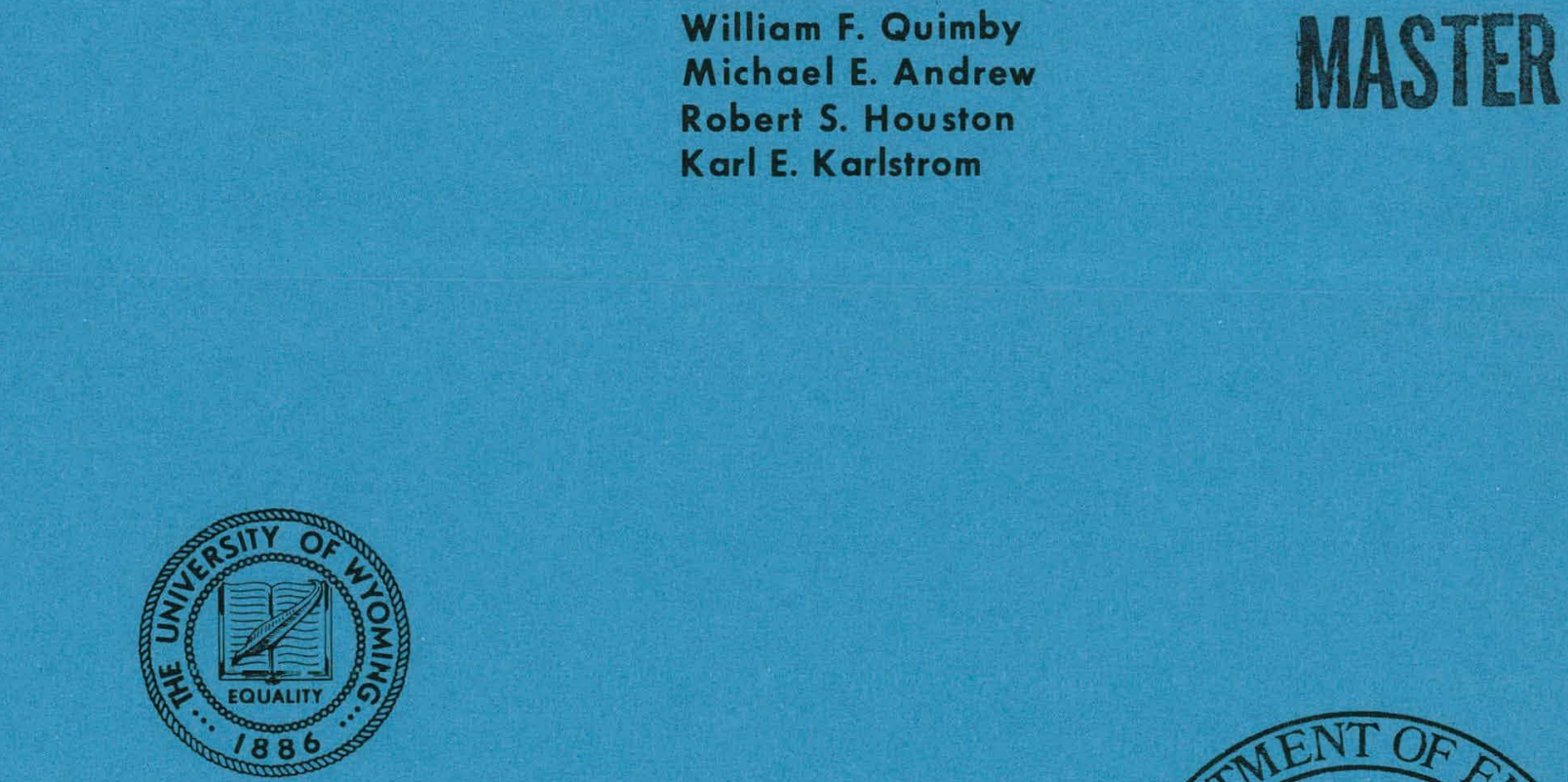

UNIVERSITY OF WYOMING

Laramie, Wyoming

February, 1981

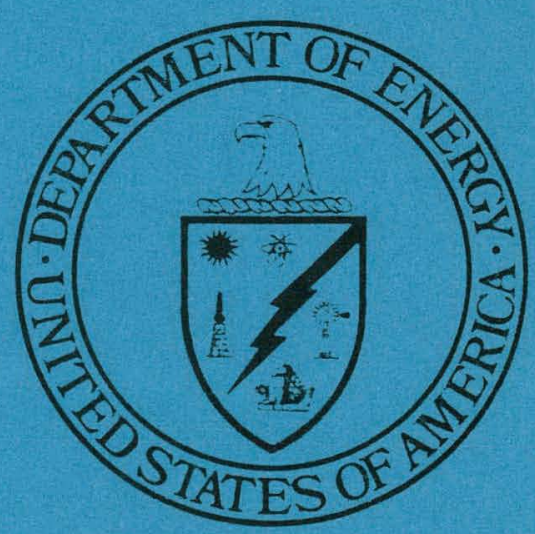

PREPARED FOR U.S. DEPARTMENT OF ENERGY

GRAND JUNCTION OFFICE, COLORADO 


\section{DISCLAIMER}

This report was prepared as an account of work sponsored by an agency of the United States Government. Neither the United States Government nor any agency Thereof, nor any of their employees, makes any warranty, express or implied, or assumes any legal liability or responsibility for the accuracy, completeness, or usefulness of any information, apparatus, product, or process disclosed, or represents that its use would not infringe privately owned rights. Reference herein to any specific commercial product, process, or service by trade name, trademark, manufacturer, or otherwise does not necessarily constitute or imply its endorsement, recommendation, or favoring by the United States Government or any agency thereof. The views and opinions of authors expressed herein do not necessarily state or reflect those of the United States Government or any agency thereof. 


\section{DISCLAIMER}

Portions of this document may be illegible in electronic image products. Images are produced from the best available original document. 
This report is a result of work performed by the University of Wyoming through a Bendix Field Engineering Corporation Subcontract, as part of the National Uranium Resource Evaluation. NURE is a program of the U.S. Department of Energy's Grand Junction, Colorado, Office to acquire and compile geologic and other information with which to assess the magnitude and distribution of uranium resources and to determine areas favorable for the occurrence of uranium in the United States.

This report was prepared as an account of work sponsored by an agency of the United States Government. Neither the United States Government nor any agency thereof, nor any of their employees, makes any warranty, express or implied, or assumes any legal liability or responsibility for the accuracy, completeness, or usefulness of any information, apparatus, product, or process disclosed, or represents that its use would not infringe privately owned rights. Reference herein to any specific commercial product, process, or service by trade name, trademark, manufacturer, or otherwise, does not necessarily constitute or imply its endorsement, recommendation, or favoring by the United States Government or any agency thereof. The views and opinions of authors expressed herein do not necessarily state or reflect those of the United States Government or any agency thereof.

ititin? 
VOLUME 3

\title{
URANIUM ASSESSMENT FOR THE PRECAMBRIAII PEBBLE CONGLOMERATES IN SOUTHEASTERN WYOMING
}

\author{
By: Leon E. Borgman \\ Cassandra Sever \\ William F. Quimby \\ Michael E. Andrew \\ Karl E. Karlstrom \\ Robert S. Houston
}

UNIVERSITY OF WYOMING MARCH, 1981

\author{
PREPARED FOR THE U.S. DEPARTMENT OF ENERGY \\ GRAND JUNCTION OFFICE, COLORADO \\ UNDER CONTRACT NO. DE-AC 13-76GJ01664 \\ AND BENDIX FIELD ENGINEERING CORPORATION \\ SUBCONTRACT 79-345-E \\ WORK DONE IN COOPERATION WITH IHE UNITEU STATES \\ GEOLOGICAL SURVEY AND THE GEOLOGICAL SURVEY OF WYOMING
}

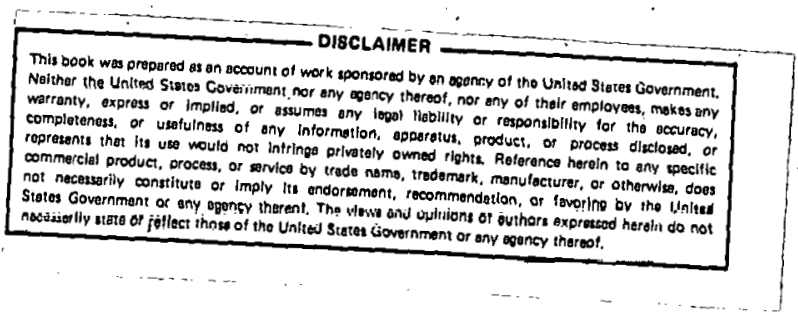


THIS PAGE

\section{WAS INTENTIONALLY LEFT BLANK}




\section{CONTENTS}

Page

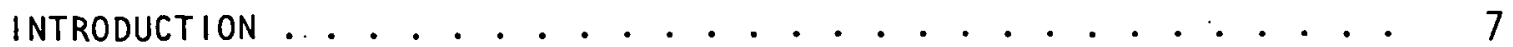

SUMMARY OF THE GEOLOGICAL DESCRIPTION OF THE DEPOSITS. . . . . . . 12

Geology of the Sierra Madre Deposits. . . . . . . . . . . 12

Geology of the Medicine Bow Deposits. . . . . . . . . . . 16

OUTCROP AND DRILL CORE SAMPLING PROCEDURES . . . . . . . . . . . . 21

Outcrop Sampling Plan... . . . . . . . . . . . . . . 22

Drill Core Sampling Plan................ 26

OUTLINE OF GEOSTATISTICAL METHODOLOGY AND THE STATISTICAL

PARAMETERS OF THE DEPOSIT. . . . . . . . . . . . . . 31

The Variogram . . . . . . . . . . . . ... . 31

Kriqed Estimates. . . . . . . . . . .. . . . . 35

The Sampling Relation in Figure 5... . . . . . . . . 37

Lognormal ity of $\mathrm{U}_{3} \mathrm{O}_{8}$ and $\mathrm{ThO}_{2}$. . . . . . . . . . . . . . . . 39

The Variogram Parameters. . . . . . . . . . . . . . . . 43

PREDICTION EQUATIONS FOR LEACHING. . . . . . . . . . . . . 49

THE RESOURCE DETERMINATION ................... . . 59

The Basic Kriging Relation. . . . . . . . . . . . . 59

Computation of Probable Error . . . . . . . . . . . . . 62

The Resource Computations . . . . . . . . . . . . . . . 65

Judgements Concerning Geological Uncertainty. . . . . . . . 72

SUMMARY AND CONCLUSIONS. . . . . . . . . . . . . . . . . 91

REFERENCES CITED . . . . . . . . . . . . . . . . . . . 95

APPENDICES . . . . . . . . . . . . . . . . . . . . . . . . 97

Appendix A - Mathematical Derivations . . . . . . . . . . . 97

Appendix B - Detailed Tabulations of Deposit Geometry . . . 107

Appendix C - Graphical Presentation of Placement and True Thickness of Ore Beds in the Outcrop Transects and the Drill Holes. ............. . 127

Appendlx D - Average Grade and Total Bed Thickness for Outcrop Transects and Drill Holes. . . . . 153 


\section{ILLUSTRATIONS}

Figure

Page

1. Map of southeastern Wyoming with Precambrian Geology. . 8

2. Location Map of Northwestern Sierra Madre. . . . . . . 15

3. Geologic Map of Onemile Creek Area, Medicine Bows. . . . 18

4. Geologic Map of Threemi le Creek Area, Medicine Bows. . . . 20

5. Probable Error Chart . . . . . . . . . . . . . . 25

6. Typical lsullupic Valiogram . . . . . . . . . . . . . 33

7. Variogram with variance. Zone of Influence, and Nugget. Effect................... . . 33

8. Theoretical Variograms ............. 34

9. Lognormal Probability Plots. . . . . . . . . . . . . . 42

10. Variogran, Conglomerate h; Sierra Madre. . . . . . . . 44

11. Variogram, Conglomerate k, Sierra Madre. . . . . . . . 45

12. Variogram, Onemi le Creek Conglomerate. . . . . . . . . . 46

13. Probability Distribution for Tonnage Correction. . . . . 57

14. Possible Styles of Folding, Onemile Creek Area . . . . . 83

15. Fold Geometries with Mafic Sills, Onemi le Creek Area . . 84

16. Fold Geometries with Mafic Dikes, Onemile Creek Area . . 85

17. Interpretations of Subsurface in Sierra Madre . . . . . . 89

Table

1. Variogram Parameters for Radioactivity, Sierra Madre . . 47

2. Variogram Parameter Values, Sierra Madre and Medicine

Bow Mountains. . . . . . . . . . . . . . 48

3. Modified Average Log Increments for Leaching . . . . . . 55

4. Summary of Urani um Resource Calculations, Sierra Madre . . 67

5. Summary of Uranium Resource Calculations, Medicine Bow Unit l. . . . . . . . . ....... . 68 68

6. Summary of Uranium Resource Calculations, Medicine Bow Unit 5a. . . . . . . . . . . . . . . . 63

7. Summary of Uranium Resource Calculations, Medicine Bow Unit 5b. . . . . . . . . . . . . . . 70

8. Summary of Uranium Resource Caleulations, Threemile Creek Area, Medicine Bow . . . . . . . . . . . . . 71

9. Summary of Thorium Resource Calculations, Sierra Madre . 73

10. Summary of Thorium Resnurce Calculations, Medicine Bow Unit 1...................... 74

11. Summary of Thorium Resource Calculations, Medicine Bow Unit 5a...................... . . 75

12. Summary of Thorium Resource Calculations, Medicne Bow Unit 5b. . . . . . . . . . . . . . . . 76

13. Summary of Thorium Resource Calculations, Threemile Creek Area, Medicine Bow . . . . . . . . . . . . 77

14. Highest Uranium and Thorium Values from Sierra Madre Units 1, 2, and 4.................. 78

15. Maximum $\mathrm{U}_{3} \mathrm{O}_{8}<100$ ppm encountered in Medicine Bow Units. 79

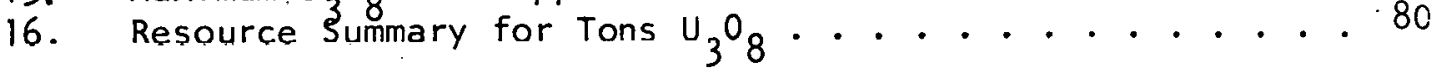


Table Page

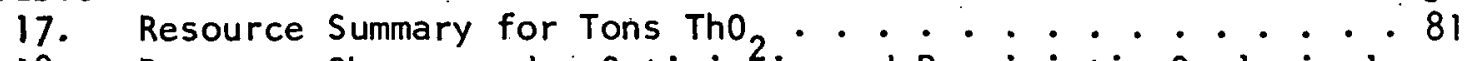

18. Resource Change under Optimistic and Pessimistic Geological Interpretations, Onemi le Creek Area . . . . . . . . . 87

19. Resource Change with Optimistic and Pessimistic

Interpretations, Sierra Madre . . . . . . . . . . . 88

20. Estimated (Subjective) Probabilities of Correctness of

Resource Analysis.............. 88 


\section{THIS PAGE \\ WAS INTENTIONALLY \\ LEFT BLANK}




\section{INTRODUCTION}

Uranium and thorium occur in Precambrian pebble conglomerate metasediments in the Sierra Madre and Medicine Bow Mountains of southeastern Wyoming as shown on Figure 1. The Geology Department of the University of Wyoming was asked to make a geostatistical assessment of the uranium endowment of these deposits as a part of the World Class core drilling operations of the Bendix Field Engineering Corporation. This study was to include (a) the development of optimum geostatistical methodology for assessing uranium endowment in areas of close drill control (1 mile or less centers) as well as in areas of distant drill control (5 mile centers or more), (b) the implementation of this methodology in assessing the uranium resources of the pëbble conglomerates in southeastern Wyoming, and (c) the determination of the overall geostatistical uncertainty of the resource estimates. In addition, methods were to be studied for projecting the assessments into new areas, including prediction of estimate uncertainty.

The resource assessment consisted of four phases of activity. These were (a) a detailed geological study of the configuration, genesis, and structure of the deposits, (b) the statistical design of a sampling plan and the collection of rock samples from drill core and outcrops, (c) the geostatistical analysis of the assays of these samples, and (d). the integrated geological and statistical interpretation of these results to produce resource estimates and error predictions. 


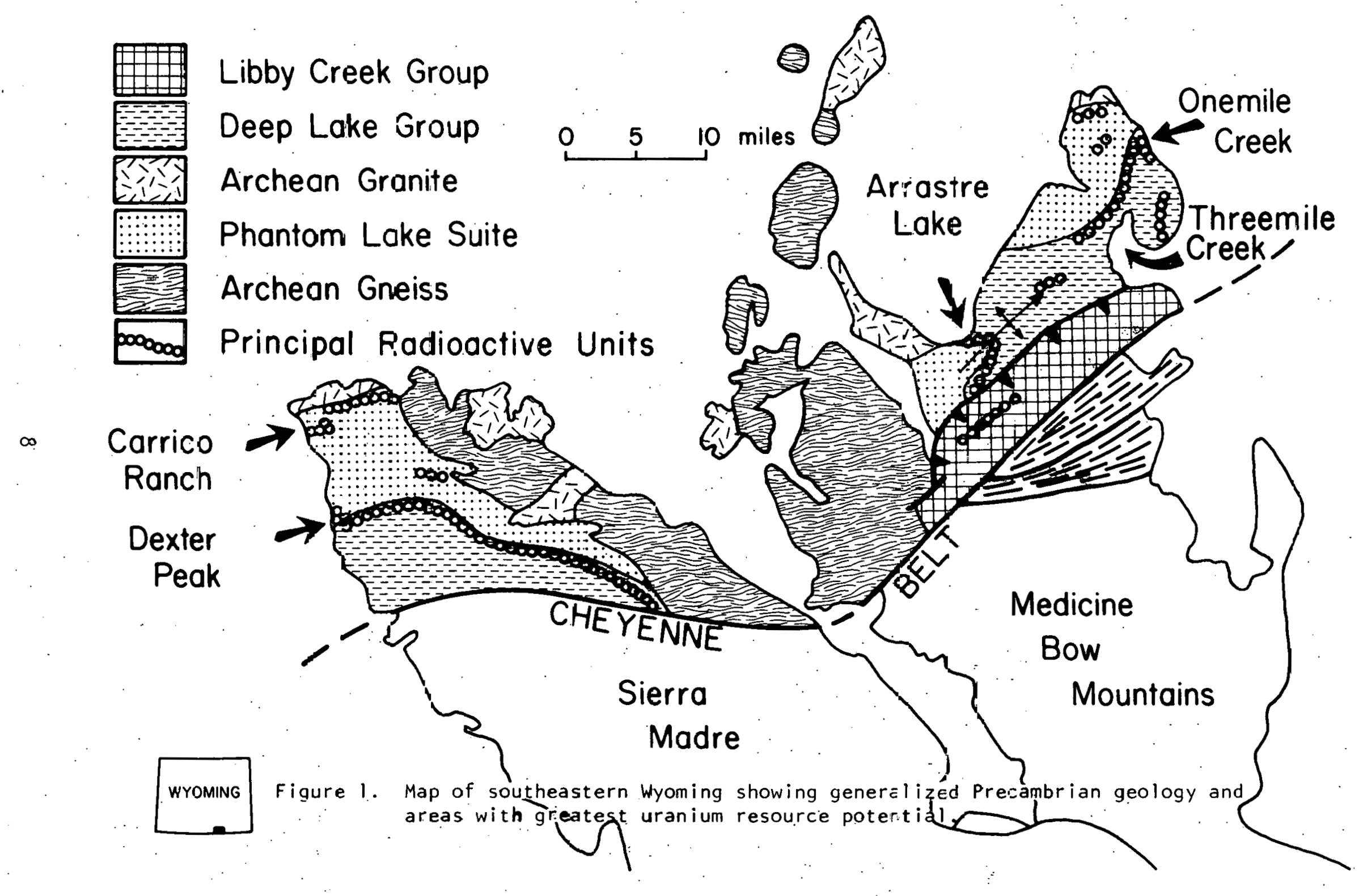


Geostatistical sampling and analysis is somewhat different depending on whether the mineral resource is in the reconnaissance, exploration, development, or production phase of operations. Closely spaced drilling and sampling is characteristic of development and production operations. The sampling can be strongly controlled by statistical considerations with geological interpretations having reduced importance. In reconnaissance and early exploration effort, the geological interpretation is all important and statistics plays a supporting role. Actual data measurements may be quite sparse over large areas and, in the extreme situation of very sparse data, methods based on subjective probability and geological judgment may be the only available procedures.

In the assessment of the uranium endowment in southeastern Wyoming, enough data has been accumulated to form the basis. for estimation with a modified version of optimal averaging called "kriging." This method takes into account spatial persistence of enrichment within the deposit and provides systematic procedures for predicting the errors in the resource estimates: In general, the kriging method assumes statistical stationarity over the zone for which the estimates are being prepared. In practical applications where trends are present, the analysis proceeds in three steps. These are (a) trend removal and various transformations to produce an approximate stationarity, at least, over sub-portions of the ore deposit, (b) the production of kriged estimates for the transformed endowment, and (c) the reverse transformation to estimate the resource in terms of the actual "in-place" endowment. Because the data available from outcrop and drill core is relatively sparse, modifications of the geostatistical procedures are required to remove trends and other 
types of spatial changes in statistical behavior so that data from one area of the deposit can be used to make predictions for other portions of the deposit.

In the southeastern Wyoming study, the principal trend present was that associated with near-surface leaching of uranium by ground water. This varies with depth and possibly; with other mineralogical and physical properties of the host rock; hence, the adjusted values allow the use of surface and near-surface samples to estimate uranlum endowment at depths below leaching horizons. The deposit was divided into smali enough subzones so that horizontal spatial trends did not appear important. Thus, the analysis procedure consisted of an adjustment for leaching, the computation of kriged estimates, and the reverse transformation to predict the actual leached tonnages present in each depth interval.

If a large amount of data had been available from each depth interval (such as would be obtained from closely spaced production drilling on a tight grid), the entire leaching correction and reverse transformation process would be unnecessary. The unadjusted data from each depth interval would be used to predict the tonnage within that interval. In the present situation, the data consists of assays from a large number of outcrop transects perpendicular to formation strike, plus assays from as many drill holes as time and budget would permit. The drill hole data makes a significant and essential contribution to the assessment, particularly in evaluating leaching and geological continuity with depth, but the down-hole encounters of the enriched beds are much too widely spaced both in vertical and horizontal position to allow a simple average of data over each depth interval. Consequently, the three-step procedure of leaching adjustment, kriging, and reverse transformation appears to provide the most efficient use of the data in the resource assessment. 
The uranium enrichment occurs in pebble conglomerate lenses (probably deposited as alluvial fans) scattered through a roughly tabular zone which crops out with an essentially linear strike and which dips fairly steeply (40 to 60 degrees). A convenient geometric model for such tabular deposits is that of a "mineable surface". That is, the thickness of the bed is temporarily ignored and attention is focused on a single bedding plane (i.e. mineable surface) of the formation.

This whole procedure of reducing the three-dimensional ore deposit to a two-dimensional mineable surface is sometimes called the "method of accumulation". It was originally developed for gold deposits in South Africa. It substantially simplifies the geostatistical computations without the loss of essential information.

The areas of the mineable surface within each depth interval provide basic input for the tonnage calculations for that depth interval. All data are projected onto the mineable surface. The total thickness of the beds with $\mathrm{U}_{3} \mathrm{O}_{8}$ exceeding $100 \mathrm{ppm}$ along a given drill hole or surface transect is assigned to the point on the mineable surface where the drill hole or transect encounters the surface. The thickness must, of course, be córrected to true thlckness as measured alung a perpendiculd lo the mineable surface at that location.

The average ore grade is similarly projected along a perpendicular to the mineable surface, using bed thickness as weights.

$$
\text { Average grade }=\frac{\left.\sum \text { (bed thickness } \times \mathrm{ppm} \mathrm{U}_{3} \mathrm{O}_{8}\right)}{\sum \text { bed thickness }} .
$$

The sum is restricted to those beds exceeding a $U_{3} \mathrm{O}_{8}$ grade of $100 \mathrm{ppm}$.

Hence, relative to the mineable surface, the basic data can be reduced to an average thickness and an average grade at each piercement 
of the mineable surface by drill hole or surface outcrop transect. In addition, the areas of. the mineable surface are calculated for each depth interval for which resource estimates are required. The basic relation for resource tonnage is, then, of the general form:

$$
\begin{aligned}
\text { resource }= & \text { mineable surface area } \times \text { average thickness } \times \\
& \text { average grade. }
\end{aligned}
$$

The actual implementation of this relation is quite a bit more complicated, but the basic concept remains correct.

In order for the concept to remain valid, the sampling must be controlled so that the assays along a given transect or drill hole can be regarded as representing a channel sample through the tabular ore zone along a perpendicular to the mineable surface. In the case of uranium and other radioactive elements, the measured radioactivity provides a convenient method to guarantee that all zones with $\mathrm{U}_{3} \mathrm{O}_{8}$ exceeding 100 ppm have been completely sampled. 


\section{SUMMARY OF THE GEOLOGICAL DESCRIPTION OF THE DEPOSITS}

The uranium-bearing quartz pebble conglomerate in southeastern Wyoming occur in two separate areas. One area lies on the Carrico Ranch in the northwestern Sierra Madre, while the other is in the northeastern Medicine Bow Mountains at the Onemi le Creek and Threemile Creek localities. The two areas and some regional details are shown in Figure 1. The geology for each wlll be sumimarized separatcly.

\section{Geology of the Sierra Madre Deposits}

The Sierra Madre region of the Late Archean (greater than $2600 \mathrm{~m} . \mathrm{y}_{.}$) and Early Proterozoic (2500-2000 m.y.) metasediments was evaluated for syngenetic fossil placer uranium deposits. The metasediments in the area fall into two major groups: (1) the Phantom Lake Metamorphic Suite, and (2) the Deep Lake Group (Graff, 1979; Houston and Karlstrom, 1980). These metasediments were deposited in epicontinental and miogeoclinal environments, near the snuthern margin of the Wyoming Archean Province.

Radioactive rocks have been identified near the base of each metasediment group. The Deep Gulch Formation is believed to be near the base of the Phantom Lake Suite and the Magnolia Formation is the base of the Deep Lake Group. The Magnolia Formation was found to be low-grade (less than 10-20 ppm U) over most of the Sierra Madre, so resource evaluation concentrated on the Deep Gulch Formation.

The Deep Gulch Formation is composed of four distinct lithologic units as follows: 


$$
\begin{aligned}
& \text { (lowest) Unit } 1 \text { - Arkosic conglomerate - slightly radioactive } \\
& \text { Unit } 2 \text { - Trough cross-bedded, subarkosic quartzite - } \\
& \text { slightly radioactive } \\
& \text { Unit } 3 \text { - Interbedded radioactive, pyritic, quartz-pebble } \\
& \text { Unit } 4 \text { - Planar cross-bedded, subarkosic quartzites - }
\end{aligned}
$$

Unit 3 is the major target for urarium resource evaluations in the Sierra Madre region. Unit 3 crops out in the northwestern Sierra Madre (see Figure 2) and the area of the unit (see Appendix B) was used as a basis for the calculation of uranium resources in the Sierra Madre.

Unit 3 varies in thickness, but in general, it averages 60-70 feet thick in the western area and gradually thickens to 100-110 feet in the eastern exposures.

It consists of 5-15 conglomerate "reefs" (coalesced conglomerate lenses forming mappable stratigraphic beds) which vary in thickness from 2 inches to 3 feet and in length from 50 feet to over a mile. The thickest "reef" may be continuous for up to four miles.

Radioactive units of the Deep Gulch Formation in the northwest Sierra Madre strike northeast, dip northwest and are overturned. The beds are part of the overturned limb of a large reclined isoclinal fold system plunging west. This structure is further complicated by intralimb reverse faults of unknown displacement.

Because of the complex structure, the subsurface extent of the Deep Gulch Formation is conjectural. For the present resource evaluation 


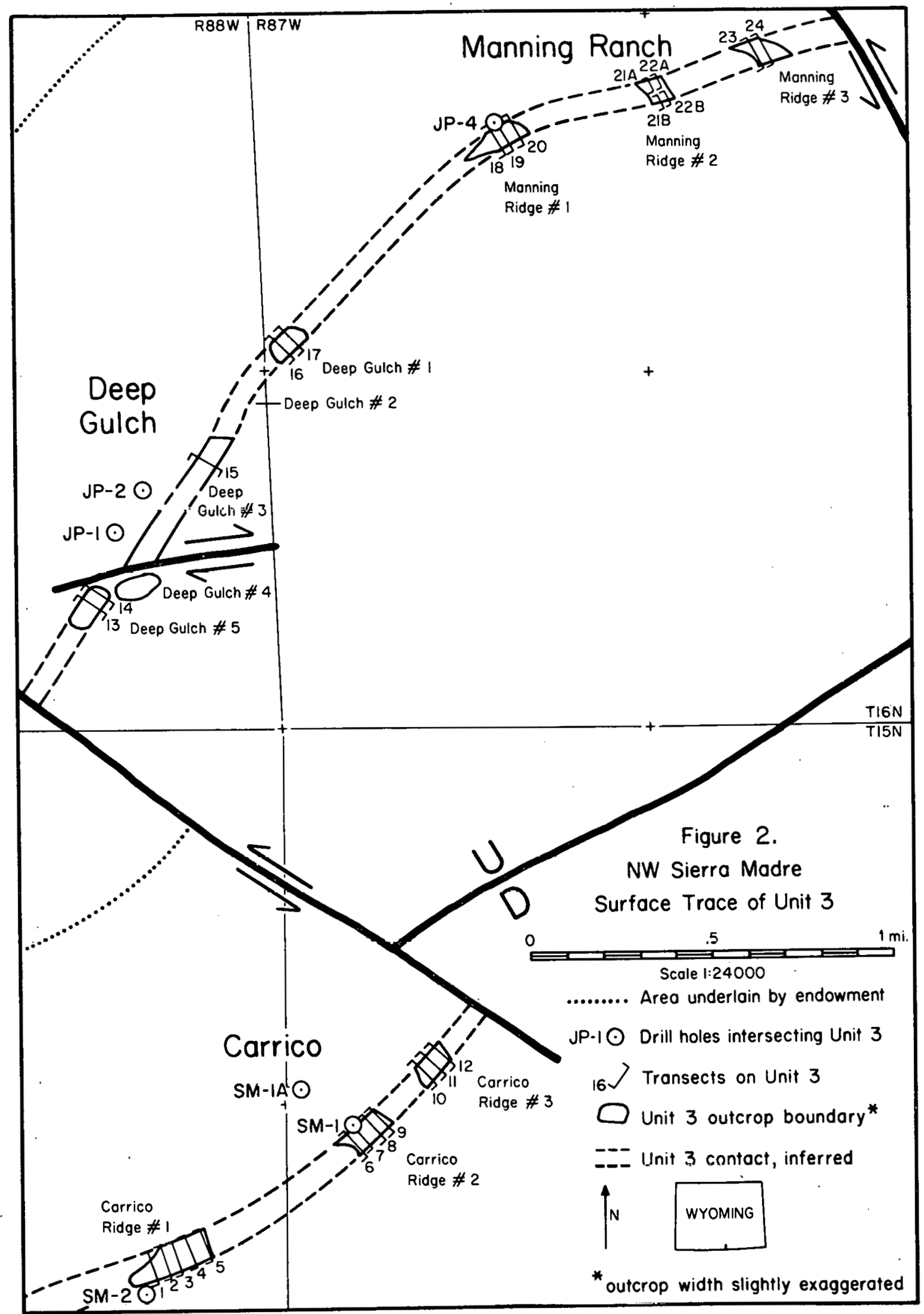


the beds were projected to the depth of 5000 feet for the following reasons.

1. Long outcrop trace suggests significant lateral continuity in a down-dip direction.

2. Drill holes indicate uniform dips to depths of at least 500-1000 feet.

3. Information on the depth to the hinge of the syncline is not available and the uniform projection down dip is the most simple interpretation and perhaps the most reasonable guese, given the exlșilng data.

Geology of the Medicine Bow Deposits

Although the depositional and structural history of the middle Precambrian metasedimentary sequences in the Sierra Madre and Medicine Bow Mountains are very similar, there are minor but important differences between the two areas.

In the Medicine Bows, the Phantom Lake Suite is metavolcanic in the lower part, with more typical quartzite and arkosic conglomerates occurring in the upper part of the suite. Reconnaissance and subsequent work (Karlstrom and Houston, 1979) indicates that although some weakly radioactive zones occur, quartz-pebble conglomerates are absent in the Phantom Lake Suite of the Medicine Bow Mountains. The Magnolia Formation of the Deep Lake Group, however, contains numerous quartzpebble conglomerates, and those in the Onemile Creek and the Threemile Creek areas exhibit substantial radioactivity.

The Magnolia Formation is about $500 \mathrm{~m}$ (1600 feet) thick in the Onemile Creek area and consists mainly of radioactive, muscovitic, granular quartzite and pyritic conglomerates, having much the same character 
as those in the Sierra Madre, i.e. individual lenses which coalesce into a body of mappable proportions. Individual outcrops of these units are variable in thickness and radioactivity, but may be mapped as essentially continuous beds. Three of these units are significantly more radioactive than the others and were the targets for uranium resource evaluation. The extent of these units, designated as unit 1. (which is near the base of the Magnolia Formation) and units $5 a$ and $5 b$ (which are in the upper portion of the formation) is shown on Figure 3 .

The major structure in the Onemile Creek area is a faulted and intruded overturned syncline in the Magnolia Formation. This syncline is documented by top and bottom criteria in the Magnolia quartzites (personal communication, Karlstrom, 1980). Uncertainties still exist in this interpretation. The plunge of the syncline is poorly known and evidence can support either an inclined or a reclined structure. These problems bear on the resource evaluation because a geometry based on the reclined synclinal model will have more extensive conglomerage units than one based on the inclined model. The geometries shown in Appendix $B$, have been based on a simple isoclinal, inclined fold system and the areas calculated are therefore conservative estimates of the area of radioactive zones in the Onemile Creek area.

The Threemile Creek area shown in Figure 4 is located about $11 / 2$ miles south of the Onemile Creek area. Paraconglomerates rather than quartz-pebble conglomerates comprise most of the radioactive units in this area, and correlation with metasedimentary units to the north is difficult because of the less conglomeratic nature of the lithologies and because of the complex structure which separates the two areas. Additionally, 


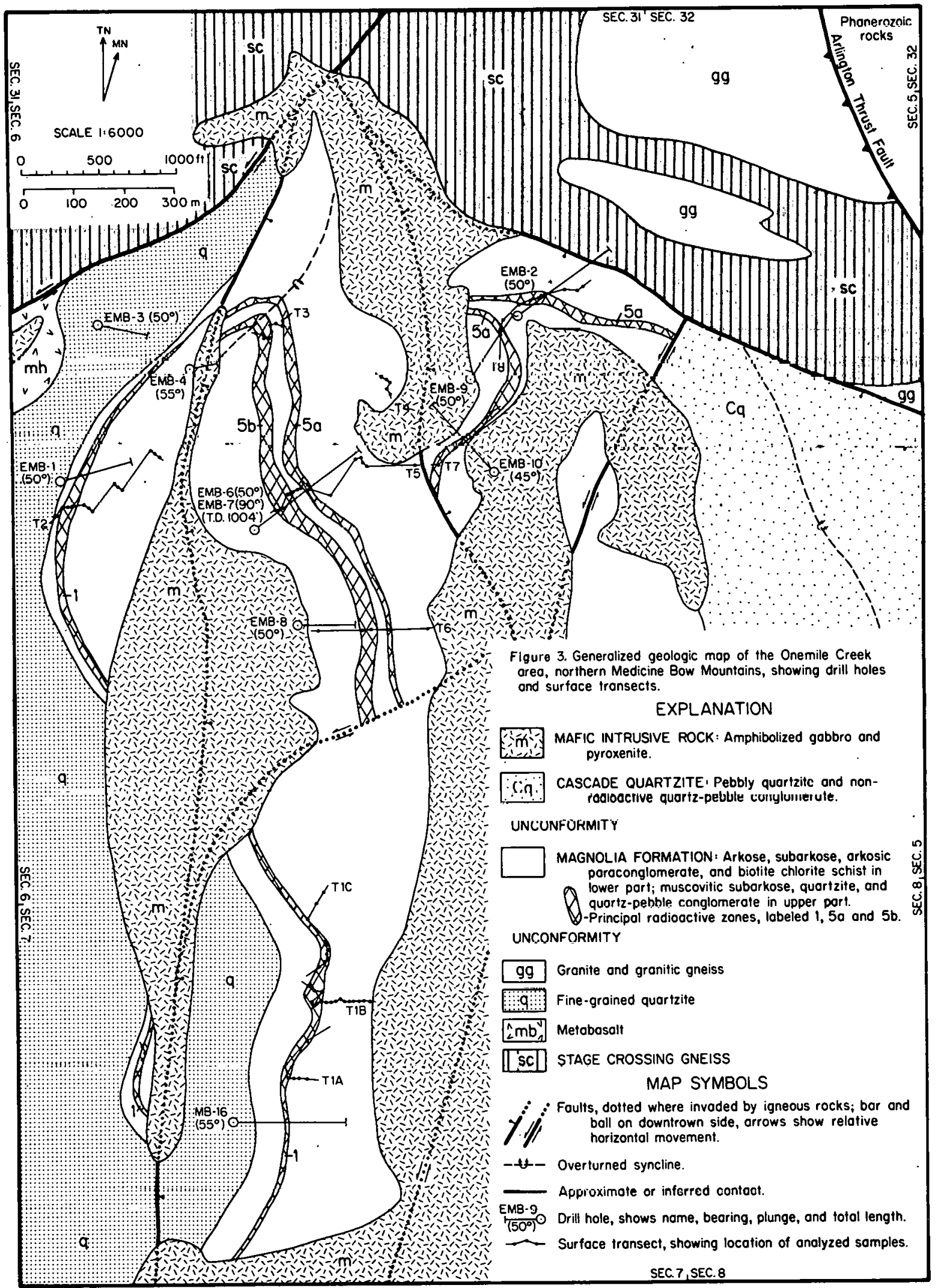


the contacts in the Threemile area are gradational. Karlstrom, Houston and others (Vol. I, this report) conclude that the radioactive units here are basal Magnolia units rather than a facies of the typically paraconglomeratic Phantom Lake Suite but do not extend Onemile Creek stratigraphy into the : Threemile Creek area.

Surface mapping and information from a single drillhole indicate that the principal radioactive zone occurs in beds which form the overturned limb of the Sand Lake Syncline. The geometry used as a basis for the resource estimation is similar to the overturned structures in the Onemile r.repk area. (See Karlstrom, Houston and others, 1981, Vol. 1, this report for detailed discussion of geology). 







\section{OUTCROP AND DRILL CORE. SAMPLING PROCEDURES}

Since the sampling procedures had to be designed early in the project when very little data was available, several weeks of intensive field measurement and mapping of surface radioactivity was initiated to provide a data base adequate to plan further sampling. The geostatistical characteristics needed were the variance, $\sigma^{2}$, of the uranium endowment, the zone of influence, $h_{0}$, (defined as the distance of separation along the strike in a radioactive bed at which two uranium assays become uncorrelated), and the nugget effect, $a^{2}$, (defined as the expectedsquare-difference between uranium assays taken from spatial locations near each other). The variance measures the dispersion of the uranium values, $h_{0}$ characterizes spatial persistence, and $a^{2}$ indicates the amount of local discontinuities present; more detailed definitions and discussion of their importance in the technique of geostatistical kriging will be given in the next section. These three parameters, together with sample size, control the estimation error and are, theretore, needed in planning the number and placement of the samples to be collected.

Spectrometer readings with various separations in distance along radioactive conglomerate layers were used to make preliminary judgments concerning geostatistical characteristics of the radioactive beds. The sequences of readings were taken at 6-inch, 1-foot, and 6-foot spacings along a number of conglomerate layers. The measurement site was on 
ridge 1 and 2 in the Sierra Madre on the Carrico Ranch. The spectrometers were calibrated at the Bendix offices in Grand Junction, Colorado.

The median zone of influence, $h_{0}$, was found to be 10 feet. The nugget-effect-to-variance quotient, $a^{2} / \sigma^{2}$, had a median of 0.62 .

Finally, the average of the standard deviation-to-mean value quotient, $\sigma / \mathbb{V}$ was 0.9. All these characteristics were determined for the uranium acrumulation defined as

$U$ accumulation $=$ (estimates $\mathrm{ppm} U$ ) $\times$ (bed thickness in inches).

\section{Outcrop Sampling Plan}

These geostatistical characteristics provided a basis for the design of an outcrop sampling plan. A variety of possible sampling plans were studied. The method which appeared most appropriate consisted of the collection of samples for assay along transects perpendicular to the strike of the conglomerate beds, supplemented with certain radiometric readings to monitor the geostatistical character of the beds from area to area. The transect procedure for various spacings between lines of samples was studied by two methods. One micthod was by direct analysis via geostatistical formulas. The other method utilized digital simulation on the SIGMA 7 as based on a statistical model incorporating many of the gcological characteristics of the formatinns. The twn methods produced similar results.

The target in a resource evaluation is to produce estimates of the ore reserve with controlled accuracy. One measure of this accuracy is the probable error (PE). The probable error is defined as the median of the absolute value of the error. Fifty percent of the time the error 
magnitude will be less than PE and fifty percent of the time it will be larger. Thus, the probable error is a measure of what the error actually is.

In practice, it is more convenient to work with the relative probable error (PE\%) as compared to the mean value of the deposit. If $\bar{V}$ is the average grade of deposit and PE is the probable error of the estimate of grade, then

$$
P E \%=\frac{P E}{\bar{V}} \times 100 .
$$

The PE\% value is related to $h_{0}, a^{2} / \sigma^{2}$, and $\sigma / V$ the geostatistical characteristics listed in the introduction. The following assumptions are made in the development of the formula.

1. A linear deposit of length $L$ requires a reserve estimate with relative probable error $\mathrm{PE} \%$.

2. The transect values are separated by more than a zone of influence $h_{0}$, from one another. They need not be exactly equally spaced but should be roughly equidistant.

3. The transect locations are not selected so as to "high-grade" the deposit.

4. There is geological continuity between transects in a statistical sense.

5. The average of the variograms along a transect remains about the same along the deposit.

6. The ore block averages being estimated are approximately normally distributed. Generally this will be true by a central limit theorem if the blocks are large, even if the local ore values have some other probability law (e.g., lognormal). 
The formula then is, (with $n=$ number of transects along $L$ )

$$
P E \%=67.45(\sigma / \bar{V}) \sqrt{\frac{1}{n}-\left(1-\frac{a^{2}}{\sigma^{2}}\right)\left[\frac{h_{0}}{L}+\frac{1}{3}\left(\frac{h_{0}}{L}\right)^{2}\right]} .
$$

When $h_{0}=10$ feet, $\sigma / V=0.9$, and $a^{2} / \sigma^{2}=0.62$ are substituted into the formula, the equation reduces to

$$
\mathrm{PE} \%=60.7 \sqrt{\frac{1}{n}-3.8\left[\frac{1}{L}+\frac{10}{3 L^{2}}\right]} \text {. }
$$

This relation is presented graphically in Figure 5 . The basic question remains as to what $\mathrm{PE}$ represents the best balance of accuracy and effort.

As an examination of the graph shows, greater accuracy requires more transects. For example, a 100-foot long deposit attains a PE\% of $15 \%$ with 10 transects, but 15 transects are required if the $P E \%$ is to be reduced to $10 \%$. Seven transects would give a $20 \%$ probable error for the same length.

For most regional resource valuations, a relative probable error of about 18 to $20 \%$ is usually acceptable. In development-type reserve estimates, at a mine site for example, a smaller PE\% of $5 \%$ would be desirable. The more marginal the deposit is, the greater will be the accuracy needed to guarantee against loss if the property is mined. Everything considered, it appeared reasonable to design the Sierra MadreMedicine Bow uranlum estimates for a $P E \%=20 \%$.

The value of the length $L$ depends on whether an estimate for the local area is desired, or a regional estimate is being made. For this study we looked only at the three favorable sites which contained the high- 


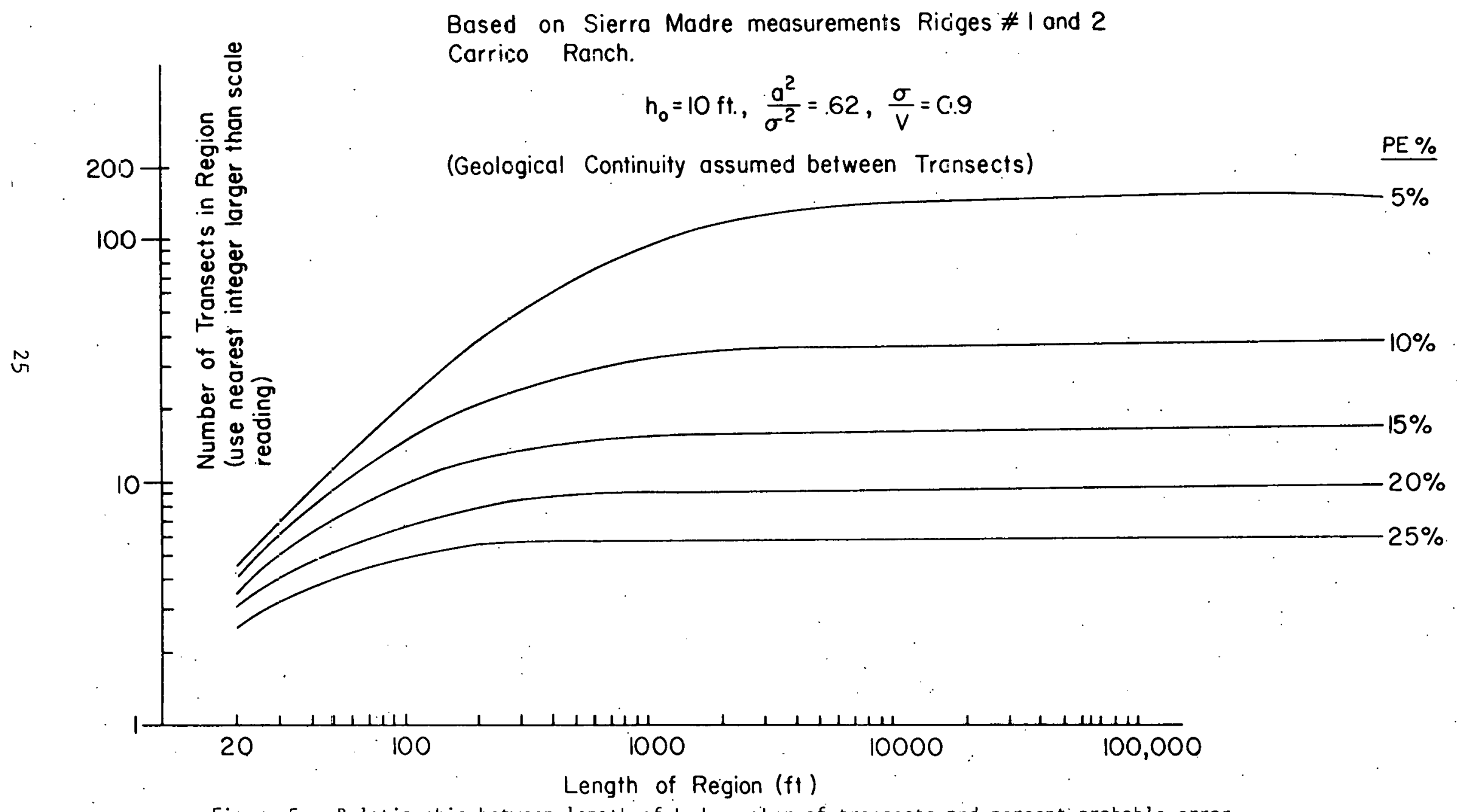

Figure 5. Relationship between length of bed, number of transects and percent probable error. 
est grade materials (Onemile Creek, Threemile Creek, and Carrico Ranch areas). Outcrops in high grade material will use an $L$ of approximately 400 feet as the length of the outcrop, although several nearby outcrops may be linked if the outcrops are too short. The number of transects needed to give a $P E \%=20 \%$ for that $L$ is then 9 , as read from the graph.

Transect sampling was carried out as follows. Spectrometer readings of total gamma radiation were made more or less continuously along the transect, to locate "hot" layers. These readings were not recorded individually, although an overali summary was written for general and special features present. Readings were recorded for extra-hot zones.

Attempts were made to sample all hot layers encountered. Thin layers, less than 8 inches, were sampled with one or two chunks of rock. Thicker layers were sampled at 3 or 4 places through the bed. The intent here was to approximate a channel sample of the "hot" bed as closely as possible. The samples for a single "hot" bed were bagged together and analyzed as a single combined sample which yielded an estimate of the average uranium in that bed at that location. Country rock, with radioactivity fairly uniform, was sampled at 2 or 3 locations along the transect.

\section{Drill Core Sampling Plan}

Assays of samples taken from drill core serve two important purposes. The assay values may be used to estimate reserves and they may be studied to lead to a more complete understanding of the geological processes present in the deposit. The sampling plan designed here was primarily directed to the first purpose - that of estimating reserves. 
However, modifications have been introduced to allow the sampling plan to satisfy the second purpose reasonably well.

The accumulation for a core is defined as the integral of the ore value along the core. Let $V(z)$ be the uranium concentration at vertical position $z$.

$$
\text { Accumulation. }=\int_{z_{\text {top }}}^{z_{\text {bot tom }}} v(z) d z \text {. }
$$

Then the integral of the accumulation over the horizontal area of the deposit, after division by the volume of the deposit, gives the average value of the deposit.

Various elaborations, such as making the computations in zones or introducing statistical techniques like kriging, may be incorporated into the analysis. The procedure outlined above, however, illustrates the essential aspects of the method. To achieve this target, a three step procedure was used.

1. The core was scanned continuously with a spectrometer to locate 'hot'zones accurately. The spectrometer scan was done in such a way as to give a continuous run of readings. This scan was confirmed by down-hole spectrometer measurements in the drill hole. As an operational definition, it appeared reasonable to define a "hot" zone as an interval of readings where the total gamma count is $20 \%$ greater than the nearby country rock average count. The location and length of the "hot" zones were carefully recorded for the collection of assay samples. 
2. The "hot" zones were sampled for assay in intervals not exceeding one foot or the length of the "hot" zone, whichever' was less. A lengthwise cut of the core, of uniform cross-section, running the full length of the interval, was crushed and split for the assay. If the "hot" zone was longer than one foot, several intervals were needed to cover the whole zone. The essential point is that the entire "hot" zone interval was covered by these interval samples.

In addition it was desirable to collect "point" samples at the bottom, middle, and top of the hot zones if the zones were of substantial thickness. As guided by geological judgment, it was desirable to sample any additional locations along the core where signi-. ficant changes appeared to be present. These samples were largely intended to assist in geological interpretation, rather than reserve estimation.

3. The "warm" country rock surrounding the hot zones was sampled approximately every twenty-five feet. The root-mean-square percentage error in using a 25 foot sampling interval to estimate the country rock accumulation was found to be about $1 \%$. Sampling at 80 foot intervals led to a $2.4 \%$ R.M.S. error. The 25 -foot interval was suggested because it also offered some protection against unforeseen trends or variations in the uranium content of the country rock. It also has - quitc acceptable accuracy. Since the overall accuracy of reserve estimation was planned for about $20 \%$, the $1 \%$ error in vertical accumulation is quite satisfactory in not interfering with the horizontal. (areal) outcrop sampling directed at achieving the $20 \%$ accuracy. The samples for assay taken every 25 feet were point samples 
(not interval or channel samples). In addition, extra samples were collected at locations along the core where the geologist believed that significant changes occur in the country rock. 
THIS PAGE

WAS INTENTIONALLY

LEFT BLANK 


\section{OUTLINE OF GEOSTATISTICAL METHODOLOGY AND THE STATISTICAL PARAMETERS OF THE DEPOSIT}

\section{The Variogram}

The basic characterization of spatial persistence used in mining geostatistics is the variogram function, sometimes called the semivariogram. It is a function of distance and direction of the separation ur "lay" between two ore grades in the deposit. More specifically, the variogram, $\gamma(\underline{h})$, is defined as one-half of the average of the squareddifference between ore grades separated by the vector $\underline{h}$. The difference between grades for each pair is squared. One-half of the average of these squared-differences would give an estimate of the variogram at lag $\underline{h}$. This would have to be repeated at a number of different lag values to develop a clear delineation of $\gamma(\underline{h})$ for all $\underline{h}$ values. If the ore assays are established on some regular grid, the variogram can be estimated using neighboring pairs of grades for the shortest lag. Pairs separated by two grid spacing can be used for the next larger lay ur averaging. Then 3 grid separations can be used, and so forth.

If the variogram does not vary with direction of lag but only depends on the distance of separation, the random field of data is said to be "isotropic." The variogram is then a function of the length, $h$, not the vector, $\underline{\text { h. }}$.

For the uranium-bearing pebble conglomerates, the radioactivity appears to be isotropic within the mineable surface. Hence, the further 
discussion will be restricted to this case. The theorems derived in Appendix A, however, are more general and are based on an anisotropic variogram with elliptical zone of influence over the mineable surface.

A typical isotropic variogram might have the shape shown in Figure 6. As the value of $h$ becomes small, spatial persistence makes the grades increasingly similar to each other, and the $\gamma(h)$ value approaches zero. The squared difference between grades of sampleg elose together is small. As $h$ gets large, the grade at one end of the separation becomes more and more unrelated to the grade at the other end. The squared difference gets larger. At some distance, called the zone of influence, $h_{0}$, the two grades are uncorrelated with each other and the average squared distance stays at about the same value for all larger $h$. It can be shown that for statistically stationary random fields of ore. grade, the variogram will: level off at a value equal to the variance, $\sigma^{2}$, of the grade. Finally, one often encounters variograms with the appearance of Figure 7. If the $\gamma(h)$ values at the shorter lags are extrapolated to zero, the line of extrapolation does not pass through zero, but gives $a^{2}>0$ where

$$
a^{2}=\lim _{h \rightarrow 0} Y(h) .
$$

This means that there are abrupt changes in grade on a local scale (fractures, rich veins in waste, etc.). Thus, the average squared difference stays large even for spatial separations very small.

The variogram often motivates interesting geological conjectures concerning the deposit. Some other typical cases are given in Figure 8 . 


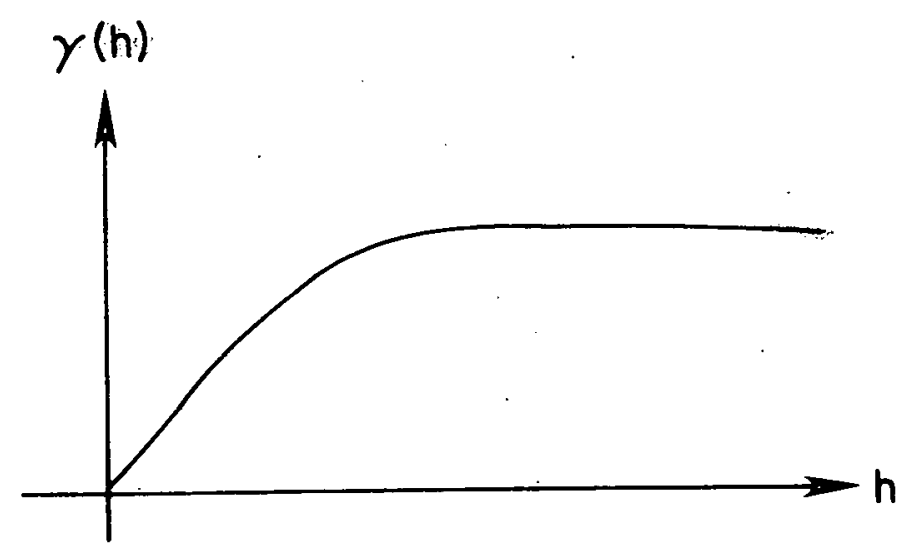

Figure 6. A typical isotropic variogram.

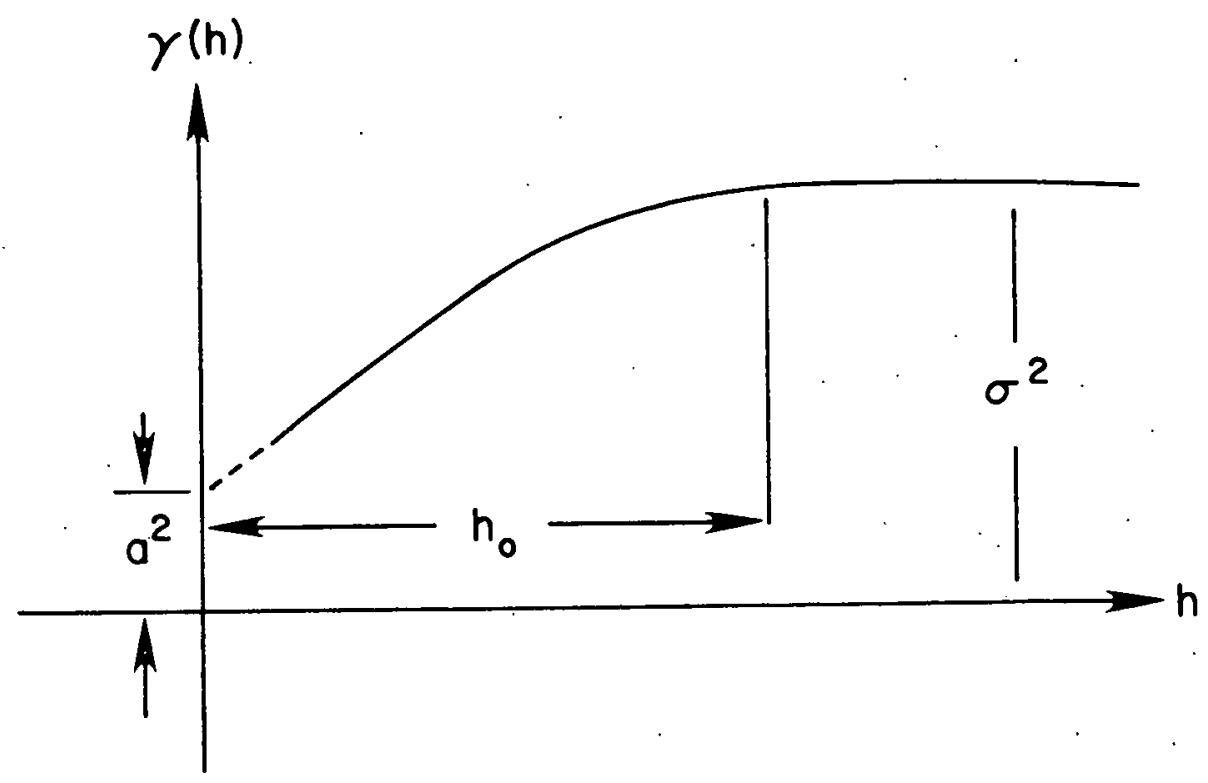

Figure 7. Typical variogram with variance, $\sigma^{2}$; zone of influence, $h_{0}$; and nugget effect, $a^{2}$. 


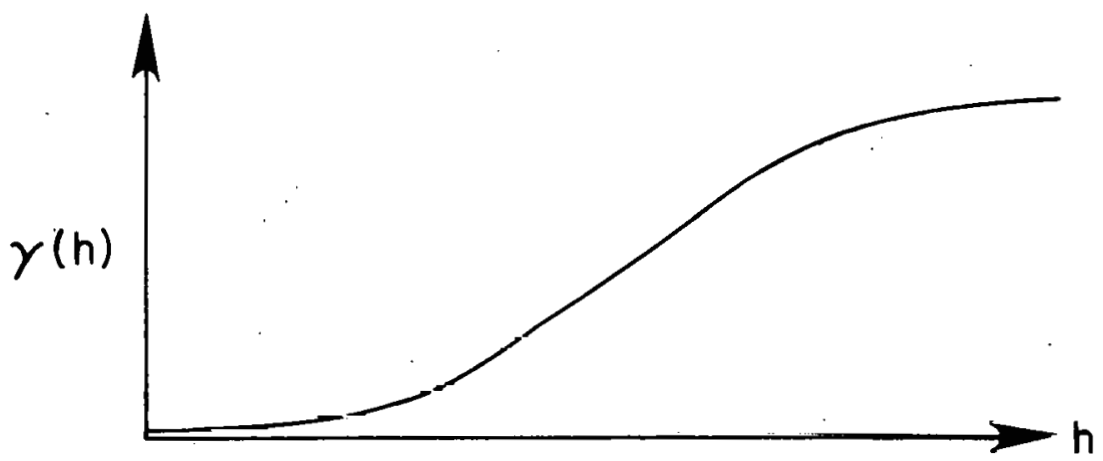

A.

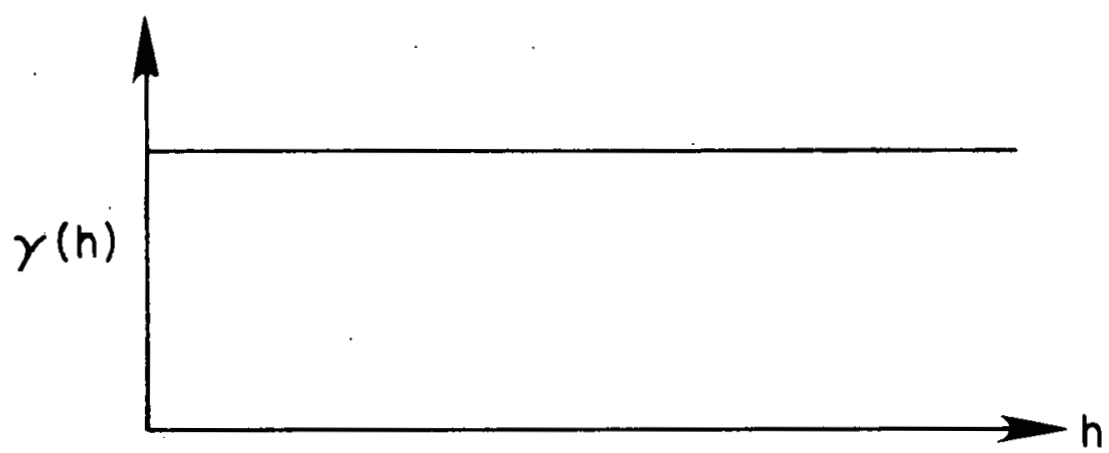

B.

Figure 8. Theoretical Variograms (A) strong spacial persistence (large $h_{0}$ ) and (B) cumplete independence between grades even at small spacings. 
Variograms estimated from actual data have sample randomness and a much more jagged appearance than the idealized figures presented here. Some examples of actual variograms from the uranium data are shown below.

Another measure of spatial persistence useful in geostatistics is the covariance function. It can be defined as $C(h)$, where

$$
c(h)=\sigma^{2}-\gamma(h)
$$

for statistically stationary, isotropic random ore deposits.

\section{Kriged Estimates}

The gcostatistisal pronredure of kriqing (David, 1977; Journel and Huljbregts, 1978) can be based on ei ther the covariance function or the variogram. In the following, the covariance function will be used. If all assay values are of equal important to the determination of the average grade in some depth zone, a reasonable estimate would be the arithmetic average of the assays. In mathematical terms, if $V\left(x_{i}\right)$ is the assay value at location $x_{i}$, and there are $n$ assays available making an estimate of average grade for a zone $B$, then

$$
\hat{\bar{v}}_{B}=\frac{1}{n} \sum_{i=1}^{n} v\left(x_{i}\right)
$$

where $\hat{\bar{V}}_{B}$ is the estimated average grade for the zone.

If all of the assays are not equally important to the determination of the average grade of zone B (for example, some assays may be within the zone and others may be some distance away), then a weighted average of the form 


$$
\begin{array}{r}
\hat{\bar{v}}_{B}=\sum_{i=1}^{n} a_{i} v\left(x_{i}\right), \\
\text { where } \quad \sum_{i=1}^{n} a_{i}=1.0
\end{array}
$$

may be more reasonable. For example, nearby values may be weighted more than those far away.

This raises the question, are therc systcmotic procedurcs for determining the optimai or "best" choices of the weights, $a_{i}$. The answer is yes and the procedure is found to depend on the covariance function. The measure of optimality used is that the best weights, $\hat{a}$, are those which minimize the expected square difference between the actual average grade $\bar{V}_{B}$ and the estimate of that value, $\hat{\bar{V}}_{B}$. The mathematical procedure for deriving these optimal weights is derived in theorem A-5 of Appendix A. Essentially the procedure reduces to the solution of a system of simultaneous equations whose coefficients and other constants are determined from the covariance function. The general technique is called kriging.

In the closely spaced sample collection of the production or development phases of mineral development, many samples are within a zone of influence of each other and the system of equations may become difficult to solve. However, in reconnaissance sampling the reverse is true. All samples are usually more than a zone of influence apart and the system of equations reduces to the very simple explicit solutions given in theorem A-6 of Appendix A. In fact if the zone of influence is small and the sample spacing is large; the weights are well approximated by $1 / n$ and 


$$
\hat{\bar{V}}_{B}=\frac{1}{n} \sum_{i=1}^{n} V\left(x_{i}\right)
$$

with error variance bounded by

$$
\sigma_{E}^{2}=\text { Expected value of }\left(\hat{\bar{V}}_{B}-\bar{V}_{B}\right)^{2} \leq \frac{\sigma^{2}}{n}+C_{B B} \text {, }
$$

where $C_{B B}$ can be computed from the geometry of the zone $B$ and the covariance function. In particular, if the variogram is of the simple transitive isotropic form (definition $A-1$ with very small $s(\theta)$ and $\left.a=b=h_{\odot}\right)$, a convenient. upper bound for $\sigma_{E}^{2}$ is

$$
\sigma_{E}^{2} \leq \frac{\sigma^{2}}{n}+\frac{\pi h_{O}^{2}\left(\sigma^{2}-a^{2}\right)}{3 B}
$$

where $B$ denotes the area of zone $B$ on the mineable surface.

\section{The Sampling Relation in Figure 5}

The equation used in Figure 5 was an even simpler version of the relation for $\sigma_{E}^{2}$. All the equations can be simplified to one-dimensional space (i.e., samples along the strike of the outcrop). The simple transitive variogram becomes

$$
\gamma(h)= \begin{cases}a^{2}+\left(\sigma^{2}-a^{2}\right)|h| / h_{0}, & \text { if }|h| \leq h_{0} \\ \sigma^{2}, & \text { if }|h|>h_{0} .\end{cases}
$$

and the covariance function is

$$
c(h)= \begin{cases}\left(\sigma^{2}-a^{2}\right)\left(1-|h| / h_{0}\right), & \text { if }|h| \leq h_{0} \\ 0, & \text { if }|h|>h_{0} .\end{cases}
$$

Under the conditions that all samples are more than a zone of influence apart and are collected at an interior point of zone B more than a zone 
of influence from the nearest boundary of $B$, the expressions $C_{B B}$ and $C_{B i}$ in theorem A-5 may be explicitly evaluated as

$$
\begin{aligned}
C_{B i} & =\frac{1}{L} \int_{B} c\left(x-x_{i}\right) d x \\
& =\left(\sigma^{2}-a^{2}\right) h_{O} / L
\end{aligned}
$$

and

$$
\begin{aligned}
C_{B B} & =\frac{1}{L^{2}} \int_{B} \int_{B} c\left(x-x^{\prime}\right) d x d x^{\prime} \\
& =\left(\sigma^{2}-a^{2}\right)\left(h_{0} / L\right)\left(1-h_{0} / 3 L\right)
\end{aligned}
$$

where $L$ is the length of the one-dimensional zone B. For this case, the values of $a_{i}$ and $\mu$ resulting from the solution of the system of equations in theorem $A-5$ are

$$
\begin{aligned}
& \hat{a}_{i}=1 / n \\
& \hat{\mu}=\left(\sigma^{2}-a^{2}\right) h_{0} / L-\sigma^{2} / n .
\end{aligned}
$$

Hence the expression for $\sigma_{E}^{2}$ becomes

$$
\begin{aligned}
\sigma_{E}^{2} & =c_{B B}-\sum_{i=1}^{n} \hat{a}_{i} c_{B i}-\hat{u} \\
& =\frac{\sigma^{2}}{n}+\left(\sigma^{2}-a^{2}\right)\left(h_{o} / L\right)\left(1-h_{0} / 3 L\right)-2\left(\sigma^{2}-a^{2}\right)\left(h_{0} / L\right) .
\end{aligned}
$$

Since the probable error is

$$
P E=.6745 \sigma_{E},
$$

it follows that the probable error in $\%$ is given by

$$
\begin{aligned}
P E \% & =67.45 \sigma_{E} \hat{\bar{V}} \\
& =67.45(\sigma / \hat{\bar{V}})\left[1 / n-\left(1-a^{2} / \sigma^{2}\right)\left(h_{0} / L+h_{0}^{2} / 3 L^{2}\right)\right]^{1 / 2} .
\end{aligned}
$$


If $h_{0}=10$ feet, $\sigma / \bar{V}=0.9$, and $a^{2} / \sigma^{2}=0.62$ as the preliminary radioactivity sampling seemed to indicate, the probable error becomes

$$
P E \%=60.7\left[1 / n-3.8\left(1 / L+10 / 3 L^{2}\right)\right]^{1 / 2} \text {. }
$$

This equation was used to develop the graph in Figure 5 .

The graph served only as a guide for sampling purposes. Subsequently more extensive data arrays were used to refine and adjust the variogram parameters. For example, it was decided to use in the probable error computations of the final resource estimate, the values $a^{2}=0$ and $h_{0}=60$ feet since these gave conservative bounds for the error. Almost all of the estimated variograms gave values which actually predict smaller probable errors than $a^{2}=0$ and $h_{0}=60$ feet. Lognormality of $\mathrm{U}_{3} \mathrm{O}_{8}$ and $\mathrm{ThO}_{2}$

The correction of the near-surface tonnage estimates to produce leached uranium endowments, depends critically on the probability law for the population of the larger $\mathrm{U}_{3} \mathrm{O}_{8}$ values. Previously published investigations have usually found that uranium grade is lognormal. It appeared reasonable to expect lognormal behavior for the Medicine Bow and Sierra Madre deposits.

The grade values which enter the computations consist of the thickness-weighted averages of the grade along each outcrop transect or drill hole as it pierces the mineable surface. The averages are only

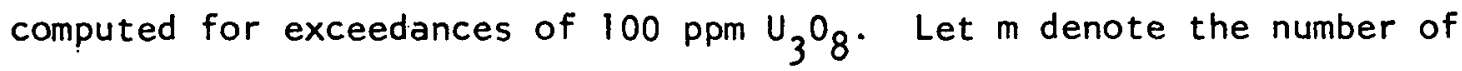
the transects or drill holes which fail to encounter an (unleached) $U_{3} \mathrm{O}_{8}$ value exceeding $100 \mathrm{ppm}$. If there are $n$ transects and drill 
holes, then $(n-m)$ of the piercements of the mineable surface encounter exceedances of $100 \mathrm{ppm}$. Let

$$
\text { , } \quad \ln U_{m+1} \leq \ln U_{m+2} \leq \ln U_{m+3} \leq \ldots \leq \ln U_{n}
$$

represent the averages of the logarithm of the grade for those layers exceeding $100 \mathrm{ppm}$ unleached. The fraction of the piercements with value less than or equal to $\ln U_{r}$ is $r / n$. This is sometimes called the empirical distribution function,

$$
\hat{F}_{E}\left(U_{k}\right)=r / n \text {, for } m<r \leq n
$$

and is regarded as a prediction of the distribution function for the uranium values when uranium $=U_{r}$. However, this estimate has the defect that

$$
\hat{F}_{E}\left(U_{n}\right)=1.0
$$

and this value cannot be plotted on lognormal probability paper since 1.0 on the probability scale corresponds to $U=\infty$ for these types of probability. This problem can be circumvented in several ways. One of the best is advocated by Gumbel (1954) who points out that if $F(u)$ is the distribution function for the $U$ population, then

$$
\left\{\text { Expected value of } F\left(U_{r}\right)\right\}=r /(n+1) \text {. }
$$

With this plotting formula (i.e. $\left.\ddot{F}_{*}\left(U_{r}\right)=r /(n+1)\right)$, the largest value observed, In $U_{n}$, is plotted versus

$$
\hat{F}_{*}\left(U_{n}\right)=n /(n+1)
$$

on the probability scale. This point can be placed on lognormal paper with no difficulty. 
Thus the procedure used in testing the transect and drill hole accumulated grades for lognormality was as follows. The width-averaged values of the $\ln \mathrm{U}_{3} \mathrm{O}_{8}$ (as corrected approximately to their unleached values) for all exceedances of $100 \mathrm{ppm}$ were ranked in increasing order:

\begin{tabular}{|c|c|c|}
\hline$\stackrel{r}{r a n k}$ & $\begin{array}{l}\text { Average } \\
\text { In U } \mathrm{U}_{3} \mathrm{O}_{8}\end{array}$ & $\hat{\mathrm{F}}_{*}\left(U_{r}\right)=r /(n+1)$ \\
\hline$m+1$ & $\ln U_{m+1}$ & $(m+1) /(n+1)$ \\
\hline$m+2$ & $\ln U_{m+2}$ & $(m+2) /(n+1)$ \\
\hline $\mathrm{m} 13$ & $\ln U_{m+3}$ & $(m+3) /(n+1)$ \\
\hline - & - & • \\
\hline • & - & - \\
\hline - & - & $\cdot$ \\
\hline$n$ & $\ln U_{n}$ & $n /(n+1)$. \\
\hline
\end{tabular}

If the graph of $\ln U_{r}$ versus $r /(n+1)$, on normal probability paper is approximately a straight line, then the grade accumulations of exceedances of $100 \mathrm{ppm}$ behave approximately like the upper tail of the lognormal.

This pronedure was followed for the Medicine Bow and Sierra Madre $\mathrm{U}_{3} \mathrm{O}_{8}$ and $\mathrm{ThO}_{2}$ values. The resulting graphs are shown in Figure 9 . In each case a straight line appears reasonably consistent with the data. The lognormal parameters, $\mu$ and $\sigma^{2}$, can be estimated from the straight lines by the following conventions

$$
\begin{aligned}
& \hat{\mu}=\text { value of } \operatorname{In} \text { where } p=50 \\
& \hat{\sigma}=\text { (value of In where } p=84.13 \text { ) }-\hat{\mu}, \\
& \text { where } p \text { is } \% \text { probability. }
\end{aligned}
$$


Sierra Madre $\mathrm{U}_{3} \mathrm{O}_{\varepsilon}$

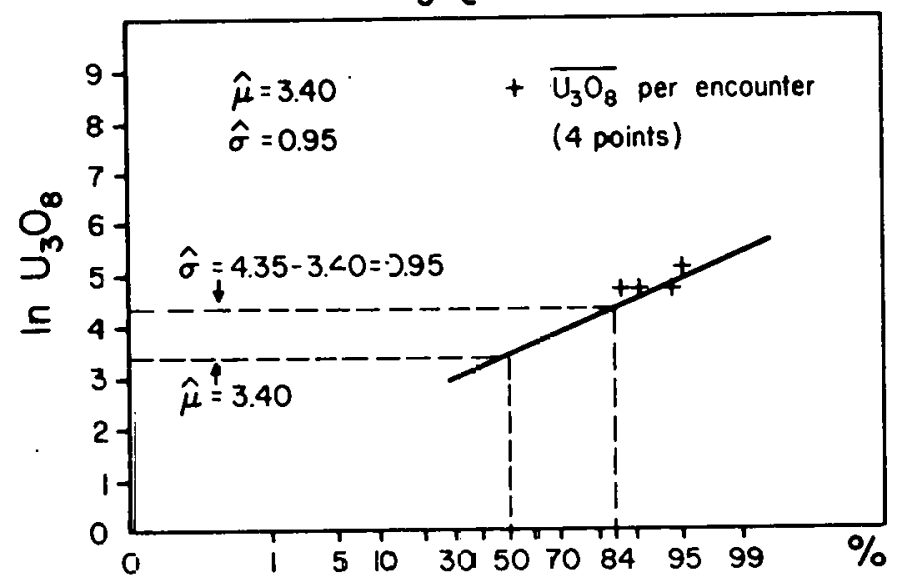

$\stackrel{5}{N}$

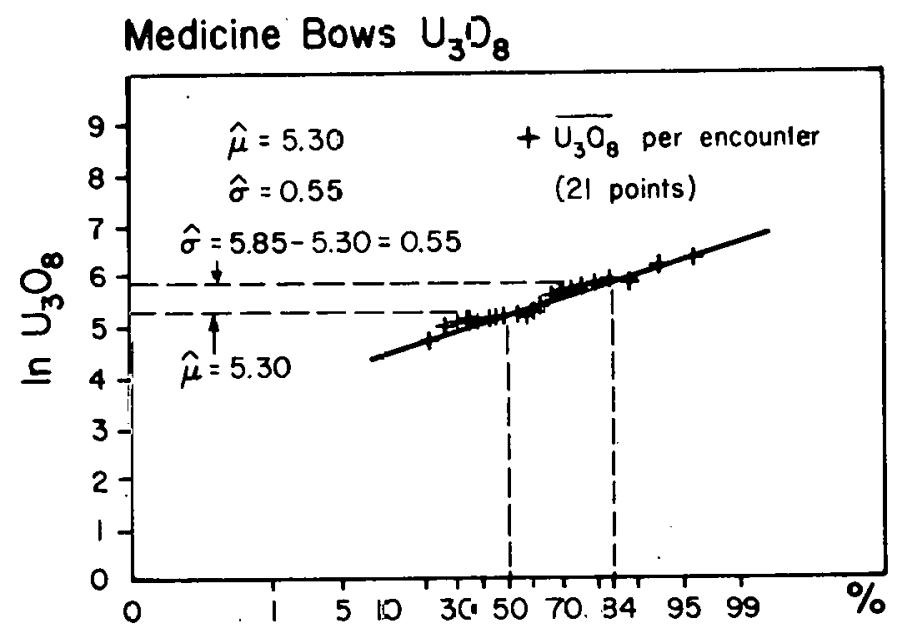

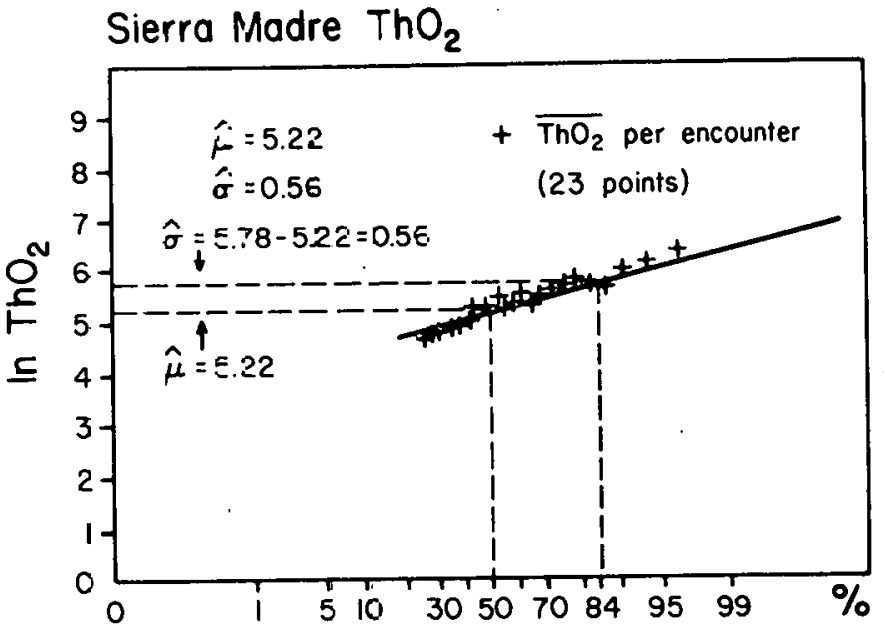

Medicine Bows $\mathrm{ThO}_{2}$

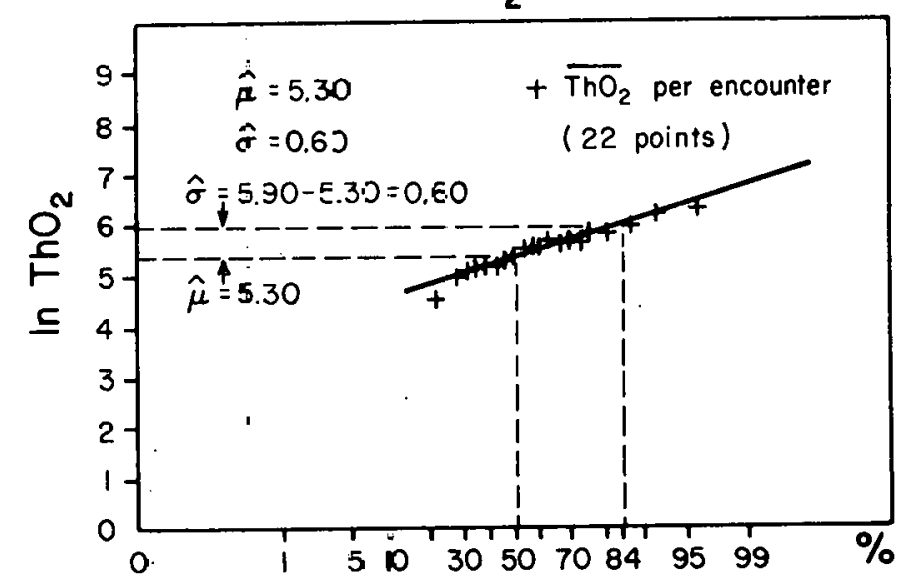

Figure 9. Lognormal probability plots for uranium and thorium, sierra Madre and Medicine Bow Mauntains. 
The predicted values for $\hat{\mu}$ and $\hat{\sigma}$ are $l$ isted with each graph in Figure 9 . These values will be used later in the section on the leaching formulas and associated resource adjustments.

\section{The Variogram Parameters}

As more data was accumulated, additional information became available for computing variogram parameters. The assay values could not be used for this purpose since they were always more than a zone of influence apart. However, additional radioactive count data was collected at close enough spacing to allow the determination of $a^{2} / \sigma^{2}$ and the zone of influence, $h_{0}$. Some examples are shown in Figures 10,11 , and 12. In addition, there were many cases where only upper bounds to the parameters could be determined. A number of such estimates are summarized in Tables 1 and 2. Upper bounds are very relevant, because often they can be used to develop corresponding upper bounds for the probable error. In the resource data analyzed so far, a zone of influence of 60 feet and a nugget effect of 0 appears to give reasonable upper bounds. Actually, the probable errors were computed for both $h_{0}=30$ and $h_{0}=60$ feet with only slight changes in results. Thus, the error analysis is quite insensitive to $h_{0}$ and $a^{2}$ for the range of values in the data studied. 


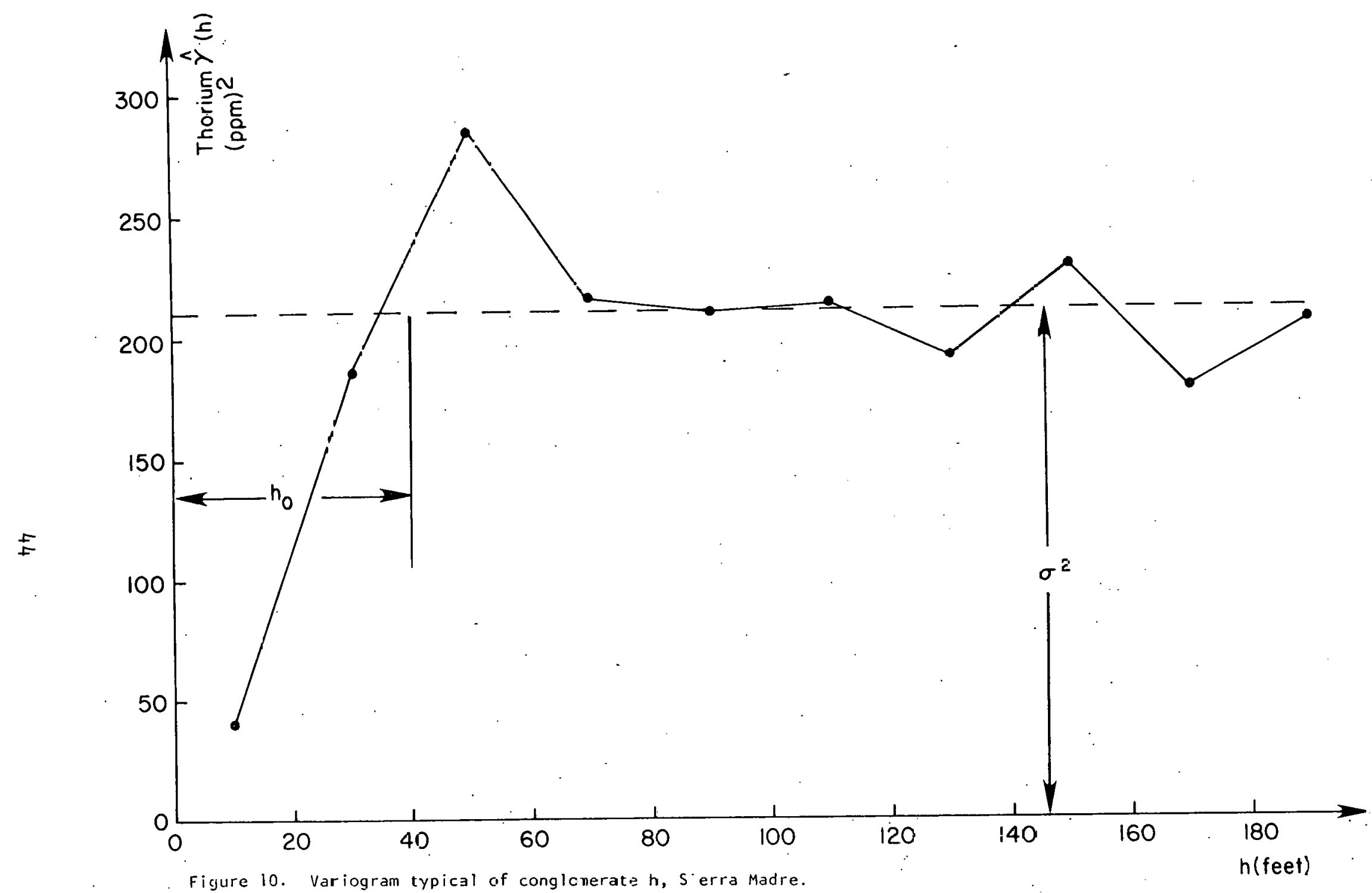

Figure 10. Variogram typical of conglcnerate $h$, S erra Madre. 


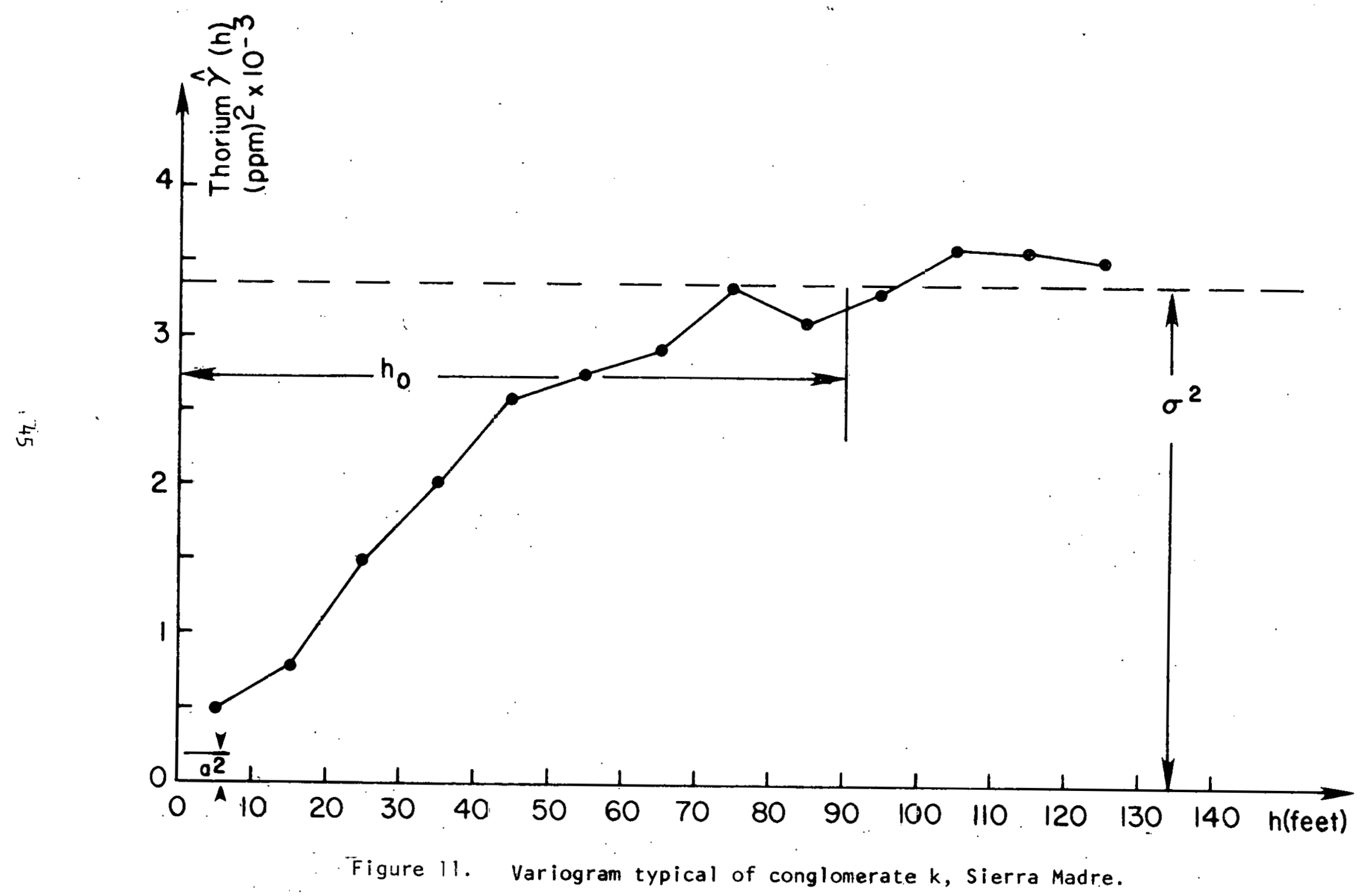




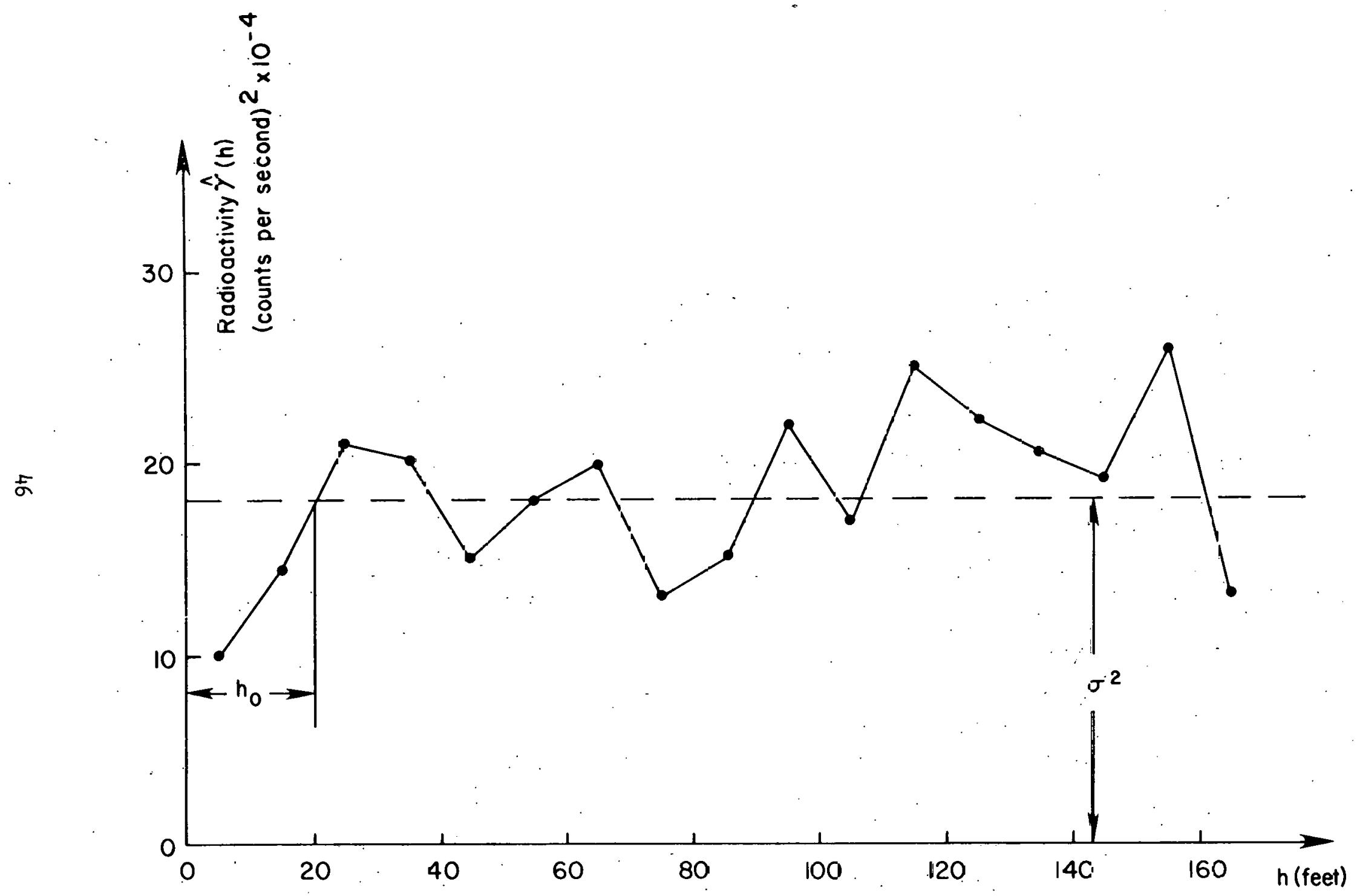

Figure 12. VEriogram typical of Onemile Creek area conglome-ates. 


\begin{tabular}{|c|c|c|c|c|}
\hline Rank & $\begin{array}{r}\text { Zone of i } \\
h_{0} f \\
\text { rank }\end{array}$ & $\begin{array}{l}\text { fluence, } \\
\text { et } \\
\text { d) }\end{array}$ & $\begin{array}{r}\text { nugget-to-vari } \\
\text { ratio a } \\
\text { (ranked) }\end{array}$ & $\begin{array}{l}\text { iance } \\
\sigma^{2}\end{array}$ \\
\hline 1 & 3 & & .0 & \\
\hline 2 & 3 & & .03 & \\
\hline 3 & 5 & & .27 & \\
\hline 4 & 5 & & .28 & \\
\hline 5 & 6 & & .55 & \\
\hline 6 & 10 & & .61 & \\
\hline 7 & & median value & .62 & $\mid \begin{array}{r}\text { median } \\
\text { value }\end{array}$ \\
\hline 8 & 14 & & .63 & \\
\hline 9 & 26 & & .79 & \\
\hline 10 & 36 & & .80 & \\
\hline 11 & 45 & & .81 & \\
\hline 12 & 75 & & .91 & \\
\hline 13 & 117 & & .99 & 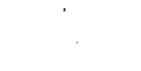 \\
\hline
\end{tabular}

Table 1. Variogram parameters for radioactivity, Carrico Ranch, Sierra Madre. (Note: parameters are ranked separately in increasing size. Average variance of count $=55000 \mathrm{ppm}^{2}$ ). 


\begin{tabular}{|c|c|c|c|c|c|c|}
\hline & & Conglo & merate & $\begin{array}{c}\text { Zone of } \\
\text { influence } \\
\text { ( } \mathrm{ft})\end{array}$ & Sill Value & $\begin{array}{l}\text { Nugget } \\
\text { effect }\end{array}$ \\
\hline \multirow{6}{*}{ 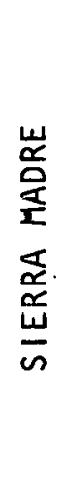 } & \multirow{6}{*}{ 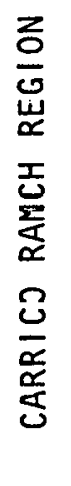 } & & G & shows trend & & \\
\hline & & & $H$ & 40 & $220(\mathrm{ppmTh})^{2}$ & $1.0(\mathrm{ppmTh})^{2}$ \\
\hline & & & 1 & 40 & $2200(\mathrm{ppmTh})^{2}$ & $0.0(\mathrm{ppmTh})^{2}$ \\
\hline & & & $J$ & shows trend & & \\
\hline & & & K & 90 & $3350(\mathrm{ppmTh})^{2}$ & $200(p p m T h)^{2}$ \\
\hline & & & $\mathbf{L}$ & 25 & $350(\mathrm{ppmTh})^{2}$ & $100(\mathrm{ppmTh})^{2}$ \\
\hline & $z$ & Case & 1 & $<10$ & & \\
\hline & ज出. & & 2 & 40 & $35000(c p s)^{2}$ & $0(c p s)^{2}$ \\
\hline 3 & 弟 & & 3 & $<10$ & & \\
\hline$\omega$ & 品 & & 4 & $<10$ & & \\
\hline$\frac{\Sigma}{\underline{v}}$ & $\stackrel{w}{\Sigma}$ & & 5 & 30 & $80000(c p s)^{2}$ & $0(c p s)^{2}$ \\
\hline 岕 & 峁 & & 6 & 20 & $18000(\mathrm{cps})^{2}$ & $6000(\mathrm{cps})^{2}$ \\
\hline & & & 7 & $<10$ & & \\
\hline
\end{tabular}

Table 2. Variogram parameters values for data from various portions ur Llie dieas in the siema Madre and Medicine Bow Mountaina 


\section{PREDICTION EQUATIONS FOR LEACHING}

It appeared reasonable to assume that (1) below some particular depth, the uranlum and thorium maintained some fixed functional relation with each other, and (2) above that depth the functional relation required that depth be introduced as an additional variable.

Multivariate stepwise regression was used to search for the critical depth and for the functional relationships. Calculations were made for $\ln U$ and $\ln$ Th as well as $U$ and Th as measured. The logarithms of the assay values gave substantially better curve fits. After much trial-and-error, the following basic equation was determined to best represent the general features of the relation between in $U$, in Th, and depth, d:

$$
\begin{aligned}
\ln U & =\left(a_{0}+a_{1} e^{-c d}+a_{2} e^{-2 c d}+a_{3} e^{-3 c d}\right) \\
& +\left(b_{0}+b_{1} e^{-c d}+b_{2} e^{-2 c d}+b_{3} e^{-3 c d}\right) \ln T h \\
& + \text { random error. }
\end{aligned}
$$

This basically assumes that at any depth, there is a linear relation between In $U$ and In Th. However, the intercept and slope of the linear relation are a cubic polynomial of the variable exp(-cd). This allows considerable freedom for the curve to follow the data as it varies with depth. Also, by choosing various values of $c$, the leaching could be made to reach either great depths or only affect very shallow portions of the deposit. 
The general method of analysis consisted of fixing a value of $c$, and then determining the best coefficients $\left(a_{0}, a_{1}, a_{2}, a_{3}, b_{0}, b_{1}, b_{2}\right.$, $b_{3}$ ) to fit the data by stepwise-multiple regression. The goodness-offit, as measured by the fraction of scatter "explained"' by the curve fit (a quantity called $R^{2}$ in statistical parlance) was then noted for that $c$ value. This was done for many different c values and a graph of $R^{2}$ versus $c$ was prepared. The value of $c$ at the maximum $R^{2}$ would then be judged as the value most consistent with the data. Based on the $R^{2}$ criterion, the value $c=.03$ was chosen for both the Sierra Madre and the Medicine Bow Areas. Let $d_{0}$ be the depth at which the variable $\exp (-c d)$ dies off to one percent of what it is at $d=0$. Then $d_{0}$ would be the solution to

$$
\begin{aligned}
& e^{-.03 d_{0}}=.01 \\
& \text { or } \\
& d_{0}=154 \text { feet. }
\end{aligned}
$$

Thus, the $c=.03$ value implies that the leaching is negligible below $d=154$ feet. The functional relations, for $d>154$ feet would approximately be

$$
\ln U=a_{0}+b_{0} \ln T h+\text { error. }
$$

With $c=.03$, the stepwise regression gave quite adequate curve fits with the formulas:

\section{Sicrro Madre}

$$
\begin{aligned}
& \ln U=\left(-.573+.158 \mathrm{e}^{-.09 d}\right) \\
& \quad+\left(.738-1.050 \mathrm{e}^{-.03 d}+.906 \mathrm{e}^{-.06 \mathrm{~d}}\right) \ln \mathrm{Th} \\
& \text { (standard deviation of error of fit }=.717) ;
\end{aligned}
$$




\section{Medicine Bow}

$$
\begin{aligned}
\ln U= & \left(1.608-9.786 \mathrm{e}^{-.03 d}+8.471 \mathrm{e}^{-.09 d}\right) \\
& +\left(.663-.0947 \mathrm{e}^{-.03 d}\right) \ln \mathrm{Th} \\
& \text { (standard deviation of error of fit }=.804) .
\end{aligned}
$$

In both equations, the regression explained about 60 percent of the scatter. Thus the equations represent reasonably good trend lines, but there is still substantial scatter ( 40 percent) about the trend. It should be clearly noted that these equations do not function as prediction equations giving the $\ln U$ value for a particular sample as a function of the in Th and depth for that sample. Rather they establish the surface or trend about which the data scatter.

The equations at substantial depth (>154 feet or so) reduce to the relations for no leaching of:

Sierra Madre $(d=\infty)$

$\ln U=-.573+.738 \ln T h$

and

Medicine Bow $(d-\infty)$

$\ln U=1.608+.663 \ln$ Th.

These equations can be manipulated to the more conventional form of the uranium to thorium ratio of:

$$
\begin{aligned}
& \text { Slerra Madre }(d=\infty) \\
& \begin{aligned}
(U / \mathrm{Th}) & =\mathrm{e}^{-.573} \mathrm{Th}^{-.262} \\
& =.56 \mathrm{Th}^{-.26}
\end{aligned}
\end{aligned}
$$

and 


$$
\begin{aligned}
& \text { Medicine Bow }(d=\infty) \\
& (U / T h)=e^{1.608} \mathrm{Th}^{-.337}
\end{aligned}
$$

This result was somewhat surprising. The exponent on thorium is quite similar for the two areas (on the order of -.3 ), but the multiplier is nine times larger in the Medicine Bow area than in the Sierra Madre. It is conjectured that this difference is probably due to the different ages of the formations and some substantial associated depositional or mineralogical differences. Mineralogical analyses performed by Houston (and reported in Volume 1 , this report) indicate that, although the Medicine Bow deposits have several mineral phases bearing both uranium and thorium, the Sierra Madre units lack any major uranium-bearing minerals.

The relation clearly delineates the observed relationship in the assays that most of the radioactivity in the Carrico Ranch area (Sierra Madre) is due to thorium content, while the Medicine Bow areas have more uranium for the same level of thorium.

Tha amount of leaching at any depth, as stated in terms of difference in logarithms of unleached uranium and leached uranium follows the trend given by subtracting the shallow or depth-dependent relation from the unleached relation holding at depth.

\section{Sierra Madre}

$$
\begin{aligned}
& \log \text { increment for leaching }=-.158 \mathrm{e}^{-.09 d} \\
& +\left(1.050 \mathrm{e}^{-.03 d}-.906 \mathrm{e}^{-.06 \mathrm{~d}}\right) \ln \mathrm{Th}
\end{aligned}
$$




\section{Medicine Bow}

$$
\begin{aligned}
& \log \text { increment for leaching }=+9.786 \mathrm{e}^{-.03 d}-8.471 \mathrm{e}^{-.09 d} \\
& +.0947 \mathrm{e}^{-.03 d} \text { In Th. }
\end{aligned}
$$

Along the outcrop transects where the major portion of assay data used in the resource calculation was obtained, the log increment for leaching (at $d=0$ ) reduces to:

\section{Sierra Madre $(d=0)$}

$\log$ increment for leaching $=-.158+.144 \mathrm{ln}$ Th

Medicine Bow $(d=0)$

$\log$ increment for leaching $=1.315+.0947 \mathrm{ln}$ Th.

Another surprising aspect of the leaching relationships was discovered in the zone between $d=$ zero and $d=30$ feet. In planning the analysis, it was more or less assumed that the leaching would be largest at $d=$ zero and decrease along some curve with increasing depth. The formula used in the curve-fitting permits other behavior, however, if the data requires it. A careful examination of the log increment for leaching shows that for larger values of thorium, the amount of leaching increases with depth for about the first 30 feet or so and then begins to decrease steadily with increasing depth. This happens in both the Sierra Madre and in the Medicine Bow areas. Scatter plots of uranium versus depth show that this is a real behavior and not some peculiarity of the analysis procedure. The values at the surface outcrops are slightly richer on the average than those at shallow depths. However, 
the number of assays in this 10 to 30 foot zone is quite restricted and the main curve behavior is controlled primarily by the average surface values ( $d=$ zero) and the trend of the values between 50 feet and 150 feet.

It has been conjectured that the leaching may be strongly affected by the length of time the moisture stays in contact with the ore as it percolatcs downward: Surfacc moisture would move down rapidly al first and then slow down somewhat with increasing depth. Thus, the contact time might be less at $d=$ zero than at $d=20$ feet. However, this is pure speculation.

The leaching adjustments and subsequent tonnage correction procedures were carefully designed so that they would not be sensitive to whether this maximum leaching at 30 feet is actually present or not. The data available at the surface $(d=0)$ and below 50 feet $(d>50$ teet) were quite adequate to provide satisfactory accuracy in the determination of the leaching trend. However, the sparsity of the data for $0<d<50$ feet suggests that the magnitude of the maximum occurring in that interval may, in part, be related to the well known tendency of polynomial curve fits to oscillate to unrealistic extremes where data is absent. As a reasonable approximation to what is probably present, the leaching curves given in equation (43) and (44) were modified for $0<d<50$ feet by replacing the curve with a straight line interpolation between the values at $d=0$ and at $d=50$ feet. The resulting modified curve was averaged over the intervals $(0,100)$ and $(100,200)$ to obtain the leaching 
correction used in the resource computation. This computation vielded the results shown in Table 3. Greater depths were essentially unleached, so the adjustments or corrections were small or zero.
Medicine Bows
$1.406+\frac{0-100}{.0344} \ln \mathrm{Th}$
$.1542+\frac{100-200}{.0015} \ln \mathrm{Th}$
Sierra Madre
$-.0401+.1357 \ln \mathrm{Th}$
$.0162 \ln$ Th

Table 3. Modified averaged log increment for leaching.

The general leaching adjustments proceeded as follows. The log increment for leaching was added to the logarithm of the measured uranium and the value of .165 was added to this to adjust the grade to values for the equivalent logarithm of $U_{3} 0_{8}$. The leaching correction procedure really only affected the top 150 feet of the resource so that in terms of the total deposit only a small portion was involved. However, it allowed the surface outcrop assays to become reasonable predictors of the unleached $U_{3} 0_{8}$ grades holding at depth.

All the assay data, as adjusted to unleached equivalent grade, then could be used to compute accumulations or thickness-averaged grades for those uranium bearing beds with exceedances of $100 \mathrm{ppm}$. These accumulations are tabled in Appendix D. Finally, these accumulated grades were kriged to produce resource estimates in terms of unleached $U_{3} O_{8}$. The exact details of the kriging will be outlined in the next seciton. However, it is appropriate to discuss the tonnage correction used to convert to leached resource estimates in this section because it is controlled in part by the leaching relations.

As discussed previously, the logarithm of the unleached $U_{3} 0_{8}$ accumulations appear to behave according to lngnormal probabilities. This implies that the $\mathrm{U}_{3}{ }^{0} 8$ will also be lognormal. Also, if $\mathrm{B}^{*}$ represents the 
subset of the region $B$ where exceedances of $100 \mathrm{ppm}$ are encountered, then the fraction of $\mathrm{B}^{*}$. with grade exceeding some other value, say $200 \mathrm{ppm}$, can be computed from the lognormal behavior.

For example, as shown in Figure 1.3, let the area under the curve to the right of $\ln , 100$ be area $A$. This would represent the fraction of $B$ with unleached average grade exceeding 100 ppm. The unleached average grade which would become equal to $1.00 \mathrm{ppm}$ after leaching would be obtalned from:

$$
\begin{aligned}
& \text { urleaclied equivelent }=\ln 100+\text { log increment } \\
& \text { of } 100 \mathrm{ppm} \text { leached }
\end{aligned}
$$

for any particular selected depth. This value on the horizontal axis of Figure 13 is schematically indicated by the downward arrow. Let area $A^{*}$ be the area under the lognormal curve to the right of the vertical arrow. The two areas, $A$ and $A^{*}$, can be interpreted, respectively, as the fraction of $B$ with unleached grade greater than 100 ppm and the fraction of $B^{*}$ with leached grade greater than $100 \mathrm{ppm}$. The lognormal curve is characterized by $\hat{\mu}$ (the middle or balance point of the curve) and $\hat{\sigma}$ (the standard deviation parameter). If these values are known, the areas $A$ and $A^{*}$ can be calculated. Then the tonnage correction is the ratio of area $A^{*}$ to area $A$. The basic relation is:

$$
\begin{aligned}
& \begin{array}{l}
\text { fraction of } B^{*} \text { with } \\
\text { leached grade> }>100 \mathrm{ppm}
\end{array} \quad=\begin{array}{l}
\text { tonnage } \\
\text { correction }
\end{array} \times \begin{array}{l}
\text { fraction of } B \\
\text { with equivalent }
\end{array} \\
& \text { un leached grade> } \\
& 100 \mathrm{ppm} \text {. }
\end{aligned}
$$




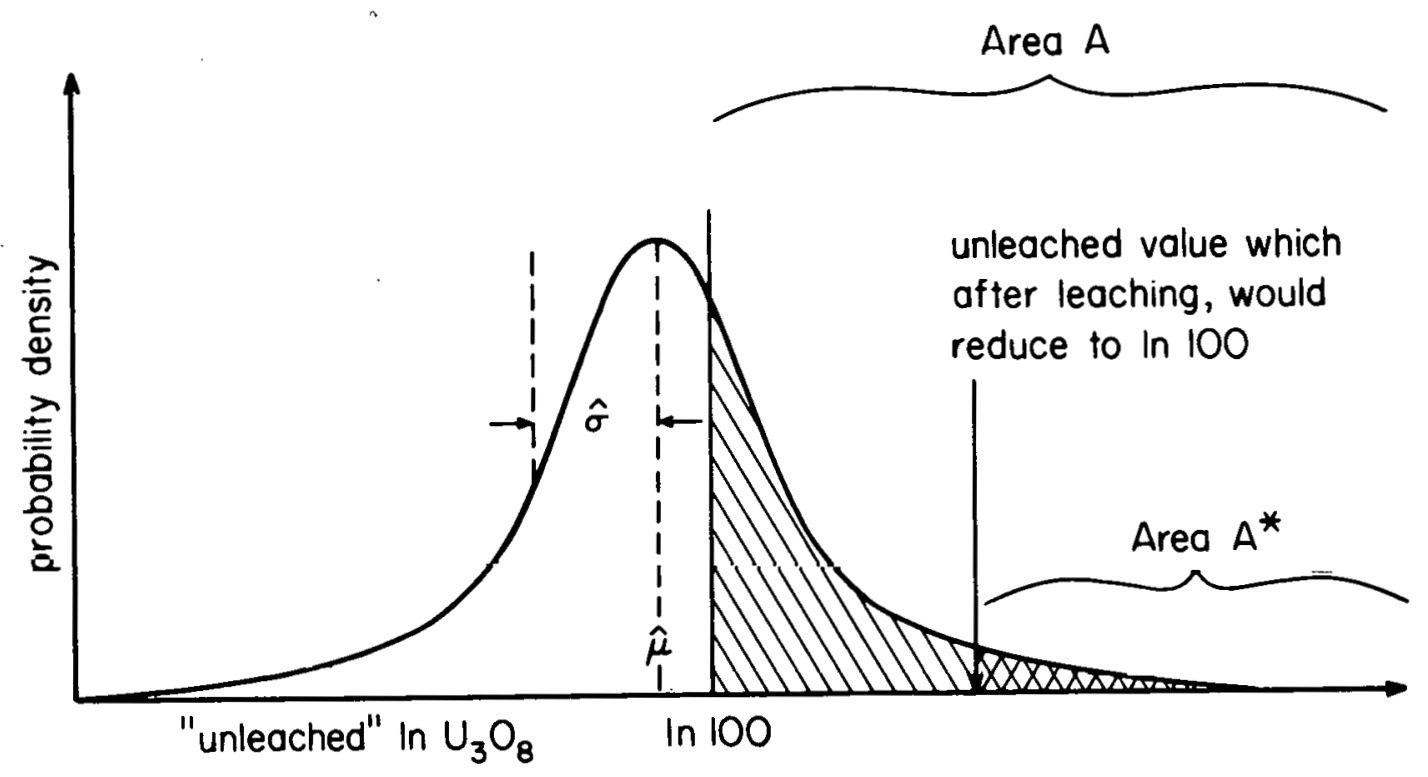

Figure 13. Probability distribution curve illustrating the basis for the tonnage correction. 


\section{THIS PAGE}

\section{WAS INTENTIONALLY LEFT BLANK}


THE RESOURCE DETERMINATION

\section{The Basic Kriging Relation}

The resource determination formula then becomes

\begin{tabular}{|c|c|c|c|c|}
\hline $\begin{array}{l}\text { tons } \mathrm{U}_{3} \mathrm{O}_{8} \\
\text { leached } \\
\text { in a given } \\
\text { depth interal }\end{array}$ & $=$ & $\begin{array}{l}\text { area of } \\
\text { mineable } \\
\text { surface }\end{array}$ & $x$ & $\begin{array}{l}\text { ave rage } \\
\text { thickness }\end{array}$ \\
\hline
\end{tabular}

fraction of mineable surface with un leached grade $>100 \mathrm{ppm}$

$$
\begin{aligned}
& \text { average unleached } \\
& \text { grade for } \\
& \text { exceedances of } \\
& 100 \mathrm{ppm}
\end{aligned} \times \begin{aligned}
& \text { tonnage } \\
& \text { correction } / 11900000 .
\end{aligned}
$$

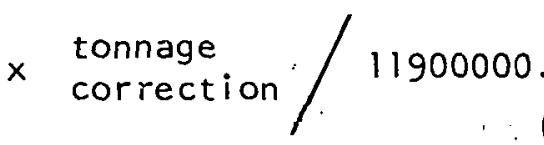

The fraction of the mineable surface with unleached grade>100 ppm is the area of $B^{*}$ divided by the area of $B$. This in turn is approximated by the total number of drill holes and outcrop transects. which encountered beds whose adjusted unleached equivalent grade exceeded 100 ppm, divided by the total number drill holes and transects piercing the mineable surface. For example in the sierra Madre, only two drill holes and two outcrop transects passed through beds with unleached equivalent grade greater than or equal to $100 \mathrm{ppm}$. There were a total of $31 \mathrm{drill}$ holes or transects that encountered the mineable surface. Then the fraction would be $4 / 31$. That is $27 / 31$ of the mineable surface does not experience any exceedances of 100 ppm unleached.

The value $11,900,000$ makes the conversion from ppm to tons of resource. It is based on 11.9 cubic feet per ton, which in turn is the appropriate value for country rock with a specific gravity of 2.7 . 
The assumptions under which this resource formula is equivalent to kriging will now be discussed. Let $V^{*}(\underline{x})$ be the equivalent unleached grade of the deposit at location $\underline{x}\left(x_{1}, x_{2}, x_{3}\right)$. From geological considerations and from the limited data available $V^{*}(\underline{x})$ appears to behave as a stationary random function. Let the adjusted random function $V(\underline{x})$ be defined as

$$
V(\underline{x})=\left[\begin{array}{l}
v^{*}(\underline{x}), \text { if } v^{*}(\underline{x}) \geq 100 \mathrm{ppm} \\
0, \text { otherwise. }
\end{array}\right.
$$

The resource in mathematical terms is

$$
\text { resource }=\text { correction } x \iint_{\text {Deposit }} V(\underline{x}) d \underline{x} \text {, }
$$

where the correction is the depth dependent value which adjusts ppm to tons and makes the tonnage correction for the depth interval involved. In the present study a further modification was introduced in that the inside integral was taken as a perpendicular to the mineable surface and an accumulation was defined as

$$
\begin{aligned}
& A\left(x_{1}, x_{2}\right)= \int_{\text {along } \perp} v(\underline{x}) d x_{3} . \\
& \text { to mineable surface }
\end{aligned}
$$

Then the resource formula becomes the integral over the mineable surface, $B$, of $A\left(x_{1}, x_{2}\right)$. Thus,

$$
\text { resource }=\text { correction } x \int_{B} A\left(x_{1}, x_{2}\right) d x_{1} d x_{2} \text {. }
$$

It was convenient to think in terms of average grade, $\bar{A}\left(x_{1}, x_{2}\right)$, and total thickness of beds with exceedances of $100 \mathrm{ppm}$ unleached 
equivalent, $T\left(x_{1}, x_{2}\right)$. These are mathematically related as

$$
\bar{A}\left(x_{1}, x_{2}\right)=A\left(x_{1}, x_{2}\right) / T\left(x_{1}, x_{2}\right) \text {. }
$$

Thus the resource becomes

$$
\begin{aligned}
\text { resource } & =\text { correction } \times(\text { area of } B) \times\left(\text { area of } B^{*} / \text { area of } B\right) \\
& \times\left(1 \text { /area of } B^{*}\right) \int_{B^{*}} \int T\left(x_{1}, x_{2}\right) \bar{A}\left(x_{1}, x_{2}\right) d x_{1} d x_{2} \cdot
\end{aligned}
$$

The integration can be reduced to being over $B^{*}$ because $\vec{A}\left(x_{1}, x_{2}\right)=0$ for the rest of $B$.

This whole process has reduced the problem to that of estimating the average accumulation over $B^{*}$ :

$$
\begin{aligned}
\text { average accumulation } & =\frac{1}{B *} \cdot \int A\left(x_{1}, x_{2}\right) d x_{1} d x_{2} \\
& =\frac{1}{B} \iint T\left(x_{1}, x_{2}\right) \bar{A}\left(x_{1}, x_{2}\right) d x_{1} d x_{2} .
\end{aligned}
$$

This is precisely what kriging as discussed in Appendix $A$ is designed to estimate. The estimate is a weighted average of $\bar{T} \bar{A}$ over the outcrop and drill hole transects where the weights are determined to minimize the estimate error as shown in Appendix A. Thus the resource est imate becomes

$$
\begin{aligned}
& \text { kriged } \\
& \text { resource }=\text { correction, } \times(\text { area } B) \times \text { area } B * / a r e a ~ B \\
& \text { est imate } \\
& \left.\times \text { (kriged estimate of accumulation over } B^{*}\right) \\
& =\text { correction } 2 \times \text { area } B \times \text { (kriged estimate of } \\
& \text { B). }
\end{aligned}
$$


The resource can be regarded either as a correction times the kriged average over $B^{*}$ or as a different correction times the kridged estimate over $B$.

The kriged accumulations are developed in terms of $U_{3}{ }^{0} 8$ itself, rather than. In $U_{3}{ }^{0}$. Actually, it is acceptable practice to use either approach. Kriging based on $\ln \mathrm{U}_{3} \mathrm{O}_{8}$ is called lognormal kriging. However, this study was based on $U_{3}{ }_{0} 8$ because it was believed that the kriged estimates represent averages over large volumes for this case. The small zones of influence found (certainly less than 100 feet) would indicate that it is equivalent to average a number of independent random quantities. By the central limit theorem of statistics, the average of a number of lognormal variables will be normally distributed, and not lognormal. Thus the probability behavior for the overall resource values can, in this case, be based on regular normality, even though the original input data is lognormal. Actually, the central limit theorem behavior dominates very quickly: The average of even three of four independent lognormal variable will, to a very good appproximation, behave as a normal variable.

\section{Computation of Probable Error}

As shown in the theorem A-6 in Appendix $A$, the variance of estimate error, for the kriged estimate over B, is

$$
\sigma_{B}^{2} \leq \frac{\sigma^{2}}{n}+\pi h_{O}^{2}\left(\sigma^{2}-a^{2}\right) / 3 B \text {. }
$$

The corresponding probable error would be

$$
P E=.6745 \sigma_{B}
$$


and the percentage probable error is

$$
P E \% \cong 67.45 \hat{\sigma}_{B} /(k r i g e d \text { estimate of acccumulation over } B) \text {. }
$$

The probable error is interpreted as the median error due the randomness of grade and thickness as evidenced by the measured data. Thus, it is a statistical error, not a geological uncertainty factor. Judgments concerning geological uncertainty will be discussed later. In order to apply $(58)$ to the resource estimates in the present model, values have to be assigned to the $\sigma^{2}, h_{0}$, and $a^{2}$ constants; the quantities $n$ and $B$, (representing the number of transects or drill hole piercements of the mineable surface, and the mineable surface area of the region which is being averaged, respectively) are known from the sampling plan and the assumed geological model.

The estimate of $\sigma_{B}{ }^{2}$ is quite insensitive to $a^{2}$ and $h_{0}$. Hence it appears reasonable to accept conservative values for these parameters and obtain a reasonable upper bound for $\sigma_{B}{ }^{2}$. If $a^{2}$ is set to zero, the right-hand side of (58) is made as large as it can get relative to the variation of $a^{2}$. From the measured data, it appears quite likely that the overall value of $h_{0}$ is less than $60 \mathrm{ft}$. Thus, $a^{2}=0$ and $h_{0}=60 \mathrm{ft}$. appear to be reasonable choices.

The value of $\sigma^{2}$ is important to the error estimation. In the resource model used, the accumulation, as a function of position on the mineable surface, was taken to be zero if the unleached grade was less than $100 \mathrm{ppm}$, and was assigned the measured value if the unleached grade exceeded or equaled $100 \mathrm{ppm}$. Let $\mathrm{p}$ be defined as the fraction of the mineable surface with unleached grade $\geq 100 \mathrm{ppm}$ (see eg. (49)). 
Then the accumulation is a random function over the mineable surface which is zero on $p$-fraction of the surface and has an average value of mean measured accumulation as determined for those transects or piercements with value $\geq 100 \mathrm{ppm}$. Let $\overline{\mathrm{AcC}}$ denote this last average, and let A $\left(x_{1}, x_{2}\right)$ be the overall random function which is zero when the accumulations drop below $100 \mathrm{ppm}$ (see eq. (52)). Also let $\overline{\text { Acc }^{2}}$ denote the average of the squared values over this same region.

As shown in eqs (49)-(57), the kriged values reported in the resource estimate may be considered as regional averages of $A\left(x_{1}, x_{2}\right)$. Several questions need to be answered before the probable error formulas given earlier can be applied. These are: (1) is $A\left(x_{1}, x_{2}\right)$ stationary? and (2) What is the mean and variance of $A\left(x_{1}, x_{2}\right)$ ?

The accumulations without the $100 \mathrm{ppm}$ cutoff are assumed to be covariance stationary after correction for leaching, with expected lagged product $L\left(h_{1}, h_{2}\right)$, mean $\mu_{0}$ and expected square $s_{0}$.

We note that:

$$
\begin{aligned}
\mu_{A}= & E\left[A\left(x_{1}, x_{2} 0\right]=p \mu_{0},\right. \\
\sigma_{A}^{2}= & E\left[A^{2}\left(x_{1}, x_{2}\right)\right]=p s_{0}, \\
& E\left[A\left(x_{1}, x_{2}\right) A\left(x_{1}+h_{1}, x_{2}+h_{2}\right)\right]=p^{2} L\left(h_{1}, h_{2}\right) .
\end{aligned}
$$

These values do not vary with spatial position, so covariance stationarity is verified. 
It fiollows from the above that reasonable estimates for the mean and variance of $A\left(x_{1}, x_{2}\right)$ are:

$\hat{\mu}_{A}=$ est. mean $A=p \overline{A C C}$,

$\hat{\sigma}_{A}^{2}=$ est. variance $A=p \overline{A c c^{2}}-(\overline{p A c c})^{2}$.

This last quantity is the reasonable data-derived value to use as $\sigma^{2}$ in eq. (58). Thus

$$
P E \% \leq \frac{\left.67.45 \sqrt{\left\{\overline{p A c c^{2}}-(\overline{p A c c})^{2}\right\}\left\{\frac{1}{n}+\pi h_{o}{ }^{2} / 3 B\right.}\right\}}{p \overline{A c C}} .
$$

These probable error values are listed in the resource tables.

Probable errors for intervals and overall estimates are estimated from the same formula. The area $B$ is changed in each case to contain the mineable surface area for that region.

The combination of probable errors from several different (and assumed independent) regions requires a different formula. Let $R_{1}, R_{2}$, $\ldots, R_{n}$ be $n$ regions with mean values $\mu_{1}, \mu_{2}, \ldots, \mu_{n}$ and probable errors $(P E)_{1},(P E)_{2}, \ldots,(P E)_{n}$. Then the square probable error of the overall average is the weighted average of the individual square probable errors.

$$
\text { P.E. of overall average }=\left[\begin{array}{ccc}
n & & (P E)_{i}^{2} \\
\sum_{i=1} & \mu_{i} & \\
\hline \sum_{i=1} & \mu_{i}
\end{array}\right]^{1 / 2}
$$

The Resource Computations

The resource calculations are summarized in Tables 4 to 8 for leached $\mathrm{U}_{3} \mathrm{O}_{8}$. The left column gives the depth interval. The next three 
columns list the area of mineable surface in each depth interval, the leaching correction as based on the value of the integral of the interval, and the tonnage correction. The fifth column summarizes the resource estimates in terms of equivalent unleached tonnage exceeding $100 \mathrm{ppm}$. The tonnage correction is multiplied times this to give the sixth column which is the final estimate of the resource endowment for $\mathrm{U}_{3}{ }^{0} 8$ with grade exceeding $100 \mathrm{ppm}$. This grade represents an estimate of the in-place, leached tonnage of the ore deposit.

The final column of the table gives the percent probable error as based on the conservative choices of $h_{0}=60$ fieet and $a^{2}=0$. The probable errors for the $\mathrm{U}_{3} \mathrm{O}_{8}$ reserves in the Sierra Madre (Table 4) are unexpectedly rather large. However, an examination of the underlying data reveals the probable reason. There were only 4 of 31 transects or drill holes which encountered exceedances of $100 \mathrm{ppm}$ unleached $\mathrm{U}_{3} \mathrm{O}_{8}$. Allurly these four, three encountered relatively thin and low grade uranium concentrations, while one was substantially thicker and richer. Thus, the variance of accumulation (thickness $X$ value) was quite substantial and this large variance produced a corresponding large probable error. Because of the small number of encounters ( $i . e$. , only four), the estimate of probable error in this case should be regarded as somewhat unreliable ahd used only as a gencral indication of magnitude of error.

Since the data was available and may be of interest at some future date, resource estimates were also made for the tons of thorium oxide $\left(\mathrm{ThO}_{2}\right)$ exceeding $100 \mathrm{ppm}$. For this case, the whole leaching adjustment 


\begin{tabular}{|c|c|c|c|c|c|c|}
\hline $\begin{array}{l}\text { Depth } \\
\text { Interval }\end{array}$ & $\begin{array}{c}\text { Area per depth } \\
\text { interval of } \\
\text { mineable syrface } \\
\left(\mathrm{ft} .^{2}\right)\end{array}$ & $\begin{array}{l}\text { Leaching } \\
\text { correction } \\
\text { for } 1 \mathrm{n} \mathrm{U}_{3} \mathrm{O}_{8}\end{array}$ & $\begin{array}{c}\text { Tonnage } \\
\text { correction } \\
\text { (adjusted to leached } \\
\text { resource) }\end{array}$ & $\begin{array}{l}\text { Unleached } \\
\text { tons }>100 \mathrm{ppm} \\
\text { Jer depth } \\
\text { interval } \\
\end{array}$ & $\begin{array}{l}\text { Resource } \\
\text { tons }>100 \mathrm{ppm} \\
\text { after correction } \\
\text { for leaching } \\
\end{array}$ & $\begin{array}{c}\% \\
\text { Probable } \\
\text { error } \\
\end{array}$ \\
\hline $0-100$ & $3,343,000$ & 0.7063 & 0.2158 & 8.9 & 1.9 & 52.7 \\
\hline $100-200$ & $3,360,000$ & 0.0891 & 0.8457 & 9.0 & 7.6 & 52.7 \\
\hline $200-300$ & $3,360,000$ & 0 & 1.000 & 9.0 & 9.0 & 52.7 \\
\hline $300-400$ & $3,360,000$ & 0 & 1.000 & 9.0 & 9.0 & 52.7 \\
\hline $400-500$ & $3,029,000$ & 0 & 1.000 & 8.1 & 8.1 & 53.5 \\
\hline $500-1000$ & $16,236,000$ & 0 & 1.000 & 43.4 & 43.4 & 52.7 \\
\hline $1000-1500$ & $16,965,000$ & 0 & 1.000 & 45.4 & 45.4 & 52.7 \\
\hline $1500-2000$ & $16,965,000$ & 0 & 1.000 & 45.4 & 45.4 & 52.7 \\
\hline $2000-3000$ & $53,931,000$ & 0 & 1.000 & 90.8 & 90.8 & 52.7 \\
\hline $3000-4000$ & $33,931,000$ & 0 & 1.000 & 90.7 & 90.7 & 52.7 \\
\hline \multirow[t]{2}{*}{$4000-5000$} & $33,931,000$ & 0 & 1.000 & 90.7 & 90.7 & 52.7 \\
\hline & & & & Total & 442.0 tons & $52.7 \%$ \\
\hline
\end{tabular}

Tat le 4. Summary of Uranium Resource Calculations for Sierra Madre Init \#3.

*These probable errors are unexpectedly rather large. However, an examination of the underlying data reveals the probable reason. There were only 4 of 31 transects or drill holes which encountered exceedance of 100 ppm unleached $\mathrm{U}_{3} \mathrm{O}_{8}$. Among these four, three encountered relatively thin and low grade uranium concentrations, while one was substantially thicker and richer. Thus, the variance of accumulation (thickness $x$ value) was quite substantial and this large variance produced a corresponding large probable error. Because of the small number of encounters (i.e., only four), the estimate of probable error in this case should be regarded as somewhat unreliable and used only as a general indication of magnitude of error. 


\begin{tabular}{|c|c|c|c|c|c|c|}
\hline $\begin{array}{l}\text { Depth } \\
\text { Interval }\end{array}$ & $\begin{array}{c}\text { Area per depth } \\
\text { interval of } \\
\text { mineable surface } \\
(f t .2) \\
\end{array}$ & $\begin{array}{l}\text { Leaching } \\
\text { correction } \\
\text { for } \mathrm{InU}_{3} \mathrm{O}_{8}\end{array}$ & $\begin{array}{c}\text { Tonnage } \\
\text { correction } \\
\text { 'adjusted to leached } \\
\text { resource) } \\
\end{array}$ & $\begin{array}{l}\text { Unleacied } \\
\text { tons>10j ppm } \\
\text { per defth } \\
\text { interyal } \\
\end{array}$ & $\begin{array}{c}\text { Resource } \\
\text { tons }>100 \mathrm{ppm} \\
\text { after correction } \\
\text { for leaching } \\
\end{array}$ & $\begin{array}{c}\% \\
\text { Probable } \\
\text { error }\end{array}$ \\
\hline $0-100$ & $903,5 \cdot 00$ & 1.5484 & 0.0673 & 120.0 & 8.1 & 17.3 \\
\hline $100-200$ & 831,700 & 0.1604 & 0.9302 & 110.5 & 102.8 & 17.3 \\
\hline $200-300$ & 795,600 & 0 & 1.000 & $105 . ?$ & 105.7 & 17.3 \\
\hline $300-400$ & 704,100 & 0 & 1.000 & 93.5 & 93.5 & 17.4 \\
\hline $400-500$ & 633,100 & 0 & 1.000 & $88 . i$ & 88.1 & 17.6 \\
\hline $500-1000$ & $2,24 \vdots, 700$ & 0 & 1.000 & 298.1 & 298.1 & 16.7 \\
\hline $1000-1500$ & $58 c, 200$ & 0 & 1.000 & $78 . \vdots$ & 78.3 & 17.7 \\
\hline & & & & Total & 774.6 tons & $17.3 \%$ \\
\hline
\end{tabular}

Table 5. Summary of Uraniur Resource Calculation for Medicine Bow Unit \#1. 


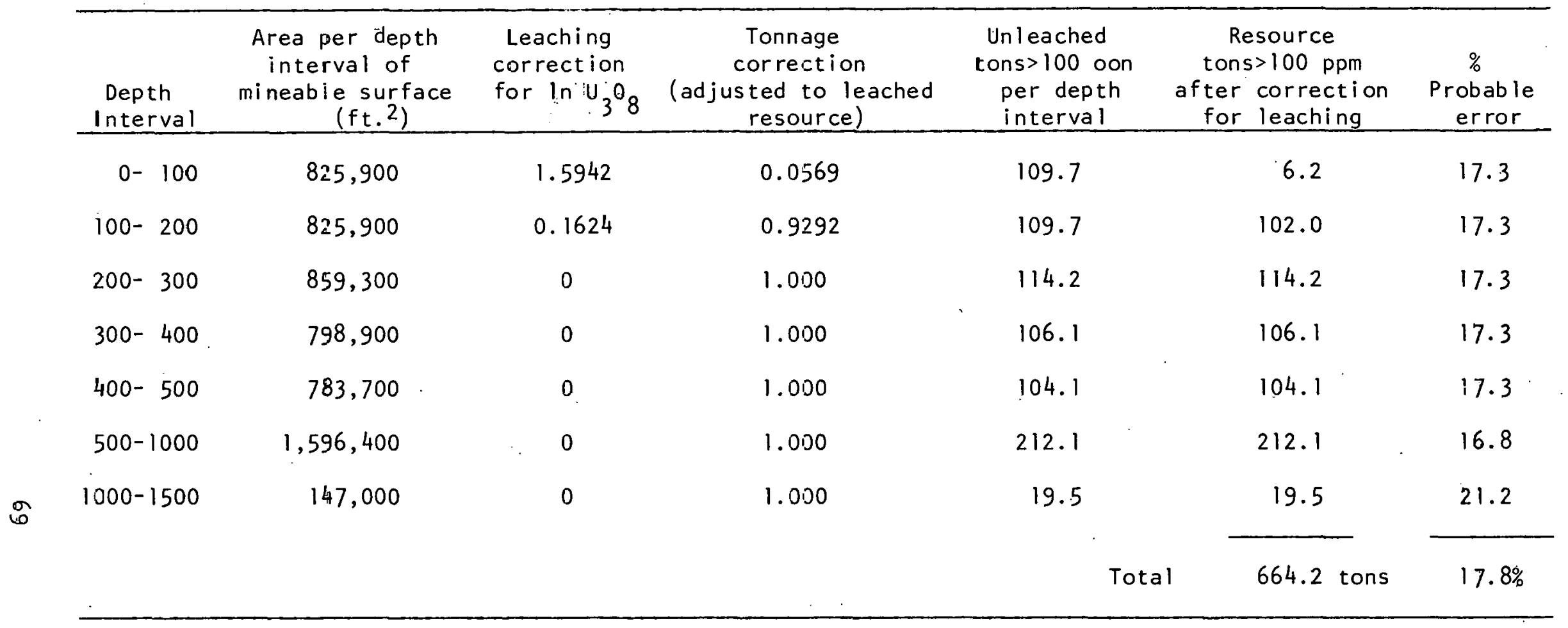

Table 6. Summary of Uranium Resource Calculations for Medicine Bow Unit \#5a. 


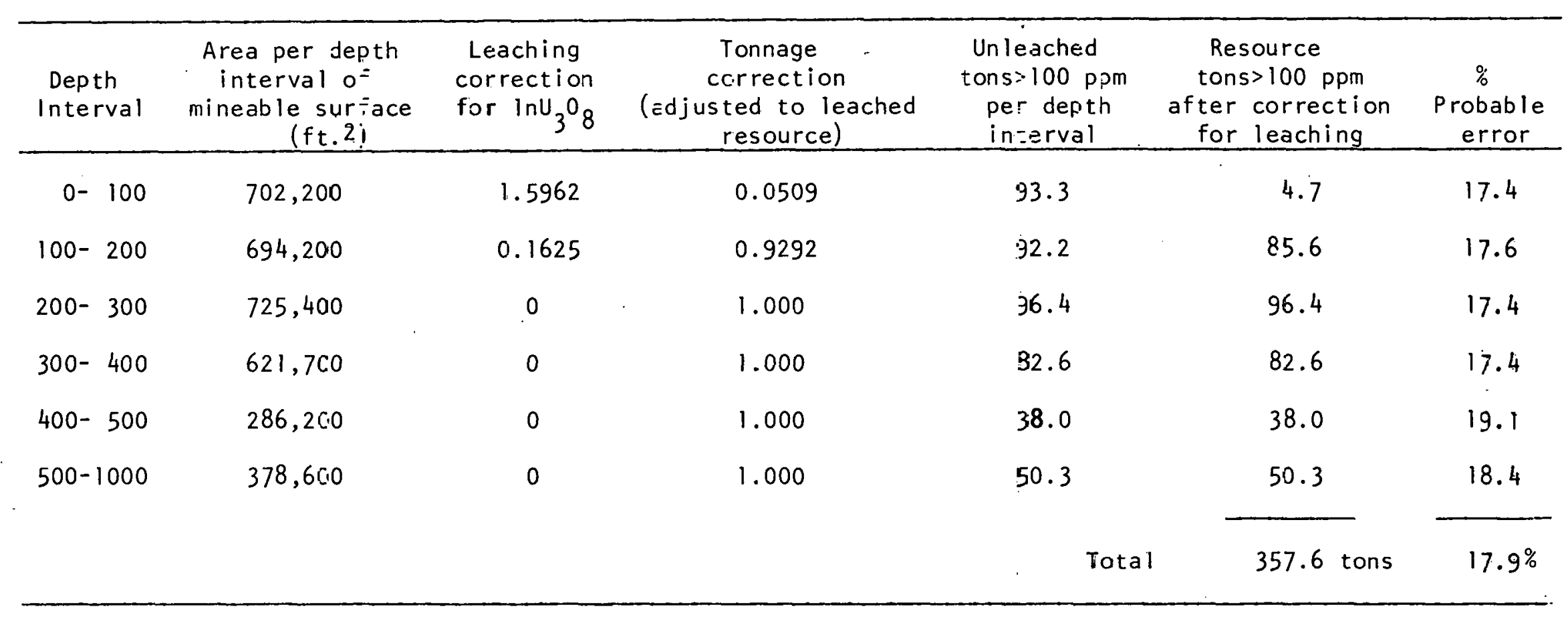

Table 7. Summary of Uranium Resource Calculations for Medicine Bow Unit \#5b. 


\begin{tabular}{|c|c|c|c|c|c|c|}
\hline $\begin{array}{l}\text { Depth } \\
\text { Interval }\end{array}$ & $\begin{array}{c}\text { Area per depth } \\
\text { interval of } \\
\text { mineable surface } \\
\left(\mathrm{ft} .{ }^{2}\right) \\
\end{array}$ & $\begin{array}{l}\text { Leaching } \\
\text { correction } \\
\text { for } \operatorname{lnU}_{3} 0_{8}\end{array}$ & $\begin{array}{c}\text { Tonnage } \\
\text { correction } \\
\text { (adjusted to leached } \\
\text { resource) } \\
\end{array}$ & $\begin{array}{l}\text { Unleached } \\
\text { rons }>100 \mathrm{ppm} \\
\text { per depth } \\
\text { interval } \\
\end{array}$ & $\begin{array}{c}\text { Resource } \\
\text { tons }>100 \text { ppm } \\
\text { after correction } \\
\text { for leaching } \\
\end{array}$ & $\begin{array}{c}\% \\
\text { Probable } \\
\text { error } \\
\end{array}$ \\
\hline $0-100$ & 675,600 & 1.5498 & 0.0670 & 89.7 & 6.1 & 17.6 \\
\hline $100-200$ & 675,700 & 0.1605 & 0.9302 & 89.8 & 83.5 & 17.6 \\
\hline $200-300$ & 675,700 & 0 & 1.000 & 89.8 & 89.8 & 17.6 \\
\hline $300-400$ & 671,200 & 0 & 1.000 & 89.2 & 89.2 & 17.6 \\
\hline $400-500$ & 669,000 & 0 & 1.000 & 88.9 & 88.9 & 17.6 \\
\hline $500-1000$ & $3,325,800$ & 0 & 1.000 & 441.8 & 441.8 & 16.6 \\
\hline $1000-1500$ & $3,163,300$ & 0 & 1.000 & 420.2 & 420.2 & 16.6 \\
\hline \multirow[t]{2}{*}{$1500-2000$} & $2,992,400$ & 0 & 1.000 & 397.5 & 397.5 & 16.7 \\
\hline & & & & Total & 1617.0 tons & $17.2 \%$ \\
\hline
\end{tabular}

Table 8. Summary of Uranium Resource Calculations for Threemile Creek area, Medicine Bow Mountains. 
and tonnage correction was unnecessary, since thorium is relatively unaffected by leaching. These somewhat smaller tables for the tonnage of $\mathrm{ThO}_{2}$ exceeding $100 \mathrm{ppm}$ are given in Tables 9 to 13.

Since there may be some interest in what was the maximum value of $\mathrm{U}_{3} \mathrm{O}_{8}$ unleached equivalent values which were encountered in the drill holes where the values did not rise above $100 \mathrm{ppm}$, the maximum values encountered in these holes are summarized in Tables 14 and 15 . Finally the overall resource estimates for the Deep Gulch Formation in the northwestern Sierra Madre and for the Onemile Creek area of the northeastern Medicine Bow Mountains are tabulated in Table 16 and 17 for $\mathrm{U}_{3} \mathrm{O}_{8}$ and $\mathrm{ThO}_{2}$ respectively.

Judgements Concerning Geological Uncertainty

Any evaluation of uranium resources is strongly dependent on a geologic understanding of the geometry of the mineralized bodies. The geostatistical resource estimate presented in this report reflects our current understanding of the structure and stratigraphy of the Onemile Creek area and the Carrico Ranch area, based on surface mapping at a scale of 1:1200 and on subsurface, drill-core data. In both areas, the mineralized units have been folded at least twice, faulted, and intruded by mafic magmas. As a consequence of this complex deformational history (and in spite of detailed mapping and reconnaissance drilling) the re are still geologic uncertainties in extrapolating outcrop information into areas of poor outcrop and into the subsurface. For this report, we have evaluated what we consider to be the most reasonable geometry of the 


\begin{tabular}{|c|c|c|c|}
\hline $\begin{array}{l}\text { Depth } \\
\text { Interval }\end{array}$ & $\begin{array}{c}\text { Area per Depth } \\
\text { Interval ot } \\
\text { Mineable Surface }\end{array}$ & $\begin{array}{c}\text { Resource } \\
\text { Tons }>100 \mathrm{ppm}\end{array}$ & $\begin{array}{c}\% \\
\text { Probable } \\
\text { Error }\end{array}$ \\
\hline $0-100$ & $3,343,000$ & $126: 6$ & 16.0 \\
\hline $100-200$ & $3,360,000$ & .126 .7 & 16.0 \\
\hline $200-300$ & $3,360,000$ & .126 .7 & 16.0 \\
\hline $300-400$ & $3,360,000$ & 126.9 & 16.0 \\
\hline $400-500$ & $3,029,000$ & 114.2 & 16.0 \\
\hline $500-1000$ & $16,236,000$ & 612.5 & 15.8 \\
\hline $1000-1500$ & $16,965,000$ & 640.0 & 15.8 \\
\hline $1500-2000$ & $16,965,000$ & 639.7 & 15.8 \\
\hline $2000-3000$ & $33,931,000$ & 1230.0 & 15.8 \\
\hline $3000-4000$ & $33,931,000$ & 1280.0 & 15.8 \\
\hline \multirow[t]{2}{*}{$4000-5000$} & $33,931,000$ & 1280.0 & 15.8 \\
\hline & Total & 6353.3 Tons & $15.9 \%$ \\
\hline
\end{tabular}

Table 9. Summary of Thorium Resource Calculatlons for Sierra Madrc Unit \#3. 


\begin{tabular}{|c|c|c|c|c|}
\hline $\begin{array}{l}\text { Depth } \\
\text { Interval } \\
\end{array}$ & $\begin{array}{c}\text { Area per Depth } \\
\text { Interval of } \\
\text { Mineable Surface }\left(\mathrm{ft} .^{2}\right)\end{array}$ & & $\begin{array}{c}\text { Resource } \\
\text { Tons }>100 \mathrm{ppm}\end{array}$ & $\begin{array}{l}\% \\
\text { Probable } \\
\text { Error }\end{array}$ \\
\hline $0-100$ & $90 \cdot 3,500$ & & 62.6 & .15 .2 \\
\hline $100-200$ & 831,700 & & 57.6 & $15: 4$ \\
\hline $200-300$ & 795,600 & & 55.1 & 15.4 \\
\hline $300-400$ & 704,100 & & 48.8 & 15.5 \\
\hline $400-500$ & 633,100 & & 45.9 & 15.5 \\
\hline $500-1000$ & $2,243,700^{\circ}$ & & 155.4 & 14.8 \\
\hline \multirow[t]{2}{*}{$1000-1500$} & 589,200 & & 40.8 & 15.6 \\
\hline & & Total & 466.2 tons & $15.3 \%$ \\
\hline
\end{tabular}

Table 10. Summary of Thorium Resource Calculations for Medicine Bow Unit \#1. 


\begin{tabular}{|c|c|c|c|}
\hline $\begin{array}{c}\text { Depth } \\
\text { Interval } \\
\end{array}$ & $\begin{array}{l}\text { Area per Depth } \\
\text { Interval of } \\
\text { Mineable Surface }\left(\mathrm{ft}^{2}{ }^{2}\right)\end{array}$ & $\begin{array}{c}\text { Resource } \\
\text { Tons }>100 \mathrm{ppm} \\
\end{array}$ & $\begin{array}{l}\% \\
\text { Probable } \\
\text { Error }\end{array}$ \\
\hline $0-100$ & 825,900 & 57.2 & 15.4 \\
\hline $100-200$ & 825,900 & 57.2 & 15.4 \\
\hline $200-300$ & 859,300 & 59.5 & 15.2 \\
\hline $300-400$ & 798,900 & 55.3 & 15.4 \\
\hline $400-500$ & 783,700 & 54.3 & 15.4 \\
\hline $500-1000$ & $1,596,400$ & 110.6 & 1.4 .9 \\
\hline \multirow[t]{3}{*}{$1000-1500$} & 147,000 & 10.2 & 18.7 \\
\hline & Total & 404.3 Tons & $15.8 \%$ \\
\hline & & & . \\
\hline
\end{tabular}

Table 11. Summary of Thorium Resource Calculations for Medicine Bow Unit \#5a. 


\begin{tabular}{|c|c|c|c|}
\hline $\begin{array}{c}\text { Depth } \\
\text { Interval } \\
\end{array}$ & $\begin{array}{l}\text { Area per Depth } \\
\text { Interval of } \\
\text { Mineable Surface }\left(\mathrm{ft}^{2}{ }^{2}\right) \\
\end{array}$ & $\begin{array}{c}\text { Resource } \\
\text { Tons }>100 \mathrm{ppm}\end{array}$ & $\begin{array}{l}\% \\
\text { Probable } \\
\text { Error }\end{array}$ \\
\hline $0-100$ & 702,200 & 48.6 & 15.5 \\
\hline $100-200$ & 694,200 & 48.1 & 15.5 \\
\hline $200=300$ & 725,400 & 50.2 & 15.5 \\
\hline $300-400$ & 621,700 & 43.0 & 15.6 \\
\hline $400-500$ & $2.86,200$ & 19.8 & 16.8 \\
\hline \multirow[t]{2}{*}{$500-1000$} & 378,600 & 26.2 & 16.3 \\
\hline & Total & 235.9 Tons & $15.9 \%$ \\
\hline
\end{tabular}

Table 12. Summary of Thorium Resource Calculations for Medicine Bow Unit \#5b. 


\begin{tabular}{cccc}
\hline $\begin{array}{c}\text { Depth } \\
\text { Interval }\end{array}$ & $\begin{array}{c}\text { Area per depth } \\
\text { interval of } \\
\text { Mineable Surface }\left(\mathrm{ft}^{2}{ }^{2}\right)\end{array}$ & $\begin{array}{c}\text { Resource } \\
\text { tons }>100 \text { ppm }\end{array}$ & $\begin{array}{c}\% \\
\text { Probable } \\
\text { error }\end{array}$ \\
\hline $0-100$ & 675,600 & 46.8 & 15.5 \\
$100-200$ & 675,700 & 46.8 & 15.5 \\
$200-300$ & 675,700 & 46.8 & 15.5 \\
$300-400$ & 671,200 & 46.5 & 15.5 \\
$400-500$ & 669,000 & 46.3 & 15.5 \\
$500-1000$ & $3,325,800$ & 230.4 & 14.6 \\
$1000-1500$ & $3,163,300$ & 219.1 & 14.6 \\
$1500-2000$ & $2,992,400$ & 207.3 & 14.8 \\
\hline
\end{tabular}

Table 13. Summary of Thorium Resource Calculations for Threemile Creek area, Medicine Bow Mountains. 


\begin{tabular}{|c|c|c|c|c|c|}
\hline Drill Unit \# & \multicolumn{2}{|c|}{$\begin{array}{l}\text { Unit I } \\
\text { Unt Th }\end{array}$} & \multicolumn{2}{|c|}{$\begin{array}{l}\text { Unit } 2 \\
\text { Unt Th }\end{array}$} & $\begin{array}{l}\text { Unit } 4 \\
\text { Unt Th }\end{array}$ \\
\hline$S M-1$ & 3.7 & 20 & 29 & $130^{(250)}$ & 18 \\
\hline$S M-1 A$ & 64.0 & 400 & 35.0 & $26^{(230)}$ & $14 \quad 140$ \\
\hline$S M-2$ & no enco & unter & & $110^{(120)}$ & $12.217^{(64)}$ \\
\hline$S M-3$ & 21 & 20 & 36 & $100^{(220)}$ & no. encounter \\
\hline$J P-1$ & 4.6 & 9 & 27 & 97 & $26: 220$ \\
\hline$J P-2$ & 29 & 220 & 26 & 150 & $20^{(34)}$ \\
\hline$J P-3$ & 4.2 & 15 & no $e$ & ncounter & no encounter \\
\hline$J P-4$ & 42 & 170 & no $\epsilon$ & ncounter & 14 \\
\hline
\end{tabular}

Table 14. Highest uranium and thorium values from units $1,2,4$ from drill cores in the Sierra Madre.

*Value in parentheses indicates highest spot sample. 
Lithologic Units

\begin{tabular}{|c|c|c|c|c|c|}
\hline $\begin{array}{l}\text { Drill Hole } \\
\text { or: transect }\end{array}$ & $\mathrm{U}_{3} \mathrm{O}_{8}^{1} \mathrm{ThO}_{2}$ & $\mathrm{U}_{3} \mathrm{O}_{8}^{2} \mathrm{ThO}_{2}$ & $\mathrm{U}_{3} \mathrm{O}_{8}^{3} \mathrm{ThO}_{2}$ & $\mathrm{U}_{3} \mathrm{O}^{4} \mathrm{ThO}_{2}$ & $\mathrm{U}_{3} \mathrm{O}_{8}^{5} \mathrm{ThO}_{2}$ \\
\hline EMB-1 & $c(1) c(1)$ & $c(1) c(1)$ & $c(1) c(1)$ & 24.821 .6 & NE \\
\hline EMB-2 & NE & NE & NE & $E-N D$ & $E-N D$ \\
\hline EMB-3 & NE & NE & NE & NE & NE \\
\hline EMB- 4 & NE & NE & NE & NE & NE \\
\hline EMB-6 & NE & NE & NE & $E-N D$ & $c(2,3) \quad c(2,3)$ \\
\hline EMB-7 & NE & NE & $N E$ & $c(2) \quad c(2)$ & $c(2,3) \quad c(2,3)$ \\
\hline$E M B-8$ & $N E$ & $N E$ & NE & $E-N D$ & $c(3) c(3)$ \\
\hline EMB-9 & NE & NE & NE & $N E$ & $c(3) c(3)$ \\
\hline$E M B-10$ & NE & NE & NE & $N E$ & $c(3) 84.2$ \\
\hline$E M B-11$ & $N E *$ & $N E *$ & $N E *$ & $N E *$ & $N E *$ \\
\hline$M B-16$ & $c(1) c(1)$ & $c(1) e(1)$ & 34.829 .6 & NE & NE \\
\hline$T 1 A$ & $c(1) c(1)$ & $c(1) c(1)$ & NE & NE & NE \\
\hline $\mathrm{T} 1 \mathrm{~B}$ & $c(1) c(1)$ & $c(1) c(1)$ & NE & NE & NE \\
\hline TrC & $c(1) c(1)$ & $c(1) c(1)$ & NE & NE & NE \\
\hline $\mathrm{T} 2$ & $c(1) 96.7$ & $c(1) c(1)$ & $20.8: 92.2$ & 14.051 .2 & NE \\
\hline T3 & NE & NE & NE & NE & $c(3) \cdot c(3)$ \\
\hline$T 4$ & NE & NE & NE & $c(2) \quad c(2)$ & NE \\
\hline T5 & NE & NE & NE & $c(2) \quad c(2)$ & $c(2,3) \quad c(2,3)$ \\
\hline T6 & NE & NE & NE & $87.6 \quad 61.8$ & $75.8 \mathrm{c}(3)$ \\
\hline $\mathrm{TT}$ & NE & NE & NE & NE & $c(3) c(3)$ \\
\hline T8 & NE & NE & NE & $c(2) c(2)$ & $c(2,3) \quad c(2,3)$ \\
\hline
\end{tabular}

NE - Not encountered by drill hole or transect

NE*- Units encountered do not correlate with these lithologic units

$c(1)$ - Used in resource calculation; number indicates which resource geometry includes this unit:

1- Unit 1, Onemile Creek area

2- Unit 5a, Onemile Creek area

3- Unit 5b, Onemile Creek area

$\mathrm{U}_{3} \mathrm{O}_{8}$ and $\mathrm{ThO}_{2}$ are reported in ppm and maximum $\mathrm{ThO}_{2}$ may not be from same sample as maximum $U_{3}{ }^{0}$.

Table 15. Maximum uranium and thorium values $<100 \mathrm{ppm}$ encountered in Magnolia Formation lithologic units, Medicine Bow Mountains. 


\begin{tabular}{|c|c|c|c|c|c|c|}
\hline \multirow{2}{*}{$\frac{}{\text { Depth }(\text { lnterval }}$} & \multicolumn{3}{|c|}{$\begin{array}{c}\text { Deep Gulch Formation } \\
\text { Northwestern Sierra } \\
\text { Madre Mountains }\end{array}$} & \multicolumn{3}{|c|}{$\begin{array}{c}\text { Magnolia Formation } \\
\text { Northeastern } \\
\text { Medicine Bow Mountains }\end{array}$} \\
\hline & \multicolumn{2}{|c|}{$\begin{array}{l}\text { Tòns } \mathrm{U}_{3} \mathrm{O}_{8} \\
>100 \text { P.pm }\end{array}$} & $\begin{array}{l}\text { Probable } \\
\text { Error } \%\end{array}$ & \multicolumn{2}{|c|}{$\begin{array}{l}\text { Tons } \mathrm{U}_{3} \mathrm{O}_{8} \\
=100 \mathrm{Ppm}\end{array}$} & \multirow{2}{*}{$\begin{array}{c}\begin{array}{c}\text { Próbäb le } \\
\text { Error \% }\end{array} \\
16.6\end{array}$} \\
\hline $0-.100$ & 1.9 & & $52.7 *$ & 25.1 & & \\
\hline $100-200$ & 7.6 & & 52.7 & 378.9 & & 16.7 \\
\hline $200-300$ & 9.0 & & 52.7 & 406.0 & & 16.7 \\
\hline $300-400$ & 9.0 & & 52.7 & 371.4 & & 16.7 \\
\hline $400-500$ & 8.1 & & 53.5 & 319.1 & & 16.7 \\
\hline $500-1000$ & 43.4 & & 52.7 & 1002.2 & & 16.5 \\
\hline $1000-1500$ & 45.4 & & 52.7 & 518.0 & & 16.6 \\
\hline $1500-2000$ & 45.4 & & 52.7 & 397.5 & & 16.7 \\
\hline $2000-3000$ & 90.8 & & 52.7 & & & \\
\hline $3000-4000$ & 90.7 & & 52.7 & & v & \\
\hline $4000-5000$ & 90.7 & & 52.7 & & & \\
\hline Total & 442.0 & tons & $52.7 \%$ & $3418.2 t$ & tons & $16.7 \%$ \\
\hline \multicolumn{7}{|l|}{$\begin{array}{l}\text { Average grade for } \\
\mathrm{U}_{3} \mathrm{O}_{8} \text { exceeding }\end{array}$} \\
\hline $100 \mathrm{ppm}$ & \multicolumn{3}{|c|}{$130.2 \mathrm{ppm}$} & \multicolumn{3}{|c|}{$305.7 \mathrm{ppm}$} \\
\hline $\begin{array}{l}\text { Average total } \\
\text { thlckness of beds } \\
\text { with } \mathrm{U}_{3} \mathrm{O}_{8} \text { exceeding } \\
100 \mathrm{ppm}\end{array}$ & & & 5 feet & & & feet \\
\hline Thickness per bed & & & 6 feet & & & 95 feet \\
\hline Map area & & $12 \cdot 5 q$ & q. miles & & & 5 sq. miles \\
\hline
\end{tabular}

Table 16. Resource summary for tons $\mathrm{U}_{3} \mathrm{O}_{8}$ with grade exceeding $100 \mathrm{ppm}$ for the listed areas, together with other basic statistics.

*See footnote on Table 4. 


\begin{tabular}{|c|c|c|c|c|c|}
\hline \multirow[b]{2}{*}{$\begin{array}{c}\text { Depth Interval } \\
\text { (feet) }\end{array}$} & \multicolumn{2}{|c|}{$\begin{array}{l}\text { Deep Gulch Formation } \\
\text { Northwestern Sierra } \\
\text { Madre Mountains }\end{array}$} & \multicolumn{3}{|c|}{$\begin{array}{c}\text { Magnolia Formation } \\
\text { Northeastern } \\
\text { Medicine Bow Mountains }\end{array}$} \\
\hline & $\begin{array}{l}\text { Tons Tho } \\
>100 \mathrm{ppm} \\
\end{array}$ & $\begin{array}{l}\text { Probable } \\
\text { Error \% }\end{array}$ & $\begin{array}{l}\text { Tons Th0 } \\
>100 \mathrm{ppm}\end{array}$ & & $\begin{array}{l}\text { Probable } \\
\text { Error \% }\end{array}$ \\
\hline $0-100$ & 126.6 & 16.0 & 215.2 & & 14.8 \\
\hline $100-200$ & 126.7 & 16.0 & 209.6 & & 14.8 \\
\hline $200-300$ & 126.7 & 16.0 & 211.7 & & 14.8 \\
\hline $300-400$ & 126.9 & 16.0 & 193.6 & & 14.8 \\
\hline $400-500$ & 114.2 & 16.0 & 166.4 & & 14.8 \\
\hline $500-1000$ & 612.5 & 15.8 & 522.5 & & 14.5 \\
\hline $1000-1500$ & 640.0 & 1.5 .8 & 270.1 & & 14.6 \\
\hline $1500-2000$ & 639.7 & 15.8 & 207.3 & & 14.8 \\
\hline $2000-3000$ & 1280.0 & 15.8 & & & \\
\hline $3000-4000$ & 1280.0 & 15.8 & & & \\
\hline $4000-5000$ & 1280.0 & 15.8 & & & \\
\hline Total & 6353.3 tons & $15.9 \%$ & $1996.4 \mathrm{t}$ & tons & $14.7 \%$ \\
\hline $\begin{array}{l}\text { Average grade } \\
\text { for Tho } 2 \\
\text { exceeding } 100 \mathrm{ppm}\end{array}$ & 265. & ppm & & 284. & $5 \mathrm{ppm}$ \\
\hline $\begin{array}{l}\text { Average total } \\
\text { thickness of beds } \\
\text { with ThO }{ }_{2} \text { exceeding } \\
100 \mathrm{ppm}^{2}\end{array}$ & & feet & & & 5 feet \\
\hline $\begin{array}{l}\text { Thickness per bed. } \\
\text { Map area }\end{array}$ & & $i^{2}$ & & & $\begin{array}{l}\text { 8. feet } \\
5 \mathrm{mi}^{2}\end{array}$ \\
\hline
\end{tabular}

Table 1\%. Resource summary for tons $\mathrm{ThO}_{2}$ with grade exceeding $100 \mathrm{ppm}$ for the listed areas, together with other basic statistics. 
mineralized units. However, in this section it is fruitful to examine other feasible geologic interpretations which could result in either larger uranium reserve estimates (terms "optimistic" interpretations) or smaller reserves estimates ("pessimistic" interpretations).

For the Medicine Bow areas, there are three major uncertainties in interpreting the subsurface extent of mineralized units in the Magnolia Formation: The first twe, the plunge of the major syncline and the shape and extent of the llafic intrusive bodies, involve outcropping Magnolla Formation of both the Onemile Creek and the Threemi le Creek areas. The third deals with the possibility of subcropping Magnolia Formation unconformably underlying the Cascade Quartzite east of Onemi le Creek.

The major structure in the Onemile Creek area is a faulted and intruded, tight to isoclinal overturned syncline. Figure 14 shows two possible plunges for this syncline. Figure 14a, an inclined syncline, is consistent with the macroscopic pattern of the Magnolia Formation which can be traced through the Threemile Creek area over a distance of 6 miles to the southwest, into an area of open, upright folds with subhorizontal fold axes. Figure 14b, a reclined syncline, is suggested by mesoscopic fold configurations in the Onemile area. We have used the inclined fold geometry of $14 a$ in our resource estimate because it explains regional relationships better and because we believe the mesoscopic fold structures are related to a superposed fold system which is well documented by stereonet plots of bedding foliations and lineations. Nevertheless; if the reclined fold plunge of $14 \mathrm{~b}$ were used, the resources estimate would change. Figure 15 and 16 show schematic east-west cross-sections of part of the Onemile syncline using both interpretations. With the reclined 

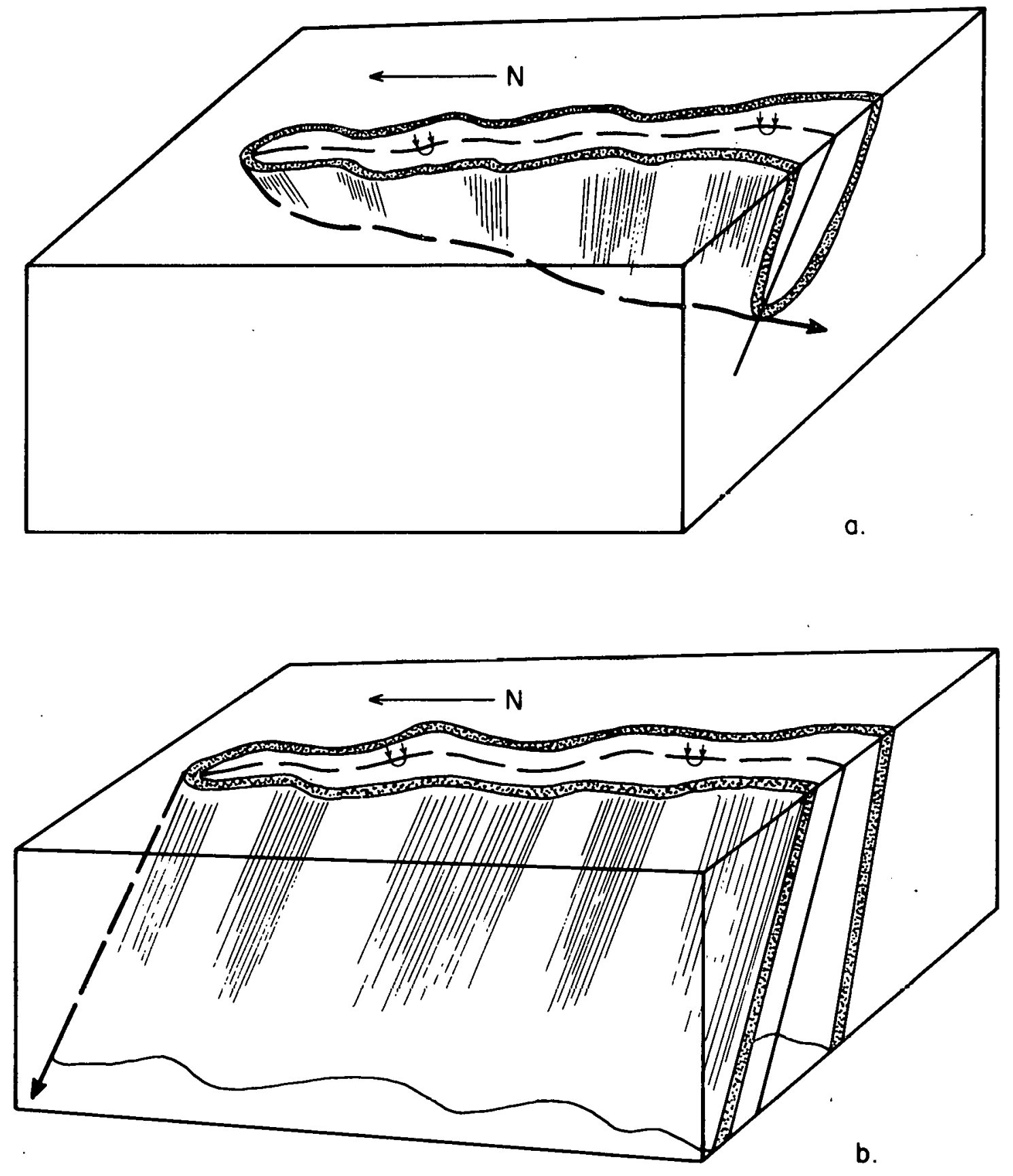

Figure 14. Schematic diagrams of possibe styles of folding in the Onemile Creek area: a) inclined, b) reclined. Heavy dashed line with arrow shows plunge of fold. 


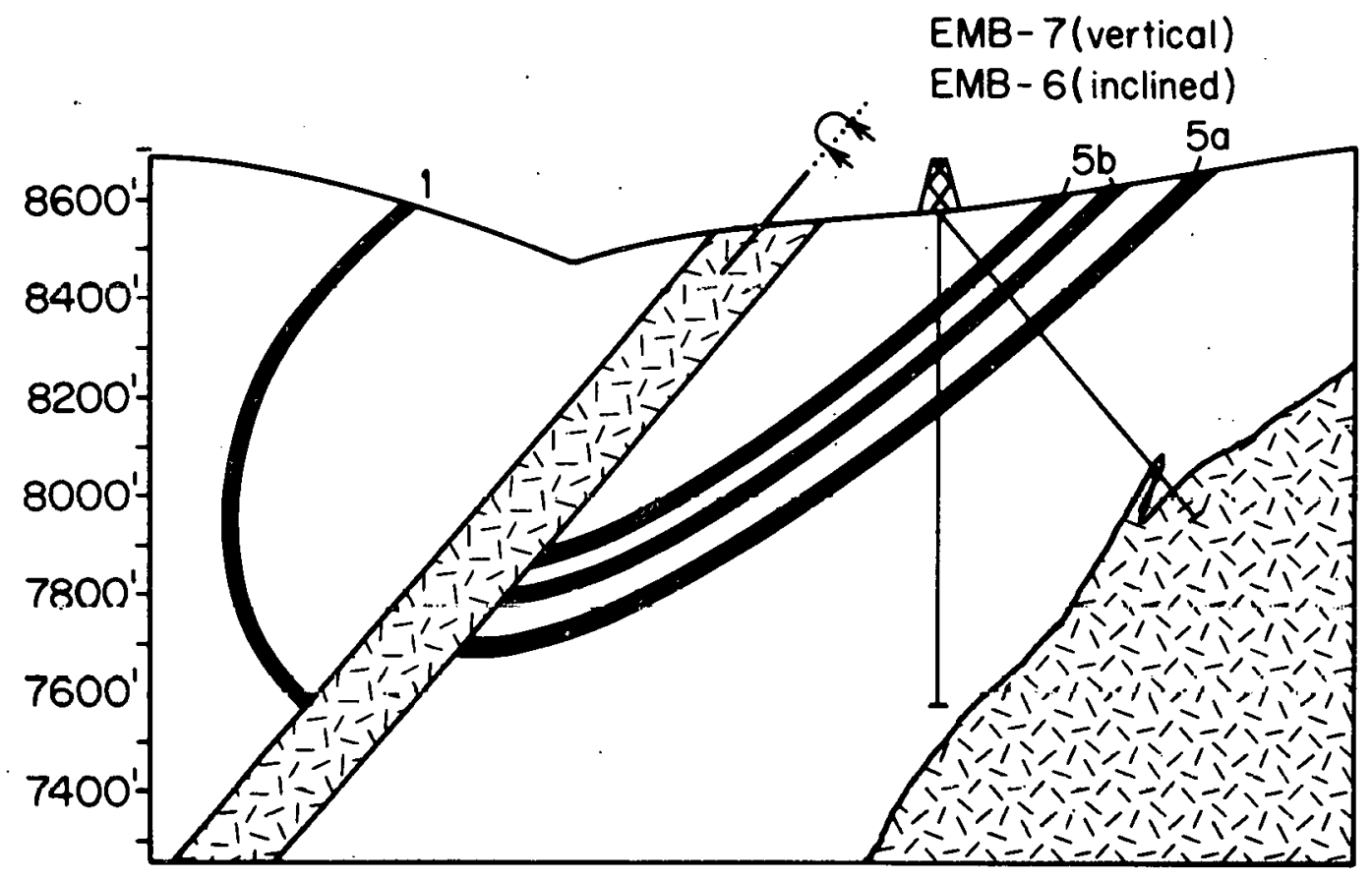

a. Inclined fold with mafic sill.

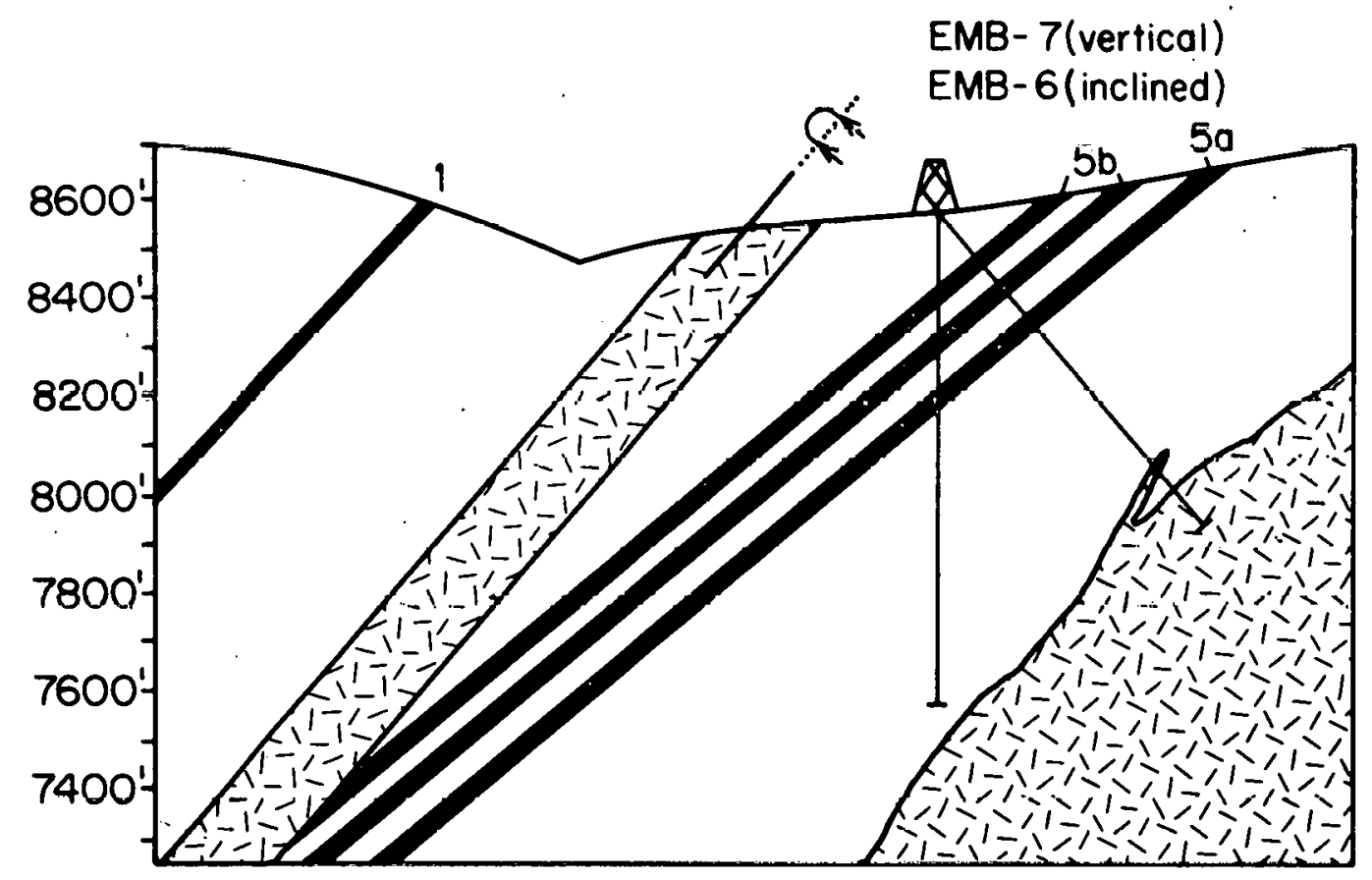

b. Reclined fold with mafic sill.

Figure 15. Possible fold geometries with mafic bodies modelled as sills. 


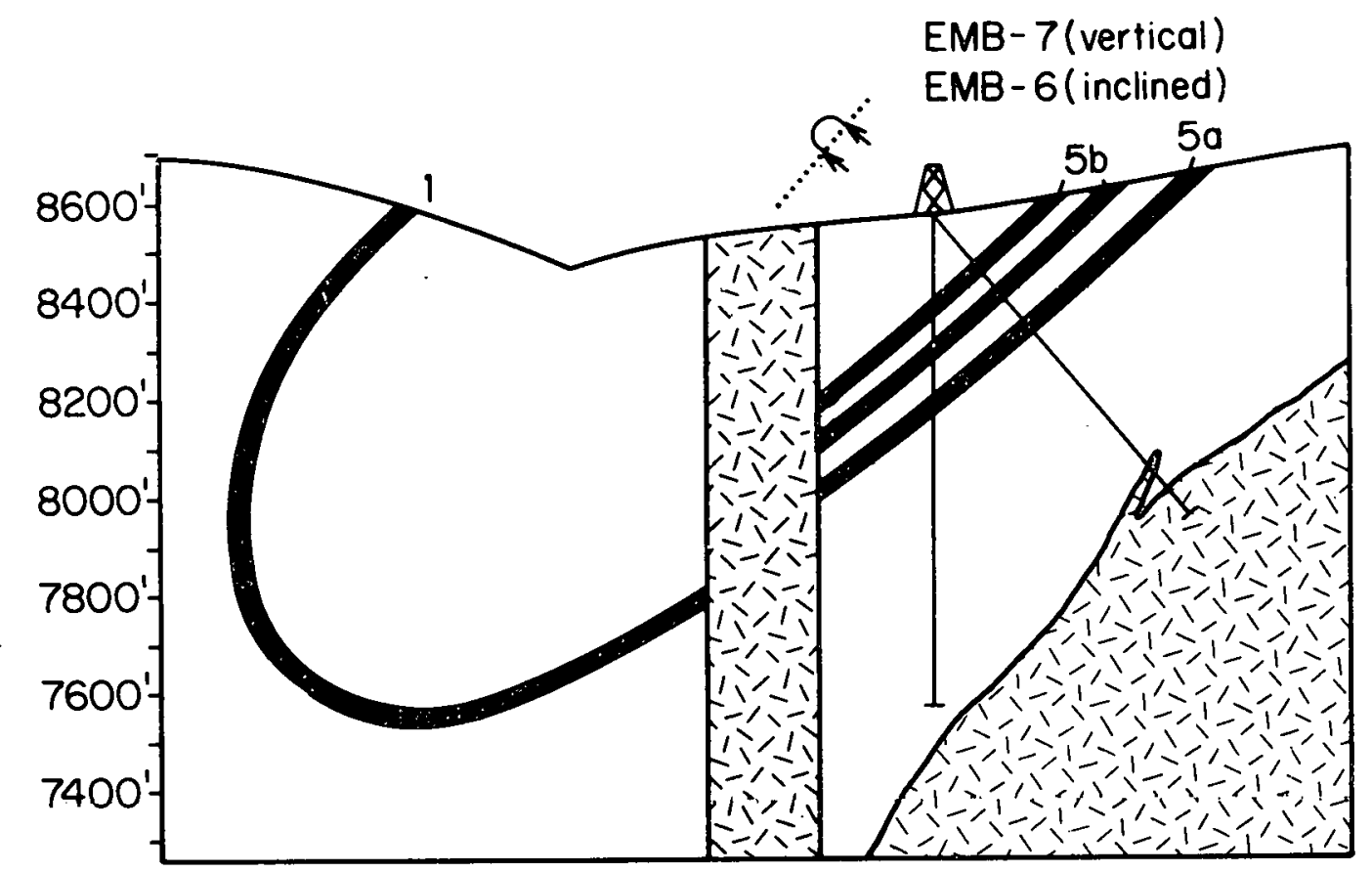

a. Inclined fold with vertical dike.

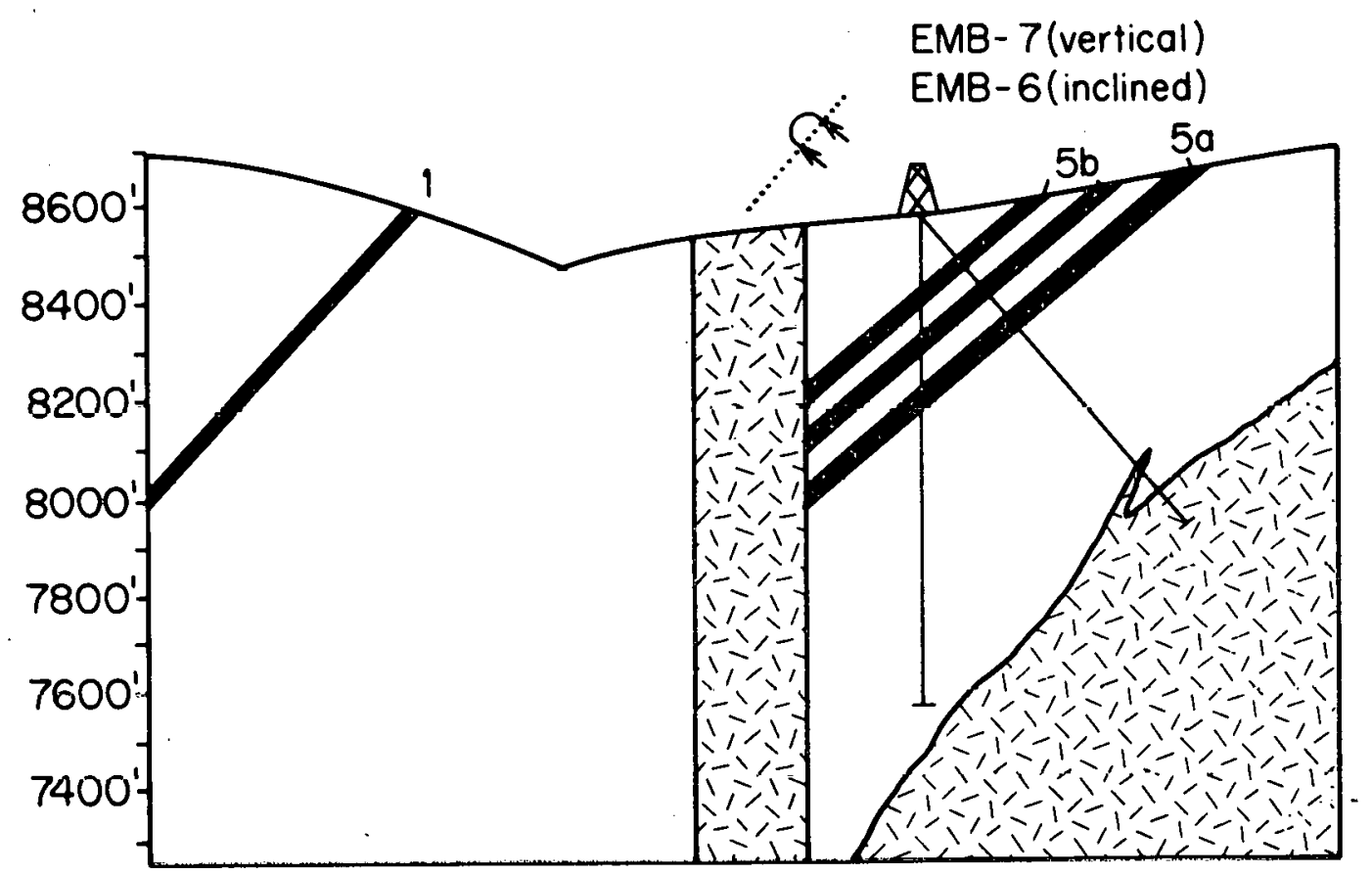

b. Reclined fold with vertical dike.

Figure 16. Possible fold geometries with mafic bodies modelled as vertical dikes. 
syncline 14b, mineralized zones would extend to greater depths (averaging 2000 feet instead of $1000 \mathrm{feet}$ ) and the reserve figure would be increased by a factor of about 2, if extended to the required depth of 5000 feet. Projection of the Threemi le Creek geometry as an inclined syncline to 5000 feet was considered unsupported by our subsurface information but this projection would also double the reserve figure.

The problem of the shape of mafic. intrusive bodies is al so illustrated in Figures 15 and 16 . We believe lhat the bodies are mainly sill-like and that they were intruded along bedding planes and faults which parallel the axial plane of the fold. However, the bodies could either thicken or thin with depth or remain fairly uniform in thickness. Figure 15, which represents our favored interpretation of sill-like shapes, gives a reasonably optimistic uranium resource estimate, Figure 16 , showing geologically unreasonable vertical mafic dikes, would give a pessimistic estimate. If the latter were used, the resource number could be decreased by a factor of .5 .

The third problem, of the possibility of subcropping Magnolia east of Onemile Creek, is difficult to evaluate and we have neglected such a possibility in our resource estimate. However, Figure 3 (map), shows the hinge of the major syncline to be offset left laterally inlu Llis area. so there may be mineralized Magnolia in the subcrop. If so, it is conceivable that the resource estimate should be increased by a factor of 1.5 or 2 . Table 17 summarizes what we consider to be llie extremes of optimistic versus pessimistic geologic interpretations in the Medicine Bow area and how they would affect the present resource number $(R)$ reported earlier. 
TABLE 18

Possible optimistic geometry

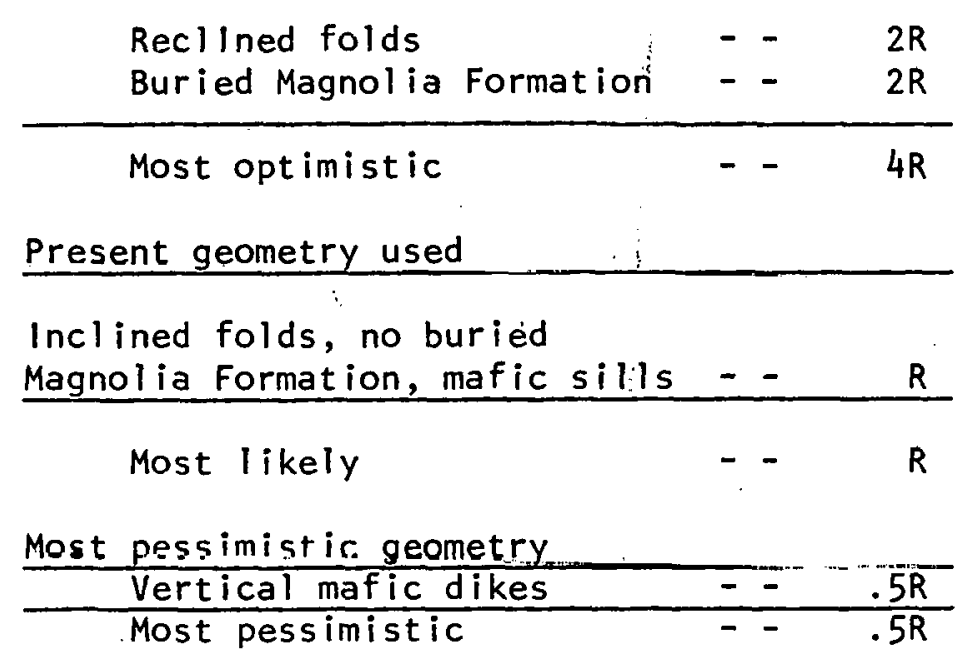

We believe our present interpretation is geologically most reasonable but other geologic interpretations could increase the estimate by a factor up to 4 times or decrease it by about one-half.

For the Sierra Madre area, geologic uncertainties in interpreting the structure of the Deep Gulch Formation of the Carrico Ranch area involve the subsurface projection of the unit. The unit maintains a fairly uniform overturned dip of about 50 degrees for a lateral distance of at least four miles and drill data indicate these dips remain uniform in the subsurface at least to depths of $500-1000$ feet. Therefore, we have projected it farther, to depths of 5000 feet, in our reserve est imate.

However, the overturned beds are part of a large overturned reclined syncline, plunging west, which has only been partly defined; we have not found the equivalent beds in the upright limb of the syncline on the surface and we believe there are large reverse faults parallel to the 
axial planes of the folds. As a consequence, it is possible that the mineralized unit is truncated at levels shallower than 5000 feet, (Figure 17B), decreasing the reserve estimate, or is repeated by folding, (Figure 1:7.A), increasing the estimate. Figure 17 shows these two possibilities plus the interpretation used in our resource estimate $(17 \mathrm{C})$. The pessimistic interpretation could decrease the estimate by a factor of . 2 ; the optimistic interpretation could increase the estimate by a factor of 2 or 3 . The present, optimistic and pessimistic estimations for the Sierra Madre are summarized in Table 19.

TABLE 19

\begin{tabular}{l|l|l} 
Optimistic & Present & Pessimistic \\
Repeated Folding-2 or $3 R$ & Cont inuous Dip-R & Reverse Faulting-.2R \\
\hline Most optimistic-2R to $3 R$ & Most likely-R & Most Pessimistic-.2R \\
\hline
\end{tabular}

A quantitative statistical version of this geological uncertainty, as based on a careful consideration of the factors previously outlined is shown in Table 20.

\section{Geologists Subjective Probability}

Actual Resource Sierra Madre Area Medicine Bow Area

$\begin{array}{lcc}R / 2 & .15 & .05 \\ R & .75 & .50 \\ 2 R & .05 & .25 \\ 3 R & .05 & \\ \begin{array}{l}\text { Expected Actual } \\ \text { Resource }\end{array} & 1.075 R \\ \text { Table 20. } & \begin{array}{l}\text { Estimated (subject ive) probabilities the } \\ \text { actual resource is less or more than that } \\ \text { derived from the geostatistical analysis. }\end{array}\end{array}$




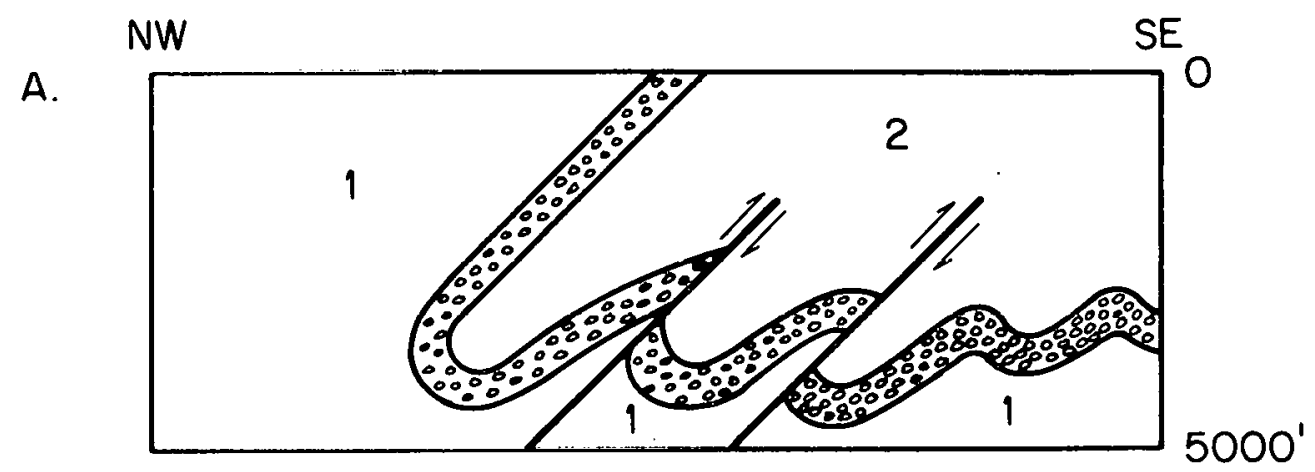

B.
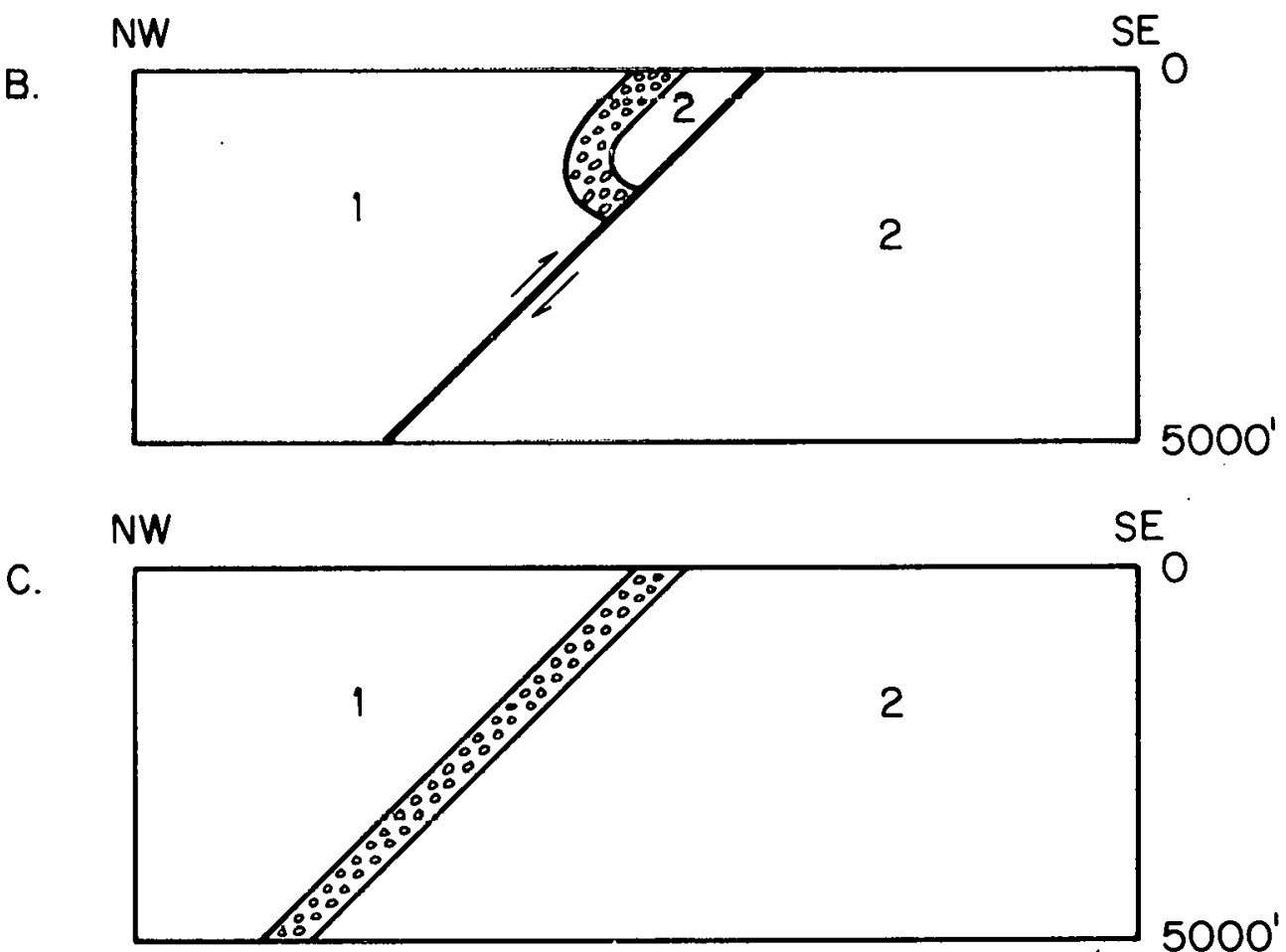

Figure 17. Optimistic (A), pessimistic (B) and favored (C) interpretations of the subsurface extent of the Deep Gulch Formation in the Northwest Sierro Madre. $1=$ basement gneiss; $\therefore 00$ = Deep Gulch Formation; $2=$ quartzites and metavolcanic rocks of the Phantom Lake metamorphic Suite. 
This may be interpreted in words as suggesting that geological judgment gives very little chance for much more resource being found in the Sierra Madre, but there may be as much as 62 percent more tonnage than estimated in the Medicine Bow Mountains. This all is, of course, very speculative but it does provide some measure of the geological uncertainties involved in the interpretations. 
$\therefore \quad$ SUMMARY AND CONCLUSIONS

1. The uranium endowment in Precambrian pebble conglomerate metasediments in the Sierra Madre and Medicine Bow Mountains of southeastern Wyoming was determined through an investigation which carefully coordinated geology with mining geostatistics.

2. The resource assessment consisted of four phases of activity. These were (a) a detailed geological study of the three-dimensional geometry of the uranium-bearing rocks, (b) the collection of samples from outcrop transects and drill core according to planned systematic geostatistical procedures, (c) the transformation of the assay values to unleached equivalents, the development of resource estimates by kriging, and the reverse transformation to leached uranium endowment, and (d) the integrated geological and statistical interpretation of these results to produce final resource estimates and error predictions.

3. Leaching was carefully studied so that the outcrop assay data could be converted to unleached equivalent $\mathrm{U}_{3} \mathrm{O}_{8}$ content and then be used to predict the uranium endowment at depth where little data was available. Leaching was found to be negligible at depths greater than 154 feet. The amount of leaching in outcrop: samples was found to be somewhat less than that at 50 feet or so.

4. The geostatistical methodology used in the assessment is outllned in detail. The only trend found to be significant in the deposits was that due to leaching. This nonstationarity was removed by transformation to equivalent uilleached $U_{3}{ }^{0}$. The rcsulting 
stationary regionalized variable was analyzed by a type of optimal weighed averaging called kriging. This produced estimates of the average accumulation over the test area and predictions of the probable error of these averages. The sampling was so designed that the kriging procedure reduced to ordinary arithmetlc averaging. Upper bounds to the estimate error was determined by the kriging mathematlcs. Derlvations of the mathematlcal formulas used are given in Appendix $A$.

5. As an interesting additional resource assessment, the endowment of thorium for exceedances of $100 \mathrm{ppm}$ was also calculated for 'the study areas. The same geostatistical procedures were used, except that the leaching adjustment and reverse transformation was unnecessary.

6. The uranium endowment was computed as 442 tons $\pm 53 \%$ for the Deep Gulch Formation in the Sierra Madre, and as 3,418 tons $\pm 17 \%$ for the Magnolia Formation of the Medicine Bow Mountains. The corresponding thorium endowment was 6,353 tons $\doteq 16 \%$ for the Sierra Madre and 1,996 tons $\pm 15 \%$ for the Medicine Bow Mountains. The errors stated here are probable errors. The actual error has a probablllty of $50 \%$ of being larger than this and $50 \%$ of being smaller. A $90 \%$ confidence interval would be 2.96 times this probable error.

7. The gcological model used in the analysis involved subjective interpretations of the various sources of geological information. In general, the interpretations made were chosen to be slightly 
conservative. A careful analysis of the amount the resource might change under various alternative interpretations is outlined. The basic conclusions are presented in Tables 18, 19, and 20. In the Medicine Bows, under the most pessimistic interpretation the resource could be about half the value calculated in the current investigation and under the most optimistic interpretation, it might be four times larger than that calculated. Similarly in the Sierra Madre, the most pessimistic interpretation would yield a reduction by $80 \%$ of the current reserve estimation, and the most optimistic version would increase the estimation up to a factor of 3 .

8. The relations developed from the study of leaching have significant bearing on various geological questions concerning the two areas. The substantial difference between the leaching relations suggest that mineralogical differences, age differences, depositional history, or other factors may distingulsh the two areas. 


\section{THIS PAGE}

\section{WAS INTENTIONALLY \\ LEFT BLANK}




\section{REFERENCES CITED}

David, M., 1977, Geostatistical Ore Reserve Estimation, Elsevier, Ams terdam, $364 \mathrm{p}$.

Graff, P., 1979, A Review of the stratigraphy and uranium potential of early Proterozoic (Precambrian $X$ ) metasediments in the Sierra Madre, Wyoming: Contributions to Geology, v. 17, no. 2, p. 149-157.

Gumbel, E. J., 1954, Statistical theory of extreme values and some practical applications: Applied Math Series 33, National Bureau Standards, Washington, D. C.

Houston, R. S., and Karistrom, K. E., 1980, Precambrian uranium-bearing quartz-pebble conglomerates: exploration model and United States resource potential: Bendix Field Engineering Corporation Open File Report CJBX $(80-1), 510 \mathrm{p}$.

Journel, A. G. and Huljbregts, Ch., 1978, Mining Geostatistics, Academic Press, New York, $600 \mathrm{p}$.

Karlstrom, K. E. and Houston, R. S.,. 1979, Stratigraphy of the Phantom Lake Metamorphic Suite and Deep Lake Group and a review of the Precambrian tectonic history of the Medicine Bow Mountains: Contributions to Geology, v. 17, no. 2, p. 111-133. 
THIS PAGE

\section{WAS INTENTIONALLY \\ LEFT BLANK}




\section{APPENDIX A}

Mathematical Derivations 


\section{APPENDIX - DERIVATIONS}

\section{Definition $A-1$}

A radial, transitive variogram with elliptical zone of influence is defined as

$$
\gamma\left(h_{1}, h_{2}\right)=\sigma^{2} \text {, for } h_{1}^{2}+h_{2}^{2}>h_{0}^{2}(\theta)
$$

and

$$
\begin{aligned}
\gamma\left(h_{1}, h_{2}\right) & =a^{2}\left\{1-\exp \left[-\left(h_{1}^{2}+h_{2}^{2}\right) / 2 s^{2}(\theta)\right]\right\} \\
& +\left(\sigma^{2}-a^{2}\right) \sqrt{h_{1}^{2}+h_{2}^{2}} / h_{0}(\theta)
\end{aligned}
$$

for $h_{1}^{2}+h_{1}^{2} \leq h_{0}^{2}(\theta)$,

where

$$
\begin{aligned}
& \theta-\arctan \left(h_{2} / h_{1}\right) \\
& s^{2}(\theta)=A^{2} B^{2} /\left[A^{2} \sin ^{2}(\theta-\psi)+B^{2} \cos ^{2}(\theta-\psi)\right] \\
& h_{0}^{2}(\theta)=a^{2} b^{2} /\left[a^{2} \sin ^{2}(\theta-\psi)+b^{2} \cos ^{2}(\theta-\psi)\right]
\end{aligned}
$$

and $s(\theta)$ is small compared with the scale of measurement of $h_{1}$, and $h_{2}$. Both $s(\theta)$ and $h_{0}(\theta)$ define ellipses with long axes in the $\psi$ and $\psi$ angular directions in $\left(h_{1}, h_{2}\right)$ space.

The covariance function corresponding to this variogram is zero for $h_{i}^{2}+h_{2}^{2}>h_{o}^{2}(\theta)$ and

$$
\begin{aligned}
c\left(h_{1}, h_{2}\right) & =a^{2} \exp \left[-\left(h_{1}^{2}+h_{2}^{2}\right) / 2 s^{2}(\theta)\right] \\
& +\left(\sigma^{2}-a^{2}\right)\left[1-\sqrt{h_{1}^{2}+h_{2}^{2}} / h_{0}(\theta)\right]
\end{aligned}
$$


for $h_{1}^{2}+h_{2}^{2} \leq h_{0}^{2}(\theta)$

\section{Definition $A-2$}

Let $V(x, y)$ be some resource variable of economic interest at location $(x, y)$. Let $B$ specify some area within which the average value of $V(x, y)$, denoted by $\bar{V}_{B}$, is of importance.

stated in formulas

$$
\bar{V}_{B}=(1 / B) \int_{B} \int V(x, y) d x d y
$$

where $B$ is also interpreted as the area of $B$ where that is appropriate. The expression, $V(x, y)$, will be considered a stationary random function with variogram $\gamma\left(h_{1}, h_{2}\right)$, covariance $C\left(h_{1}, h_{2}\right)$, and mean $\mu$.

\section{Theorem A-3}

The theoretical mean of $\bar{V}_{B}$ is given by

$$
\sigma_{B}^{2}=\operatorname{Variance}\left[\bar{V}_{B}\right]=(1 / B)^{2} \int_{B} \iint_{B} \int C\left(x-x^{\prime} ; y-y^{\prime}\right) d x d y d x^{\prime} d y^{\prime} \text {. }
$$

\section{Proof}

$$
\begin{aligned}
E\left[\bar{V}_{B}\right] & =E\left[(1 / B) \int_{B} \int V(x, y) d x d y\right] \\
& =(1 / B) \int_{B} \int \mu d x d y=\mu .
\end{aligned}
$$

$$
\text { Veriance } \begin{aligned}
{\left[\bar{V}_{B}\right] } & =E\left[\left\{(1 / B) \int_{B} \int V(x, y) d x d y-\mu\right\}^{2}\right] \\
& =E\left[(1 / B)^{2} \int_{B} \iint_{B} f\{V(x, y)-\mu\}\left\{V\left(x ; y^{\prime}\right)-\mu\right\} d x d y d x^{\prime} d y^{\prime}\right] \\
& =(1 / B)^{2} \int_{B} \iint_{B} \int C\left(x-x^{\prime}, y-y^{\prime}\right) d x d y d x^{\prime} d y^{\prime} .
\end{aligned}
$$


Definition $A-4$

Suppose that the value of $V(x, y)$ is known by sampling at the points $\left(x_{1}, y_{1}\right),\left(x_{2}, y_{2}\right), \ldots,\left(x_{n}, y_{n}\right)$. A reasonable estimate $\hat{\bar{v}}_{B}$ of the quantity $\bar{V}_{B}$ is provided by a linear combination of the sample values

$$
\hat{\bar{V}}_{B}=\sum_{i=1}^{n} a_{i} v\left(x_{i}, y_{i}\right)
$$

It seems reasonable to require that $\hat{\bar{V}}_{B}$ be an unbiased estimate. This condition implies that

$$
\sum_{1} a_{1}-1.0
$$

because

$$
\mu=E\left[\hat{\bar{V}}_{B}\right]=\sum_{i=1}^{n} a_{i} E\left[V\left(x_{i}, y_{i}\right)\right]=\sum_{i=1}^{n} a_{i} \mu
$$

Theorem A-5 (David, 1977; Journel and Huljbregts, 1978)

The constants $\hat{a}_{i} ; i=1,2, \ldots, n$, which minimize the estimation crror variance, $\sigma_{E}^{2}$, defined by

$$
\sigma_{E}^{2}=E\left[\left(\hat{\bar{V}}_{B}-\bar{V}_{B}\right)^{2}\right]
$$

subject to the side condition

$$
\sum_{i=1}^{n} \hat{a}_{i}=1.0
$$


are the solution to the matrix equation

$$
\left[\begin{array}{cccccc}
c_{11} & c_{12} & c_{13} & \cdots & c_{1 n} & 1 \\
c_{21} & c_{22} & c_{23} & \cdots & c_{2 n} & 1 \\
c_{31} & c_{32} & c_{33} & \cdots & c_{3 n} & 1 \\
\cdot & \cdot & \cdot & & \cdot & \cdot \\
c_{n 1} & c_{n 2} & c_{n 3} & \cdots & c_{n n} & 1 \\
1 & 1 & 1 & \cdots & 1 & 0
\end{array}\right] \times\left[\begin{array}{c}
\hat{a}_{1} \\
\hat{a}_{2} \\
\hat{a}_{3} \\
\cdot \\
\cdot \\
a_{n} \\
\hat{u}_{1}
\end{array}\right]=\left[\begin{array}{c}
c_{B 1} \\
c_{B 2} \\
c_{B 3} \\
\cdot \\
\cdot \\
c_{B n} \\
1
\end{array}\right]
$$

where

$$
c_{i j}=c\left(x_{i}-x_{j}, y_{i}-y_{j}\right)
$$

and

$$
C_{B i}=(1 / B) \int_{B} \int C\left(x-x_{i}, y-y_{i}\right) d x d y
$$

An estimate of the estimation error variance is given by

$$
\hat{\sigma}_{E}^{2}=c_{B B}-\hat{\Sigma}_{i} \hat{a}_{i} c_{B i}=\hat{u}
$$

where

$$
C_{B B}=\sigma_{B}^{2}
$$

defined in $(A-3)$.

\section{Proof}

By the method of Lagrangian multipliers, $\hat{a}_{i}$, will be the result of minimizing $Q$ where

$$
Q=\sigma_{E}^{2}+2 u\left(\stackrel{\sum}{n}_{1} a_{i}-1.0\right)
$$


with the added condition that

$$
{\stackrel{n}{\Sigma_{1}}}_{=} a_{i}=.1 .0
$$

Now

$$
\begin{aligned}
& Q=E\left[\left\{\sum_{i} \sum_{1} a_{i} V\left(x_{i}, y_{i}\right)-(1 / B) \delta_{B} \int V(x, y) d x d y\right\}^{2}\right] \\
& +2 u\left(\stackrel{n}{\left.\stackrel{\sum_{1}}{=} a_{i}-1.0\right)}\right. \\
& =E\left[\left\{_{i} \sum_{i}^{n} a_{i}<V\left(x_{i}, y_{i}\right)-1.1>-\left(1 / B f_{B} f<V(x, y)-\mu>d x d y\right\}^{2}\right]\right. \\
& +2 u\left(\sum_{i=1}^{n} a_{i}-1.0\right) \\
& =\sum_{i=1}^{n} \sum_{j=1}^{n} a_{i} a_{j} c_{i j}-2 \sum_{i=1}^{n} a_{i} C_{B i}+C_{B B} \\
& +2 u\left(\sum_{i=1}^{n} a_{i}-1.0\right) \text {. }
\end{aligned}
$$

Consequently

$$
\frac{\partial Q}{\partial a_{k}}=2 \sum_{i=1}^{n} a_{i} c_{k i}-2 C_{B k}+2 u \text {. }
$$

If $\hat{a}_{i}$ and $\hat{u}_{i}$ are the values which make $\partial Q / \partial a_{k}=0$, then

$$
i_{i=1}^{n} c_{k i} \hat{a}_{j}+\hat{u}=c_{B k}
$$

for $k=1,2, \ldots, n$. This. system of simultaneous equations corresponds to the matrix equation stated in the theorem. 
The value of $\hat{Q}$ when $\hat{a}_{i}$ and $\hat{u}$ are substituted into the formula gives a reasonable estimate of $\sigma_{E}^{2}$ as.

$$
\hat{\sigma}_{E}^{2}=\sum_{i=1}^{n} \sum_{j=1}^{n} \hat{a}_{i} \hat{a}_{j} c_{i j}-2 \sum_{i=1}^{n} \hat{a}_{i} c_{B i}+c_{B B}
$$

This formula can be simplified by multiplying both sides of eq. (A-25) by $\hat{a}_{k}$ and summing over $k=1,2, \ldots, n$.

This gives

$$
\sum_{k=1}^{n} \hat{\Sigma}_{i} C_{k i} \hat{a}_{i} \hat{a}_{k}+\hat{u}_{k=1}^{n} \hat{\underline{\Sigma}}_{1} \cdot \hat{a}_{k}=\sum_{k=1}^{n} \hat{a}_{k} C_{B k} \cdot
$$

Since $\sum_{k=1}^{n} \hat{a}_{k}=1.0$, the previous equation can be substituted into eq. $(A-26)$ to yield

$$
\hat{\sigma}_{E}^{2}=c_{B B}-\hat{\Sigma}_{i=1} \hat{a}_{i} C_{B i}-\hat{u}
$$

Theorem A-6

Suppose that

$$
c_{i j}= \begin{cases}\sigma^{2}, & \text { if } i=j \\ 0, & \text { if } i \neq j\end{cases}
$$

and that the indices $i=1,2, \ldots, n$ can be divided into two sets, $s_{1}=$ $\{i ; 1 \leq i \leq m\}$ and $s_{2}=\{i ; m<i \leq n\}$ such that

$$
\begin{array}{ll}
C_{B i} \neq 0, & \text { if } i \in S_{1} \\
C_{B i}=0 & \text {, if } i \in S_{2}
\end{array}
$$

where the symbol " $\varepsilon$ " should be read as "belongs to". That is samples more than a zone of influence away have subscripts in $S_{2}$, while those within a zone of influence of the block being estimated will have subscripts in $\mathrm{S}_{2}$. 
Under these assumptions, the solution to the martix equation in A-5 is

$$
\begin{aligned}
& \hat{a}_{i}=\left\{\begin{array}{l}
(1 / n)+c_{B i} / \sigma^{2}-\sum_{k=1}^{m} c_{B k} / n \sigma^{2}, \text { if } i \varepsilon S_{1} \\
(1 / n)-\sum_{k=1}^{m} c_{B k} / n \sigma^{2}, \text { if } i \varepsilon S_{2}
\end{array}\right. \\
& \hat{u}=(1 / n) \underset{k=1}{m} c_{B k}-\sigma^{2} / n
\end{aligned}
$$

and

$$
\begin{aligned}
\sigma_{E}^{2}= & \sigma^{2} / n+C_{B B}=(2 / n) \sum_{k=1}^{m} C_{B k}-\sum_{k}^{m} c_{B k}^{2} / \sigma^{2} \\
& +\left({ }_{k=1}^{\prime \prime \prime} C_{B k}\right)^{2} / n \sigma^{2} .
\end{aligned}
$$

\section{Proof}

The inverse of

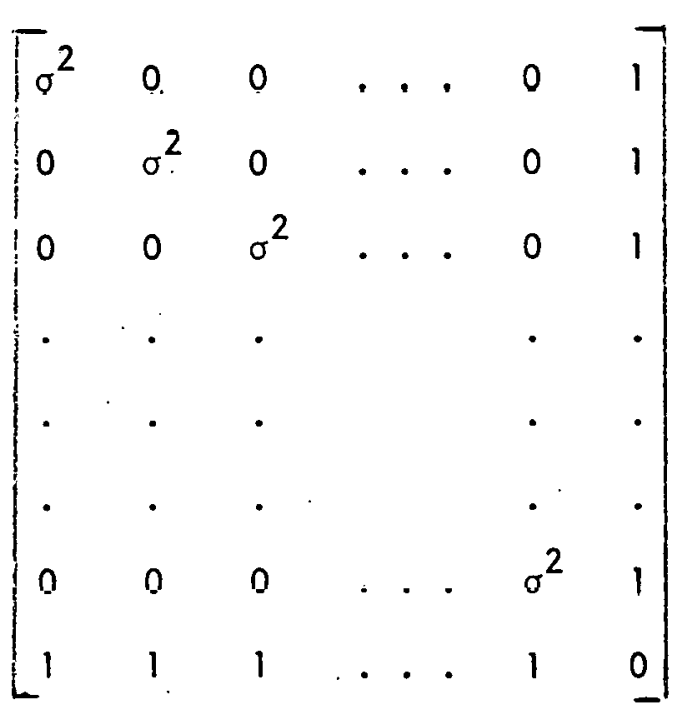


is

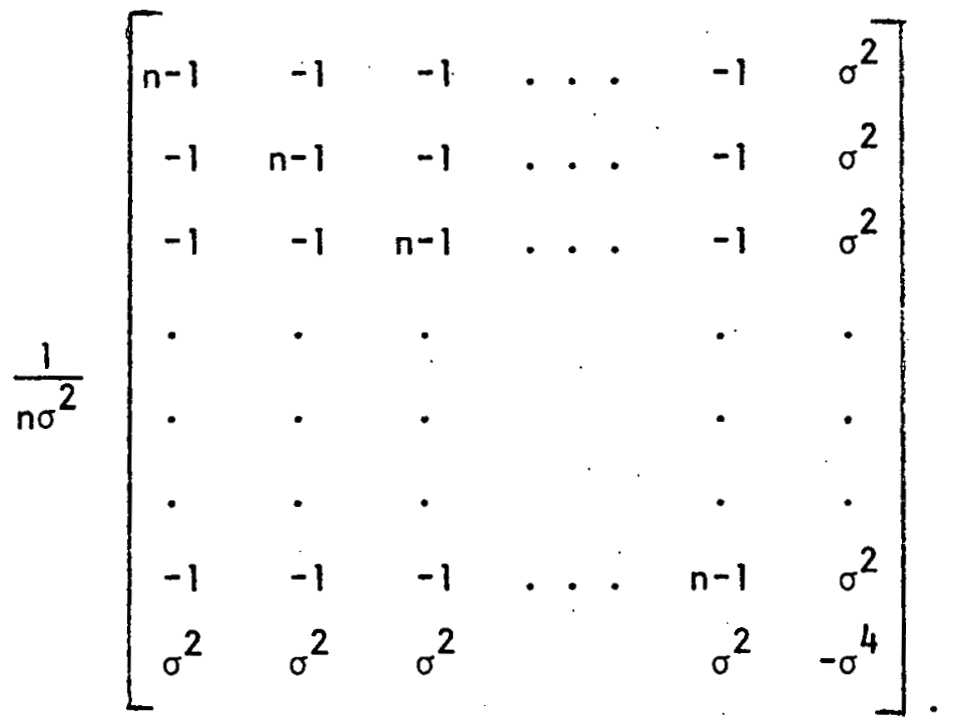

The theorem then tollows from theorem $A-5$.

\section{Theorem A-7}

For the variogram in Definition $(A-1)$, assuming $s(\theta)$ is small enough so that the exponential can be ignored,

$$
\begin{aligned}
0 & \leq C_{B i} \leq \pi a b\left(\sigma^{2}-a^{2}\right) / 3 B \\
C_{B B} & <\pi a b\left(\sigma^{2}-a^{2}\right) / 3 B .
\end{aligned}
$$

An upper bound for $\hat{\sigma}_{E}^{2}$, providing $C_{B} / \sigma^{2}$ is negligible, is ,

$$
\hat{\sigma}_{E}^{2}<\left(\sigma^{2} / n\right)+\pi a b\left(\sigma^{2}-a^{2}\right) / 3 B \text {. }
$$

P.roof

If the elliptical base for the variogram is entirely enclosed within $B$, then

$$
\int_{B} \int C\left(x-x^{\prime}, y-y^{\prime}\right) d x d y=\pi a b\left(\sigma^{2}-a^{2}\right) / 3 .
$$

The rest of the relations follow from theorem $A-6$. 


\section{THIS PAGE \\ WAS INTENTIONALLY \\ LEFT BLANK}




\section{Appendix B}

Detailed Tabulations of Deposit Geometry

Sierra Madre, Unit \#3

Figure

Page

B-1 Carrico Ridge \#1; Inferred geometry A between

Ridge \#1 and \#2............. 109

B-2 Inferred geometry $B$ between Carrico Ridge \#1 and \#2; Carrico Ridge.\#2 .......... 110

B-3 Inferred geometry between Carrico Ridge \#2 and \#3; Carrico Ridge \#3 . . . . . . . . . . 111

B-4 Inferred geometry between Carrico Ridge \#3 and fault; Deep Gulch \#5 .......... 112

B-5 Deep Gulch \#4; Deep Gulch \#3A ........... 113

B-6 Deep Gulch \#3B; Inferred geometry, Deep Gulch \#2............... 114

B-7 Deep Gulch \#1; Inferred geometry between Deep Gulch \#1 and Manning Ridge \#1. . . . . . 115

B-8 Manning Ridge \#I; Inferred geometry between Manning Ridge \#1 and \#2.......... 116

B-9 Manning Ridge \#2A; Manning Ridge \#2B . . . . . . 117

B-10 Inferred geometry between Manning Ridge \#2 $(A, B)$ and \#3; Manning Ridge \#3 ....... 118

B-11 Inferred geometry east of Manning Ridge \#3 . . . . 119

Medicine Bow

Figure Structure contours on top of:

B-12 Hineable Unit 1, overturned west limb, Onemile

Creek area................ 122

B-13 Mineable Unit 1 , overturned southern limb Onemi le Creek area ........... 123

B-14 Principal radioactive unit in Threemile Creek

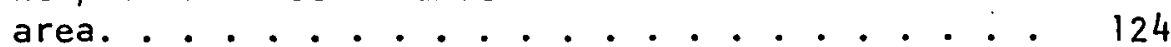

B-15 Mineable units $5 a$ and 5b, eastern synciline, Onemile Creek area............

B-16. Mineable units $5 a$ and $5 b$; east limb of Onemile creek area.............. 126

Table

Summary of areas per depth interval for Sierra

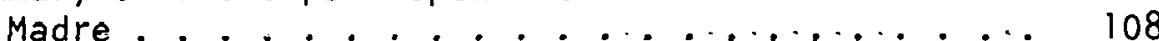

B-2 Summary of areas per depth interval for Medicine Bow . . . . . . . . ......... 
Table B-I

SUMMARY CF AREAS PER DEPT'- INTERVAL FOR SIERRA MACRE

\begin{tabular}{|c|c|c|c|c|c|c|c|c|c|c|c|c|}
\hline Unit 3: Strike Len & Tा & & & & & רno $=0$ & per depth i & nterval (sc & q. Ft.) & & & \\
\hline Segment $A v$ & Av. ET. & $0-130$ & $00-200$ & $200,-300$ & $300-403$ & $400-500$ & $500-1000$ & $1000-1500$ & $1500-2000$ & $2000-3000$ & $3000-4000$ & $4000-5000$ \\
\hline $\begin{array}{l}\text { Carrico Ridge } \\
\text { \#l }\end{array}$ & 7685 & 282523 & 331775 & $331 \div 75$ & 331775 & 0 & 1094512 & 1824187 & $18 \approx 4.187$ & 3648375 & 3648375 & 3648375 \\
\hline $\begin{array}{l}\text { Inferred Geometry } \\
\text { A, Between Carrico } \\
\text { Ridge \#1 and \#2 }\end{array}$ & 7670 & 104738 & 170085 & 170385 & 170085 & 170085 & 850454 & 850154 & $8404+54$ & 1700908 & 1700908 & 1700908 \\
\hline $\begin{array}{l}\text { Inferred Geometry } \\
\text { B, Between Corrico } \\
\text { Ridge \#1 and } \$ 2\end{array}$ & 7772 & 107744 & 123165 & 123165 & $123165^{\circ}$ & 123165 & 615804 & 615804 & $6: 5804$ & 1231692 & 1231692 & 1231692 \\
\hline$\frac{1}{\text { Carrica Ridge }}$ & 7870 & 104739 & 95306 & 95306 & 95306 & 95306 & 476547 & $476 \subseteq 47$ & $4 ? 6547$ & 953095 & 953095 & 953095 \\
\hline $\begin{array}{l}\text { Inferred Geometry } \\
\text { Between Carrico }\end{array}$ & 78333 & 100695 & 115322 & 115322 & 115322 & 115322 & 576286 & $576 \div 886$ & 576286 & 1152573 & 1152573 & 1152573 \\
\hline Carrice Ridge & 7977. & 104839 & 93545 & 93545 & 93545 & 93545 & 467725 & $467: 25$ & 467725 & 935450 & $935450^{\circ}$ & 935450 \\
\hline $\begin{array}{l}\text { Inferred Geometry } \\
\text { Betweer Carricoo } \\
\text { Ridge } 63 \text { and Fault }\end{array}$ & 7835 & $130 E 25$ & 165625 & $16 \$ 25$ & 165625 & 165625 & 828125 & 828125 & 828125 & 1656250 & 1656250 & 1656250 \\
\hline Deep GLICh $\$ 5$ & 7752 & 342428 & 242598 & 242598 & 242598 & $242598^{\circ}$ & 1212863 & $1212 \varepsilon 63$ & 1212863 & 2425726 & 2425726 & 2425726 \\
\hline Deep GLICh H4 & $78 \approx 5$ & $26 \subseteq 72$ & 30525 & 30525 & 30525 & 30525 & 152600 & 1526.00 & 152600 & 305200 & 305200 & 305200 \\
\hline$\overline{\text { Deep GLICh \#3A }}$ & 7821 & $150 E 25$ & 158618 & 158618 & I5861E & 158618 & 793030 & 793030 & 793030 & 1586061 & 1586061 & 1586061 \\
\hline Deep GLIch $\# 38$ & 8005 & 119730 & 86163 & $8 E 163$ & 86163 & 86163 & 430782 & 430.82 & 436782 & 861564 & 861564 & $86 ! 564$ \\
\hline $\begin{array}{l}\text { Inferred Geometry } \\
\text { Deep Gulch \#2 }\end{array}$ & 8041 & 163125 & 163187 & 163187 & 163187 & 163187 & 815875 & 815675 & 815875 & 1631750 & 1631750 & 1631750 \\
\hline Deep Gulch $\# 1$ & 797 & $152 C 73$ & 132232 & 132232 & 132232 & 132232 & 661138 & $661 \cdot 38$ & 13.22277 & 1322277 & 1322277 & 1322277 \\
\hline $\begin{array}{l}\text { Inferred Geometry } \\
\text { Betweer Deep Gulch } \\
\# 1 \text { and Manning } \\
\text { Ridge } \hbar 1\end{array}$ & 7948 & $552 \varepsilon 75$ & 583406 & 583406 & $58340 \epsilon$ & 583406 & 2916937 & 2916937 & $291 \in 937$ & 5833875 & 5833875 & 5833875 \\
\hline$\overline{M a n n i n g ~ R i d g e ~} \# 1$ & $79 \in 0$ & $146 \epsilon .16$ & 112014 & 112014 & 112015 & 112014 & 560088 & $560 \omega \varepsilon .8$ & $55 \cos 8$ & 11201.76 & 1120176 & 1120176 \\
\hline $\begin{array}{l}\text { Inferred Geometry } \\
\text { Between Manning } \\
\text { Ridge } A 1 \text { and } \sharp 2\end{array}$ & $783: 9$ & $193: 37$ & 194459 & 194459 & $19445 \mathrm{C}$ & 194459 & 972262 & 97226.2 & 975262 & 1944525 & 1944525 & 1944525 \\
\hline Manning RIdge $\$ 2 A$ & $79 ; 7$ & 103664 & 81983 & 81983 & $8198=$ & 81983 & 410118 & 41018 & 410.118 & 820236 & 820236. & 820236 \\
\hline Manning Ridge $\# 2 B$ & 79,7 & $11+22$ & 97583 & 97583 & $9758 \equiv$ & 97583 & 487899 & 487899 & $43: 899$ & 975798 & 975798 & 975798 \\
\hline Tnferred Geometry & $7 £: 2$ & 169246 & 196581 & $19 \in 581$ & 196581 & 982869 & 982869 & 983389 & $98: 869$ & 1965738 & 1965738 & 1965738 \\
\hline $\begin{array}{l}\text { Between Manning } \\
\text { Ridge } \$ 2 \text { and } \# 3 \\
\text { Manning Ridge } \# 3\end{array}$ & $8 C 60$ & 44549 & 44549 & $4 \& 545$ & 44549 & 44549 & 222736 & 222736 & $22: 736$ & 445473 & 445473 & 445473 \\
\hline $\begin{array}{l}\text { Inferred Geometry } \\
\text { Between Manning } \\
\text { Ridge } 73 \text { and Fault }\end{array}$ & 7595 & 12730 & 141425 & $14: 425$ & 141425 & 141425 & 707100 & 707100 & $70: 100$ & 1414200 & 1414200 & 1414200 \\
\hline $\begin{array}{l}\text { Total Area for Inte } \\
\text { Cumula: ive Area } \\
\end{array}$ & tervals & $\begin{array}{l}3343065 \\
3343065\end{array}$ & $\begin{array}{l}3360148 \\
6703213\end{array}$ & $\begin{array}{r}.3360148 \\
10065-361 \\
\end{array}$ & $\begin{array}{r}3360148 \\
13423509 \\
\end{array}$ & $\begin{array}{r}3028373 \\
16451882 \\
\end{array}$ & $\begin{array}{r}16235753 \\
32687635 \\
\end{array}$ & $\begin{array}{r}16965+28 \\
49653) 64\end{array}$ & $\begin{array}{l}16955428 \\
6.6616492 \\
\end{array}$ & $\frac{33930942}{100549434}$ & 33930942. & $\begin{array}{r}33930842 \\
168411318\end{array}$ \\
\hline
\end{tabular}


Carrico Ridge \# I. Width=2875.

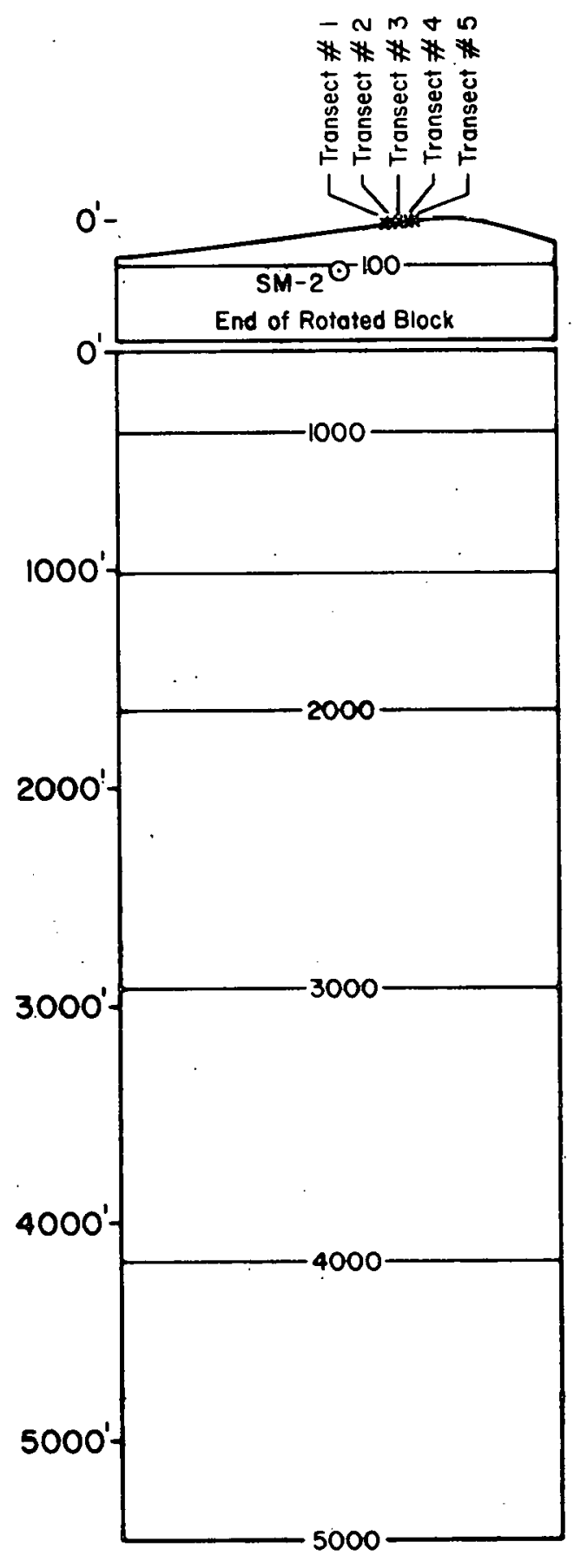

Inferred Geometry, A, Between

Carrico Ridge \# 1 and \# 2 .

Width $=1160^{\prime}$.

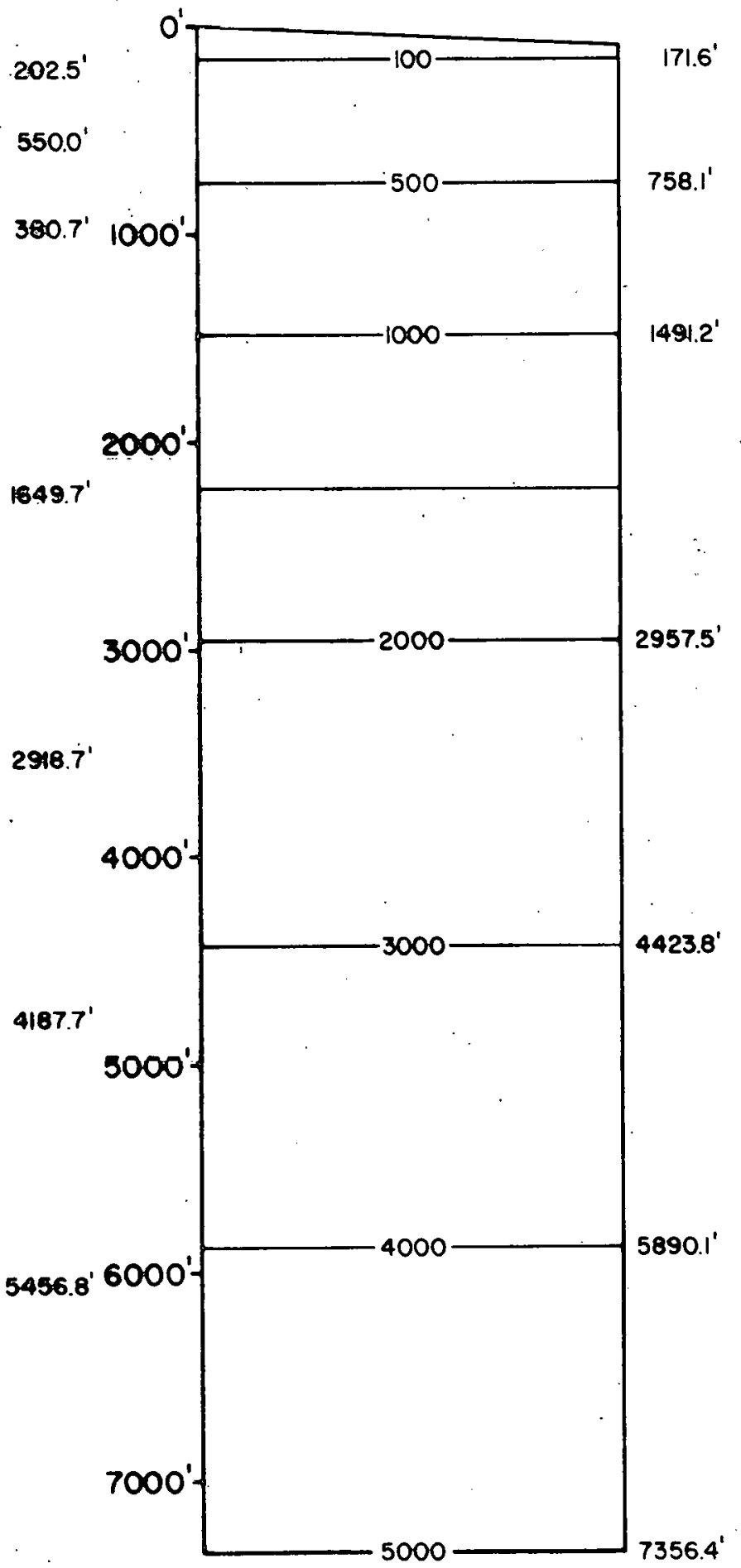

Sierra Madre Unił \# 3

Figure B-1 
Inferred Goometry, B, Between

Carrico Ridge \# 1 and \# 2 .

Width $=840^{\prime}$.
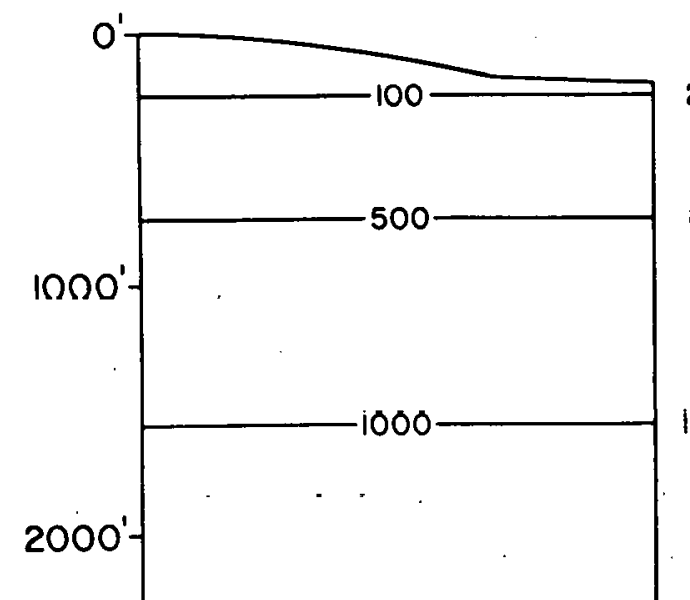

$3000^{\prime}$

$-2000$

$4000^{\prime}$
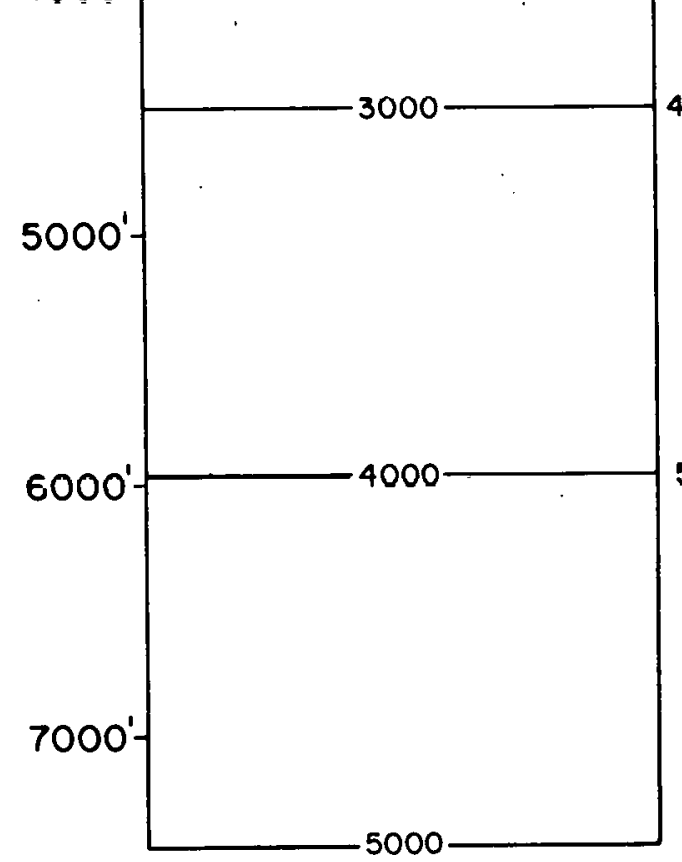

Corrico Ridge \# 2. Width = 650'.

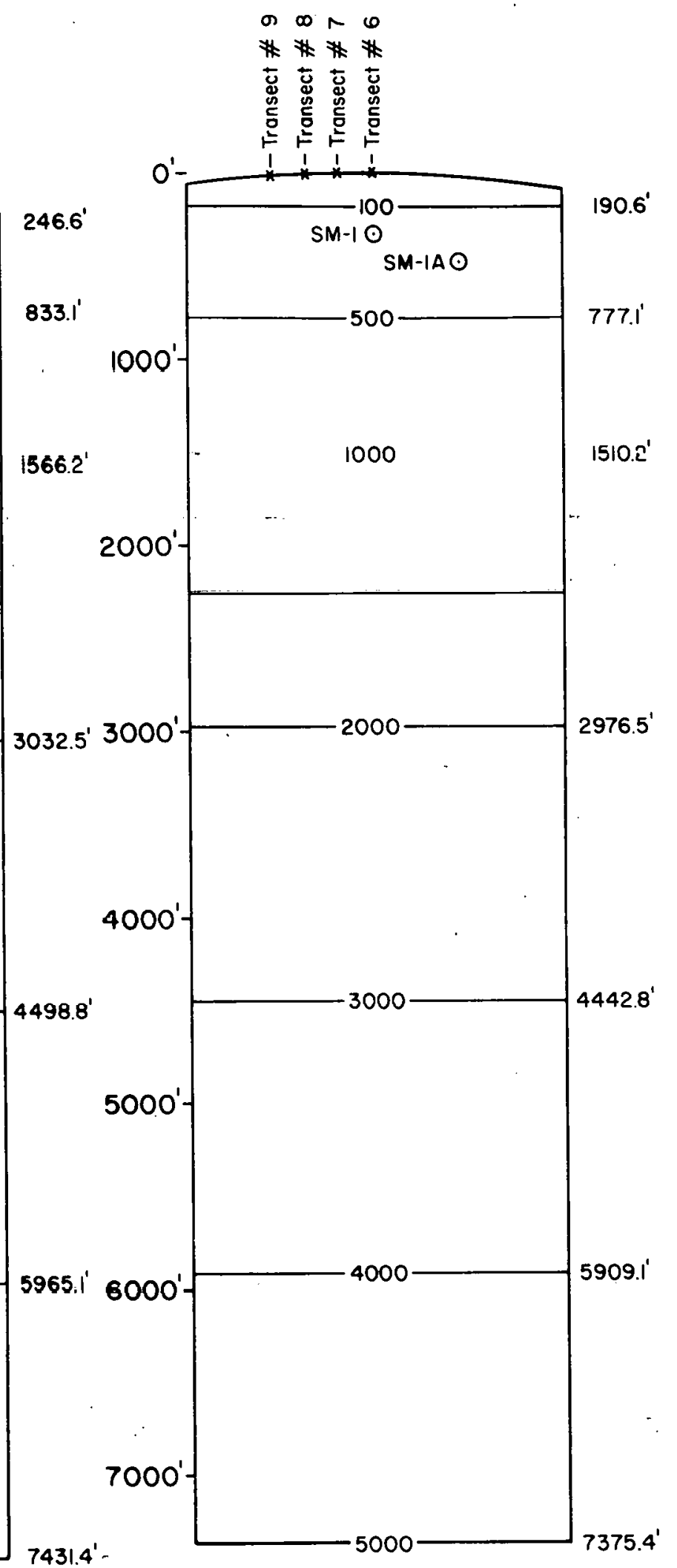

Sierra Madre Unit \# 3

Figure B-2 
Inferred Geometry Between

Carrico Ridge \# 2 and \# 3 .

Width $=815^{\prime}$.
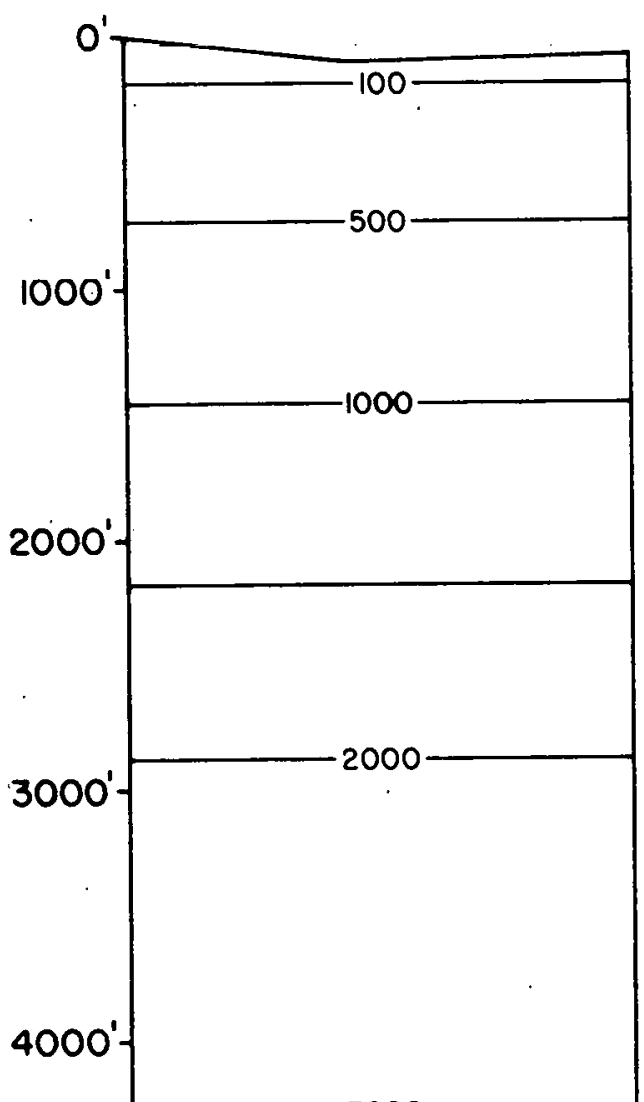

$5000^{\prime}$
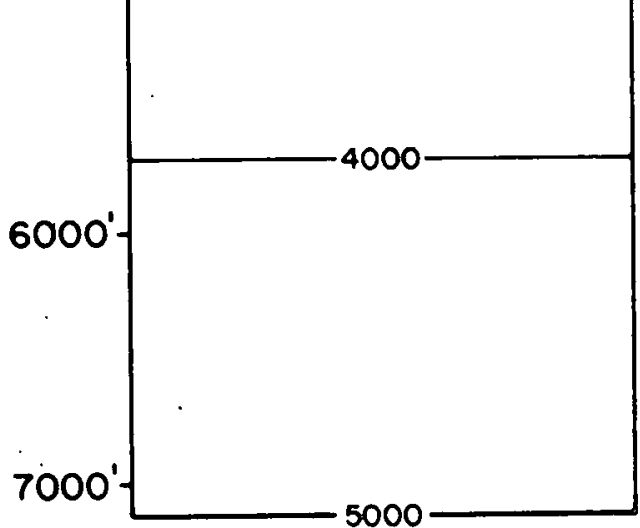

$5706.8^{\prime}$

$6000^{\prime}$

$1464.2^{\prime}$

$2878.4^{\prime}$

.

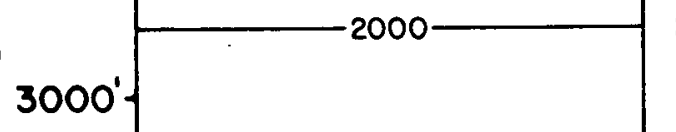

$\underline{N}=$ 으

*

$\overline{\mathrm{g}} \overline{\mathrm{J}}$

总总总

$191.1^{\prime}$

757.1

o'-

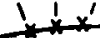

$1+x$
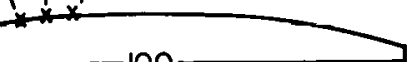

$2000^{\circ}$

$4292.6^{\prime}$

$$
4000^{\prime}
$$

5000

$5688.0^{\circ}$

$7121.6^{1}$

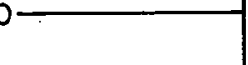

$725.5^{\prime}$

$1000^{\prime}$

1000

$1388.0^{\prime}$

$2713.0^{\prime}$

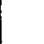

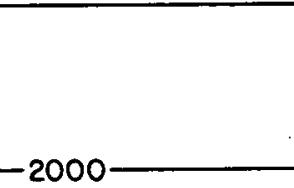

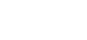

$5363.0^{\prime}$

$95.5^{\prime}$

$4038.0^{\prime}$

$5000^{\circ}$

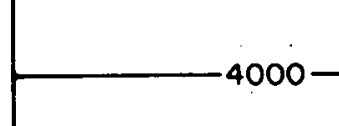

Sierra Madre Unit \# 3

Figure B-3 
Inferred Geometry Between Corrico Ridge \# 3 and fault.

Width $=1250^{\prime}$.

O'-

$0^{\prime-}$

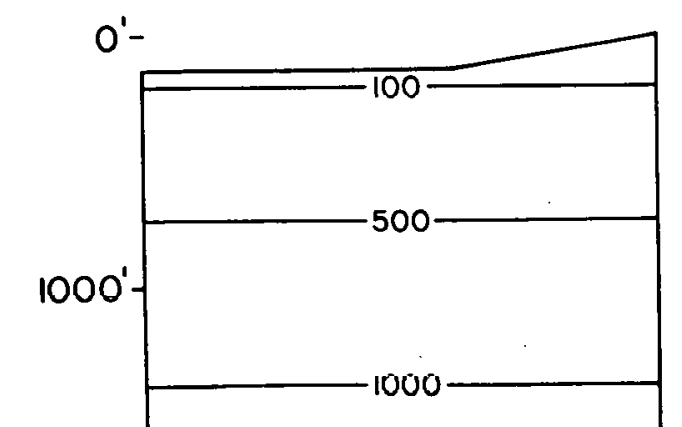

$2000^{\prime}$

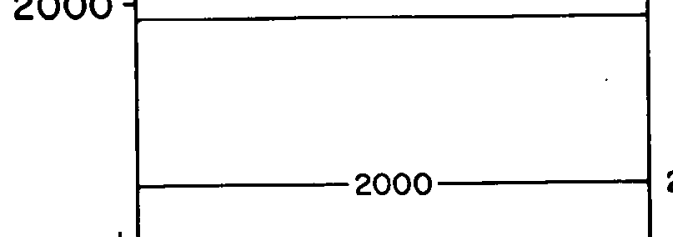

$$
3
$$

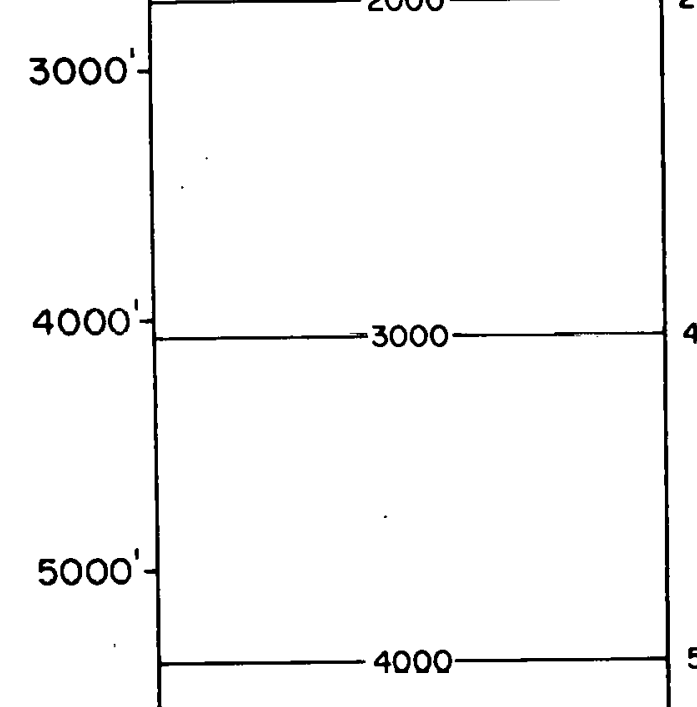

2722.0

$209.5^{1}$

O'-

Deep Gulch \# 5. Width= 1685'.

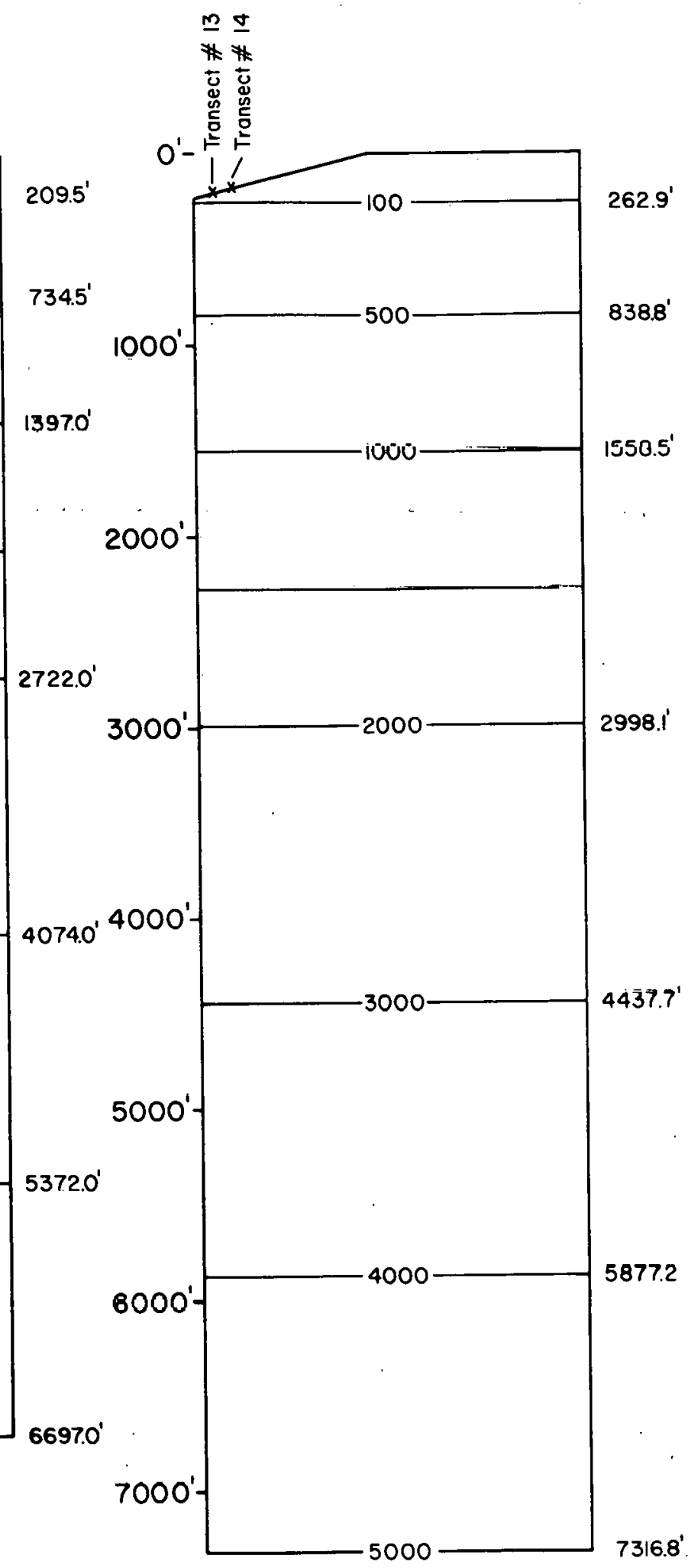

Sierra Madre Unit \# 3

Figure B-4 


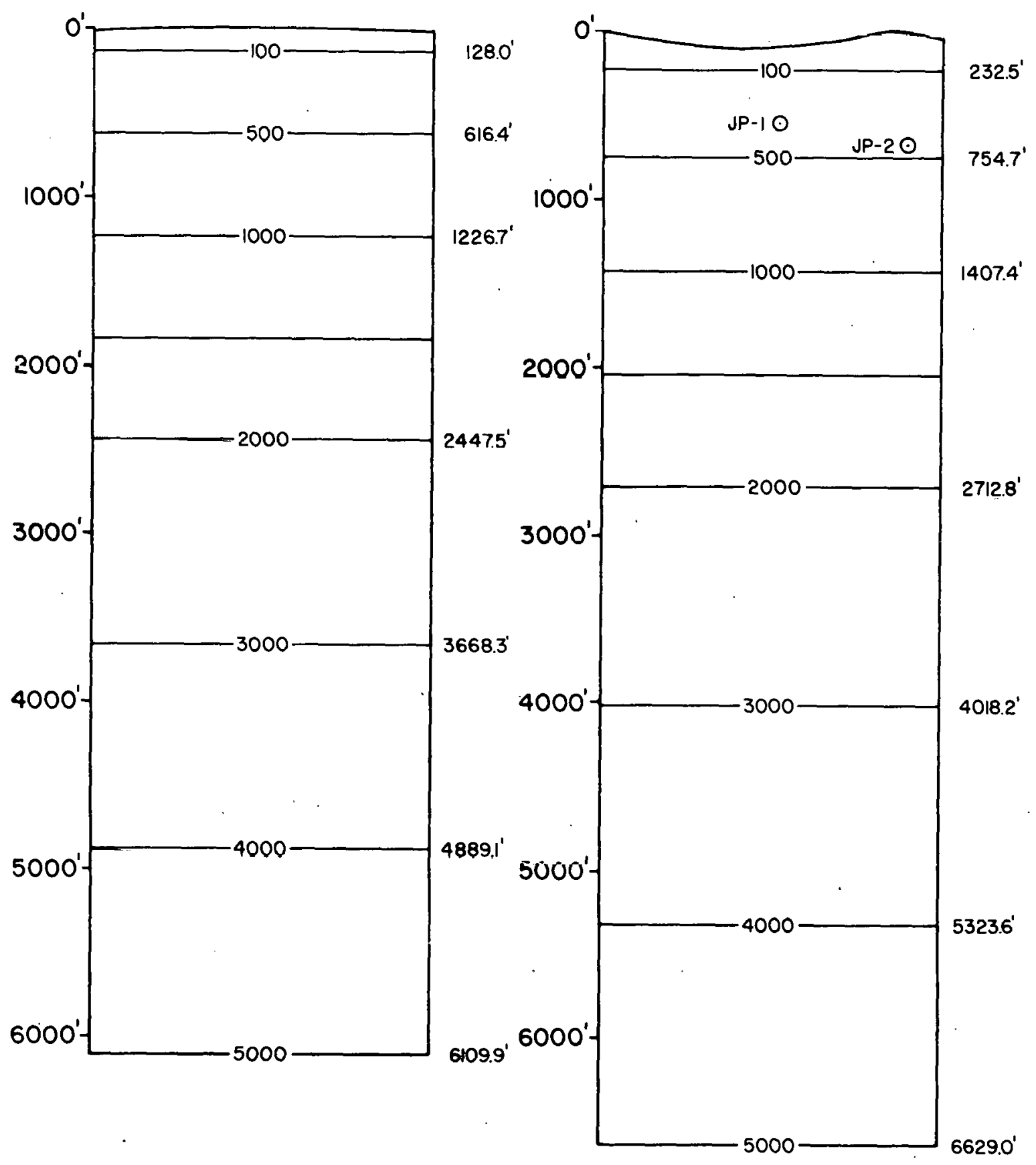

Sierra Madre Unit \# 3

Figure B-5 
Deep Gulch \# 3B. Width 660'.

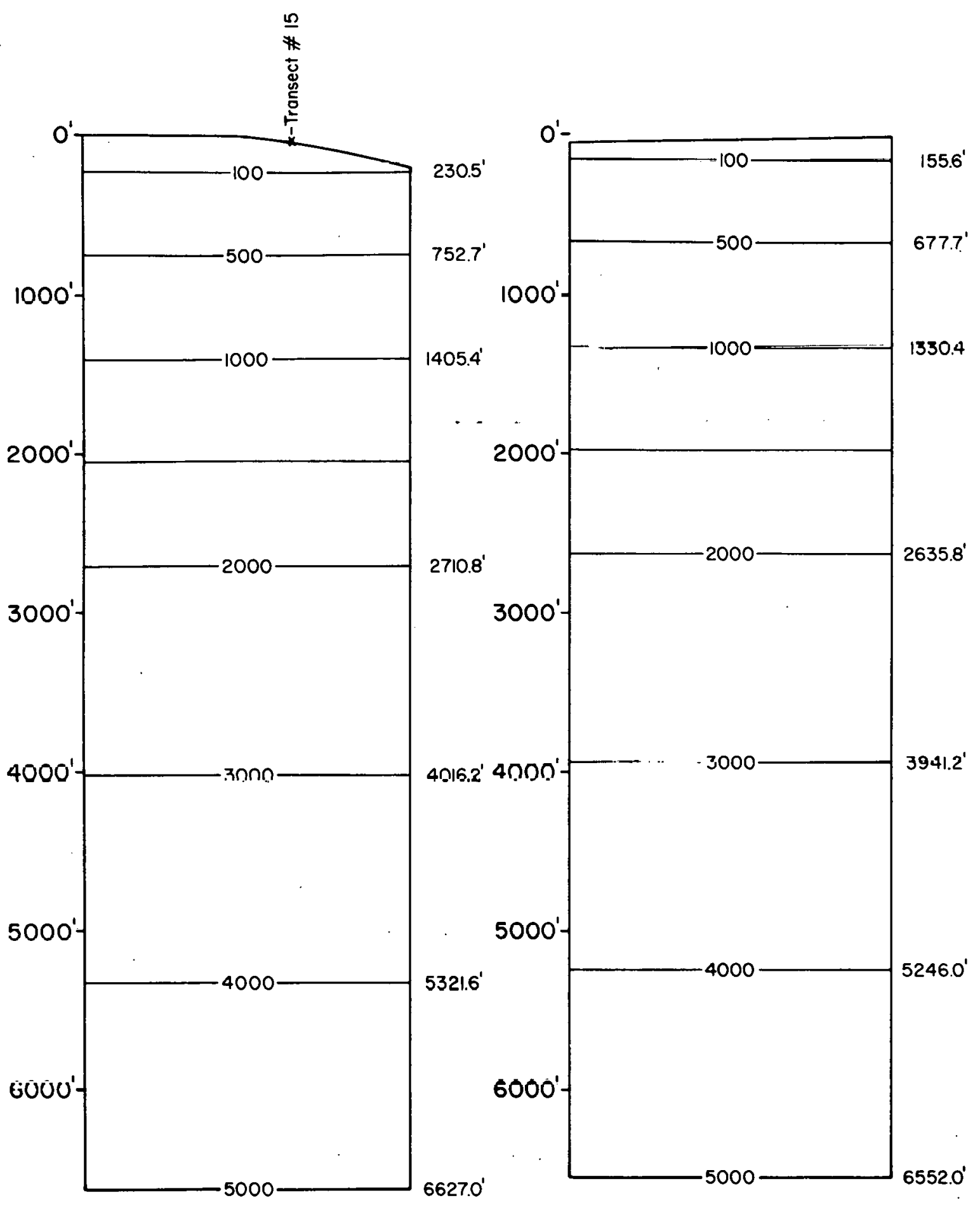

Inferred Geometry, Deep Gulch

\#2. Width $=1250^{\prime}$. 


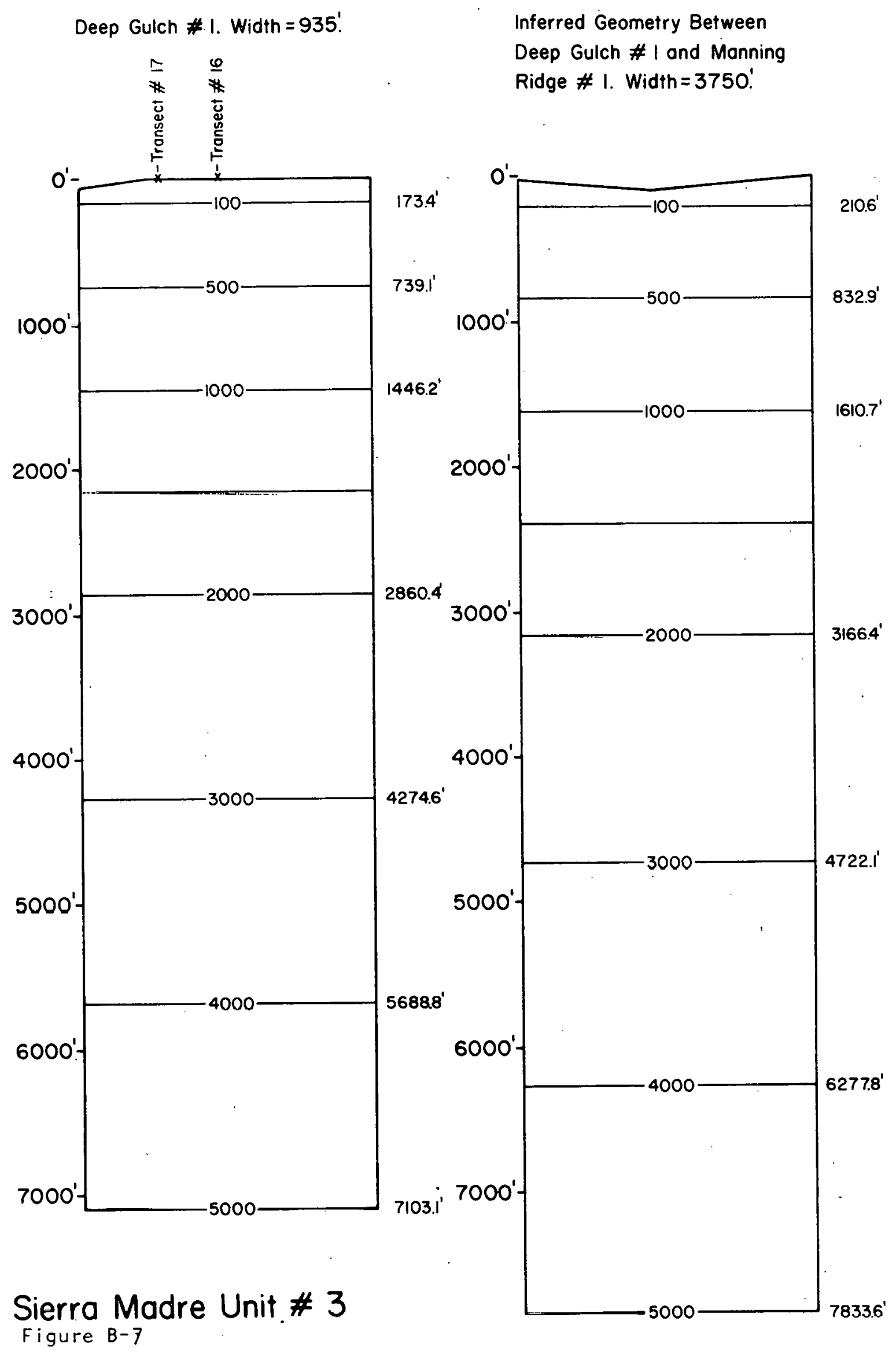




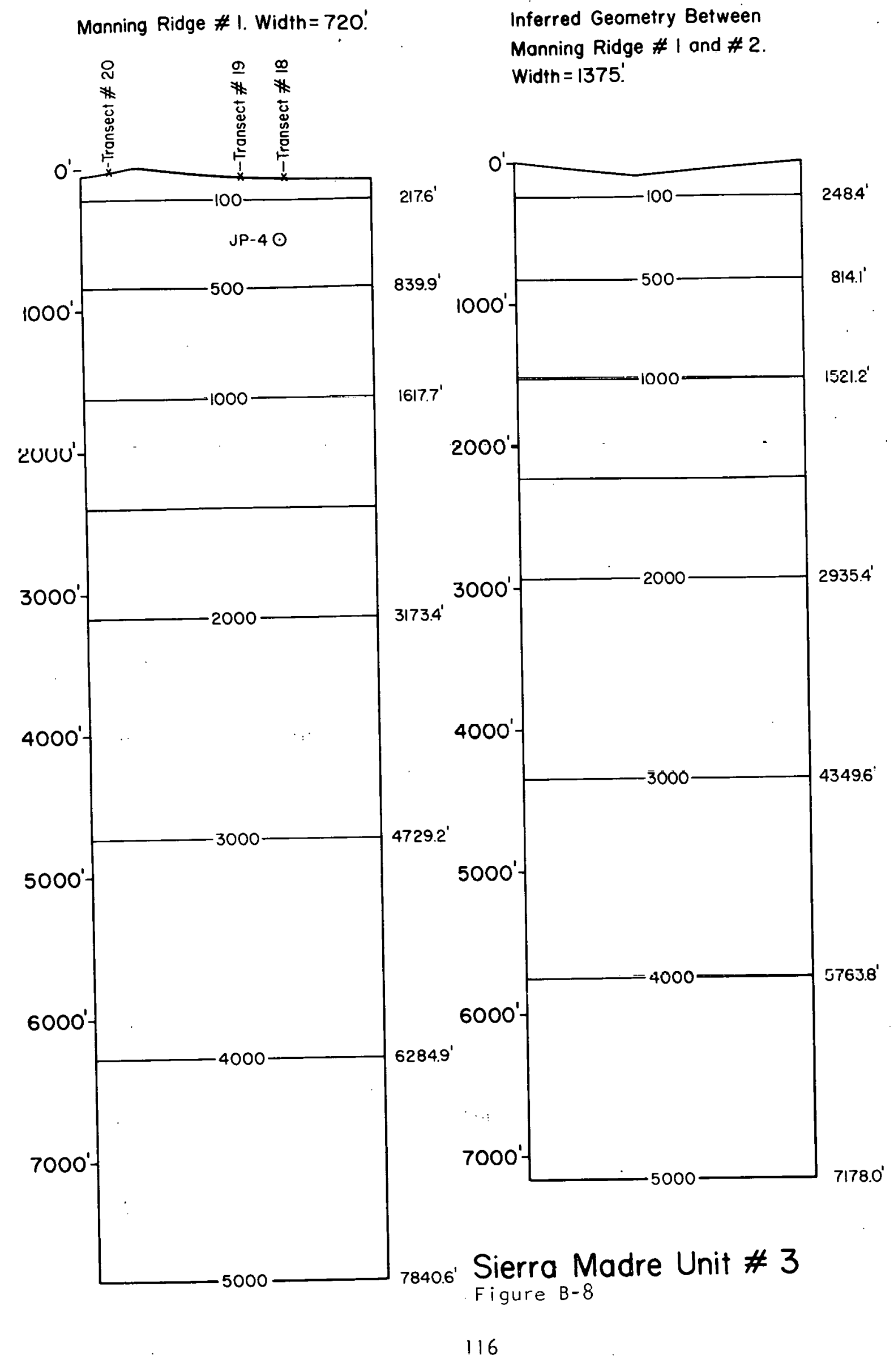




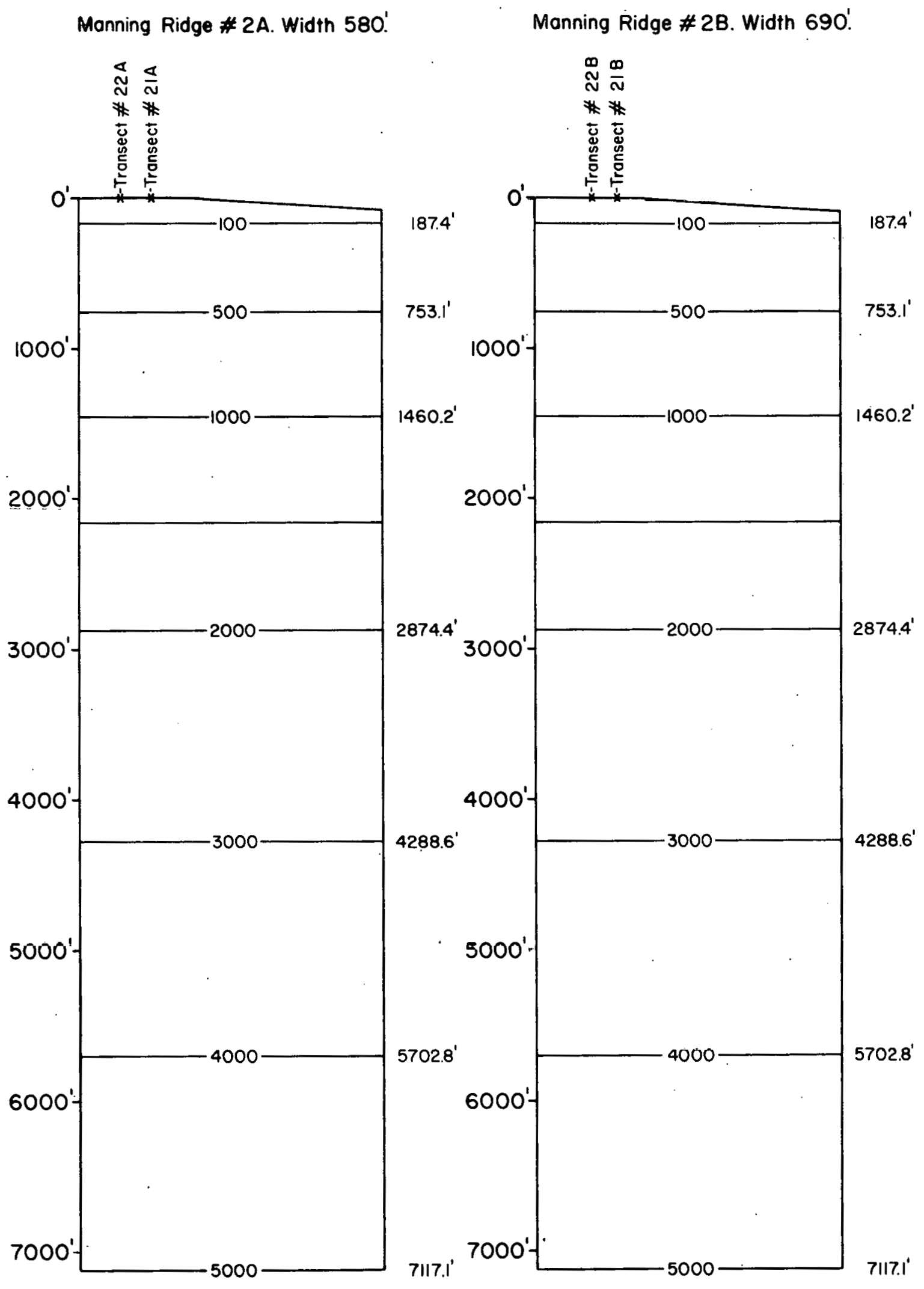

Sierra Madre Unit \# 3

Figure B-9 
Inferred Geometry Between Manning Ridge \# $2(A, B)$ and \#3. Width=1390.'

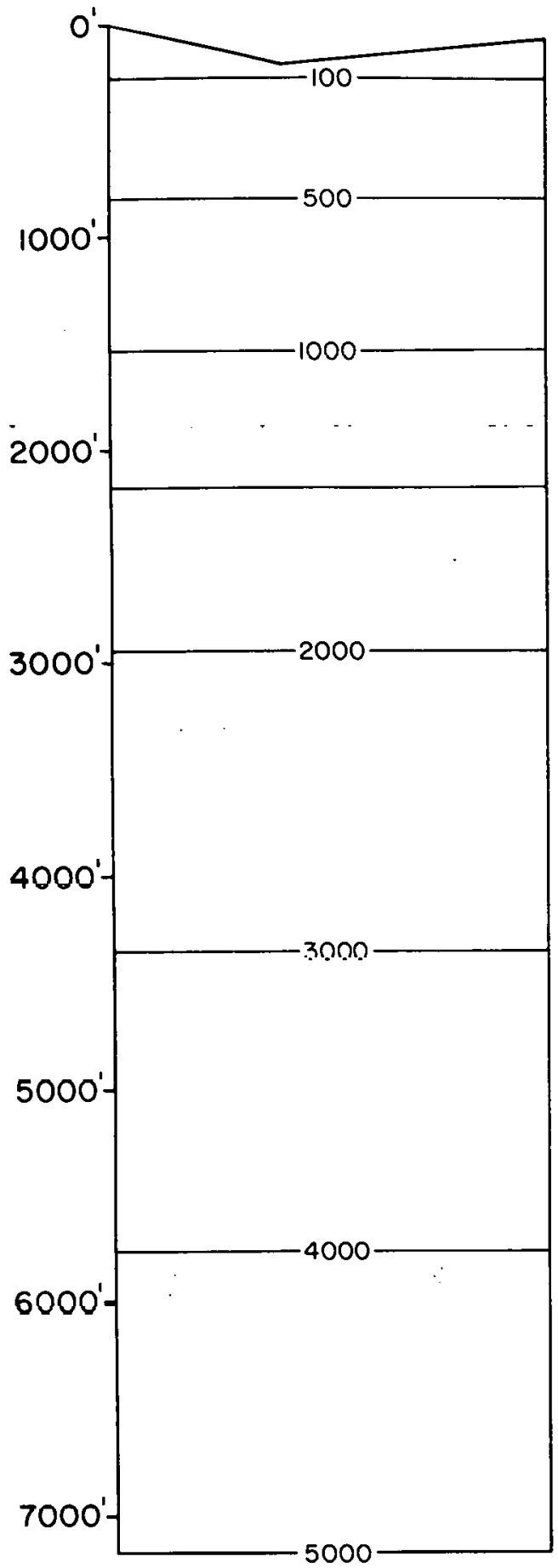

Manning Ridge \# 3. Width $=315$.'

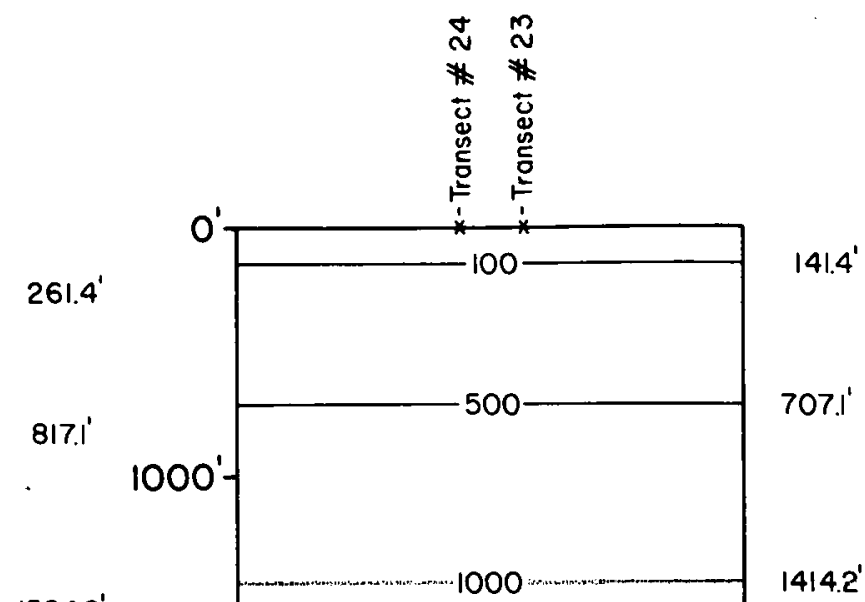

1524.2 2938. $4.3576^{\prime}$ $4000^{\prime}$ 3000 $4^{\prime 2} 24^{\prime} 26^{\prime}$ $5766.8^{\prime}$

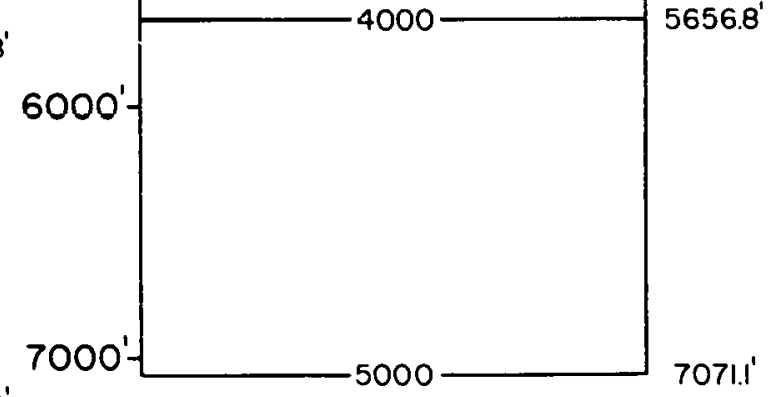

Sierra Madre Unit \# 3

Figure $B-10$ 
Inferred Geometry East of

Manning Ridge \# 3 .

Width = 1000'.

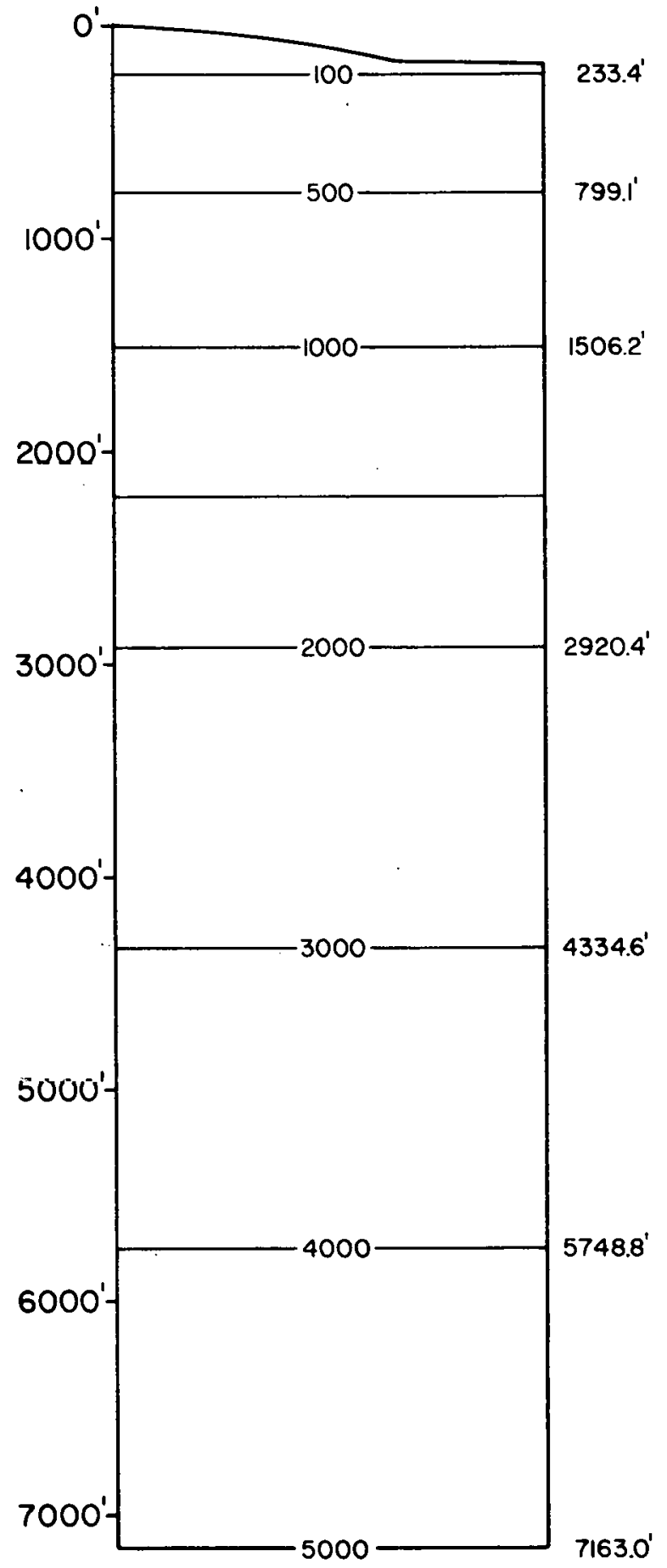

Sierra Madre Unit \#3

Figure $B-11$ 
Table B-2

SUMMARY OT AREAS PER DCPTH INTERVAL FOR MEOICINE BOW

Area per depth interval (sq. ft.)

\begin{tabular}{|c|c|c|c|c|c|c|c|c|}
\hline $\begin{array}{r}\text { SEGMENT } \\
\text { NUMBER } \\
\end{array}$ & $\begin{array}{l}\text { AVE. } \\
\text { EL. }\end{array}$ & $0-100$ & $100-200$ & $200-300$ & $300-400$ & $400-500$ & $500-1000$ & $1000-1500$ \\
\hline \multicolumn{9}{|l|}{ Unit $5 a:$} \\
\hline 1 & 8850 & 43750 & 43750 & 43750 & 56250 & 71320 & 20350 & \\
\hline 2 & 8770 & 64500 & 64500 & . 64500 & 64500 & 64500 & 191350 & \\
\hline 3 & 8710 & 89250 & 89250 & 89250 & 89250 & 144375 & 212250 & \\
\hline 4 & 8700 & 95625 & 95625 & 95625 & 95625 & 147250 & & \\
\hline 5 & 8640 & 42500 & 42500 & 42500 & 42500 & 42500 & 213900 & 5625 \\
\hline 6 & 8600 & 63000 & 63000 & 63000 & 63000 & 63000 & 107250 & 45150 \\
\hline 7 & 8420 & 60000 & 60000 & 60000 & 60000 & GUUUं & 68UUU & . \\
\hline 8 & 8500 & 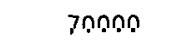 & 7חnח & $7 n n n n$ & $875 n n$ & 36250 & & \\
\hline 9 & 8535 & 78000 & 78000 & 78000 & 78000 & 40000 & 43750 & \\
\hline \multicolumn{9}{|c|}{ Eastern S } \\
\hline 1 & 8420 & 52500 & 52500 & 52500 & $52500^{\circ}$ & 37365 & & \\
\hline 2 & 8450 & 25000 & 25000 & 25000 & 26200 & & & \\
\hline 3 & 8480 & 54375 & 54375 & 87812 & & & & \\
\hline 4 & 8510 & 39375 & 39375 & 39375 & 39375 & 39375 & 303750 & 1,6250 \\
\hline .5 & 8510 & 48000 & 48000 & 48000 & 48000 & 48000 & 435840 & 49890 \\
\hline \multicolumn{9}{|c|}{$\begin{array}{l}\text { (Unit } 5 a \text { totals include both east limb and eastern syncline portions) } \\
\text { Total area }\end{array}$} \\
\hline Cumulat ive & area & 825875 & 1651750 & 2511062 & 3309762 & 4093697 & 5690137 & 5837052 \\
\hline \multicolumn{9}{|c|}{ Unit 5b: East Limb, Strike Length $=3100$ feet } \\
\hline 1 & 8800 & 36000 & 36000 & 36000 & 12750 & & & \\
\hline 2 & 8825 & 38750 & 38750 & 38750 & 46500 & & & \\
\hline 3 & 8760 & 52000 & 52000 & 5,2000 & 52000 & 52000 & 17500 & \\
\hline 4 & 8707 & 78750 & 78750 & 78750 & 78750 & 28500 & & \\
\hline 5 & 8670 & 58750 & 58750 & 58750 & 38750 & & & \\
\hline 6 & 8640 & 26000 & 26000 & 26000 & 26000 & 33250 & 90250 & \\
\hline 7 & 8530 & 102000 & 105000 & 150000 & 180000 & & & . \\
\hline 8 & 8500 & 89250 & 78750 & 57750 & & . & & . \\
\hline 9 & 8500 & 25250 & 25250 & 31500 & & & & \\
\hline \multicolumn{9}{|l|}{ Unit 5b: } \\
\hline 1 & 8660 & 27500 & 25900 & 24000 & 22385 & 16250 & 52650 & \\
\hline 2 & 8595 & 60000 & 60000 & 60000 & 60000 & 60000 & 152500 & \\
\hline 3 & 8555 & 25000 & 25000 & 27400 & 27400 & 27400 & 31620 & . \\
\hline 4 & 8530 & 36000 & 36000 & 36000 & 36000. & 36000 & $2 / \dot{b} \cup u$ & \\
\hline 5 & 8510 & 32750 & 32750 & 39300 & 39300 & 32725 & 6507 & \\
\hline 6 & 8590 & 14170 & 15312 & 6250 & 1875 & & & \\
\hline $\begin{array}{l}\text { (Unit 5b t } \\
\text { Total area } \\
\text { for interv } \\
\end{array}$ & $\begin{array}{l}\text { totals } \\
\text { vals }\end{array}$ & $\begin{array}{r}\text { nclude both } \\
702170 \\
\end{array}$ & $\begin{array}{l}\text { east } 1 \mathrm{imb} \text { and } \\
694212 \\
\end{array}$ & $\begin{array}{l}\text { eastern syn } \\
725450 \\
\end{array}$ & $\begin{array}{l}\text { cline portior } \\
621710\end{array}$ & 286125 & 378627 & \\
\hline Cumulative & e area & 702170 & 1396380 & 2121830 & 2743540 & 3029665 & 3408292 & $\dot{.}$ \\
\hline
\end{tabular}


Table B-2 (continued) is

SUMMARY OF AREAS PER DEPTH INTERVAL FOR MEOICINE BOW

Area per depth interval (sq. ft.)

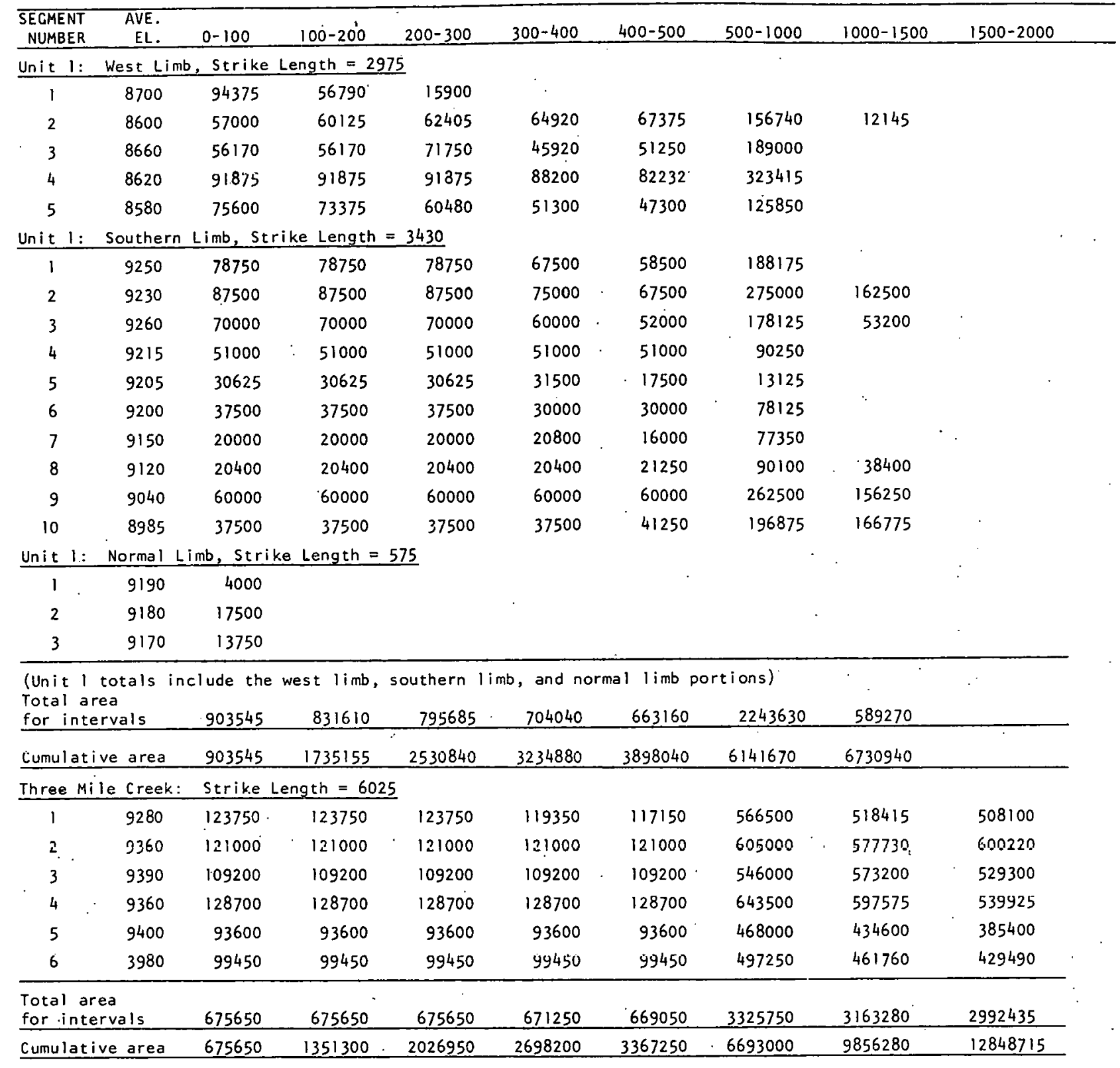




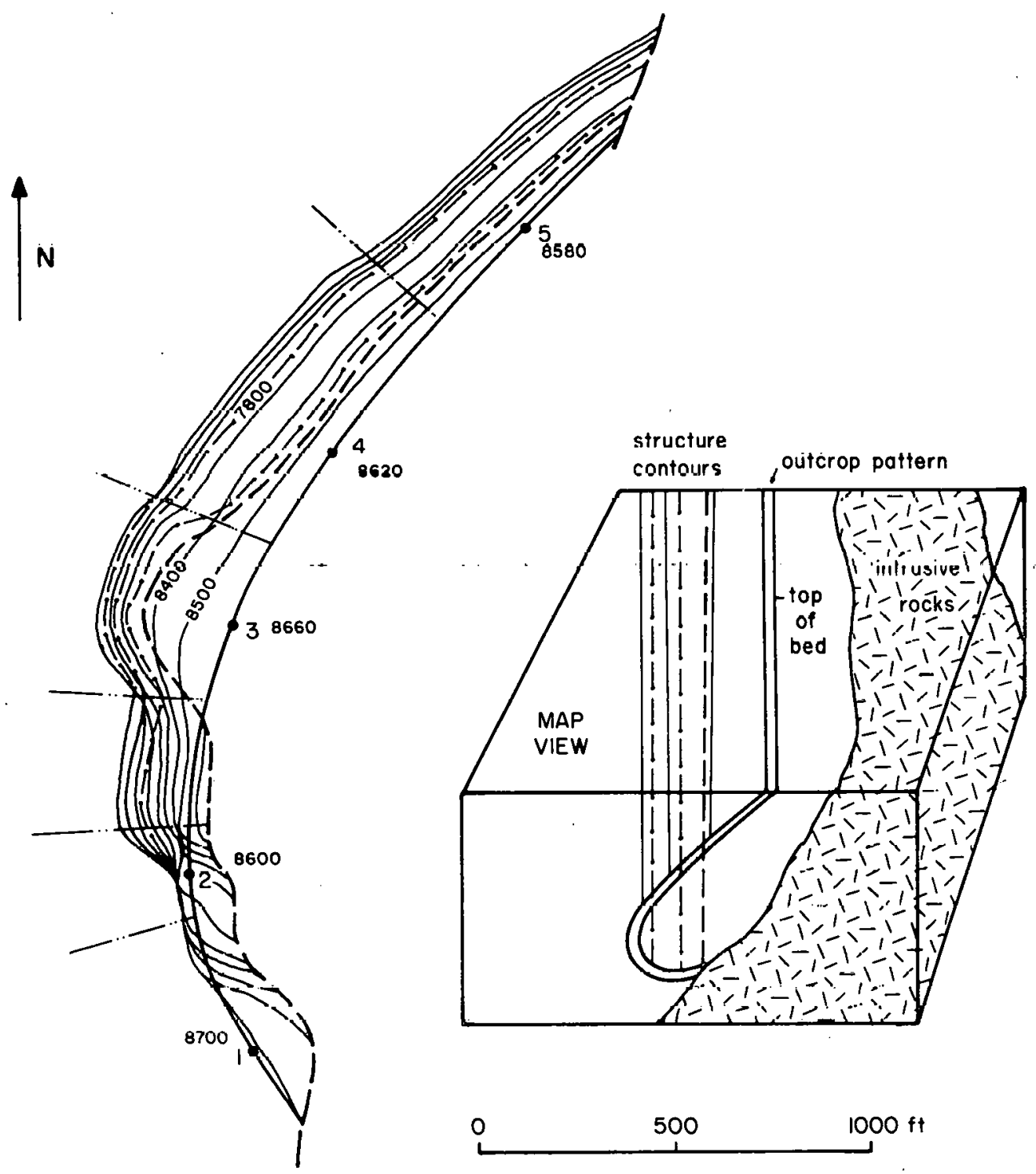

\section{EXPLANATION}

Datum is mean sea level

Contour interval 100 feet

Structure contour on overturned portion of bed (see inset)

- - Structure contour on normal portion of bed (see inset)

Figure B-12. Structure contours on top of mineable Unit 1 , overturned west limb of Onemile Creek Syncline, Onemile Creek area, Medicine Bow Mountains.

- Contact with intrusive rocks

Area segment boundary

- 5 Reference point for area segment with reference elevation

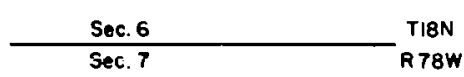




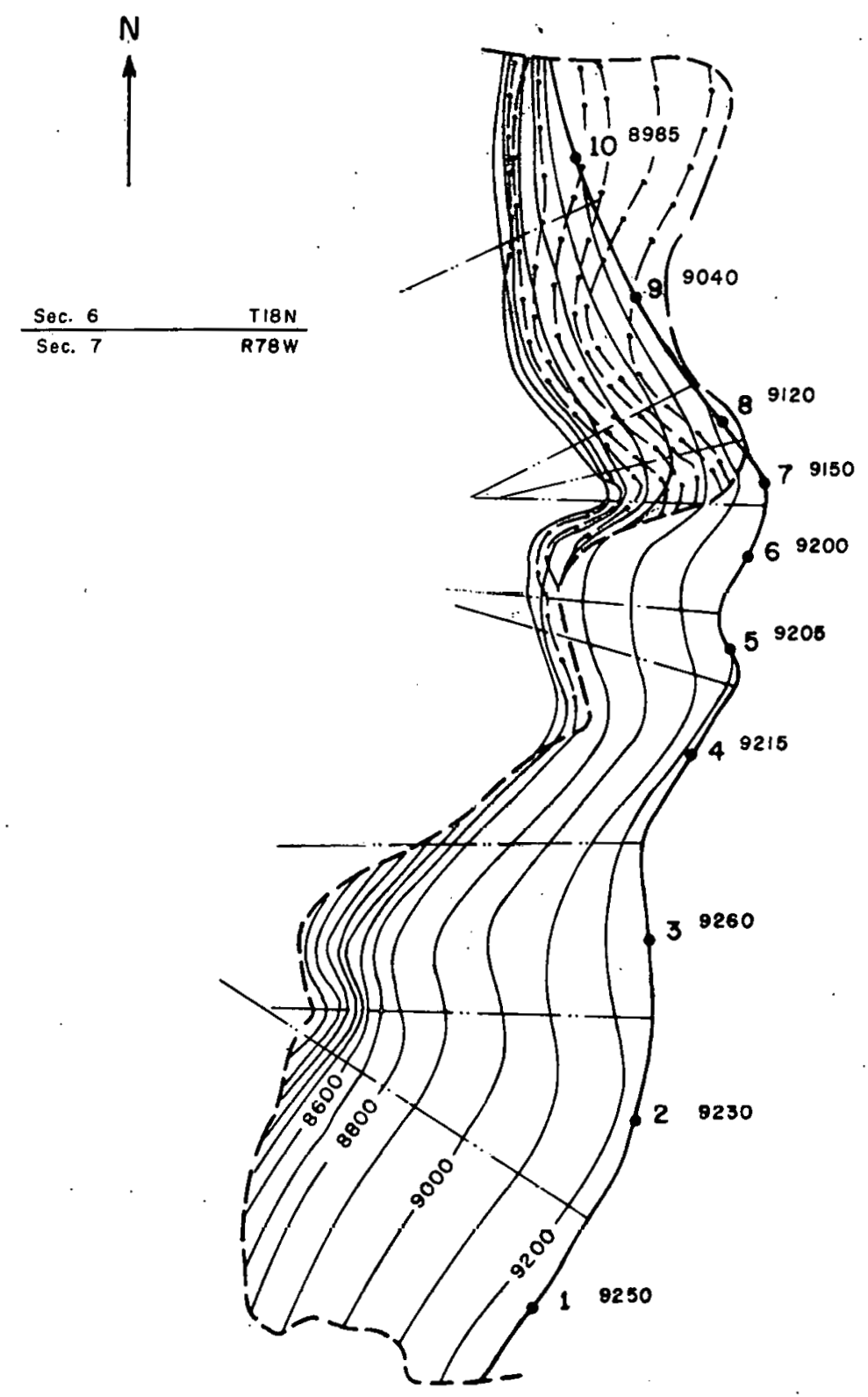

Explanation as on sheet. for Unit 1, overturned west limb

Figure $B-13$.

Structure contours on top of mineoble Unit 1, overturned south ern limb of Onemile Creak syncline, Onemile Creek area, Medicine Bow Mountains. 


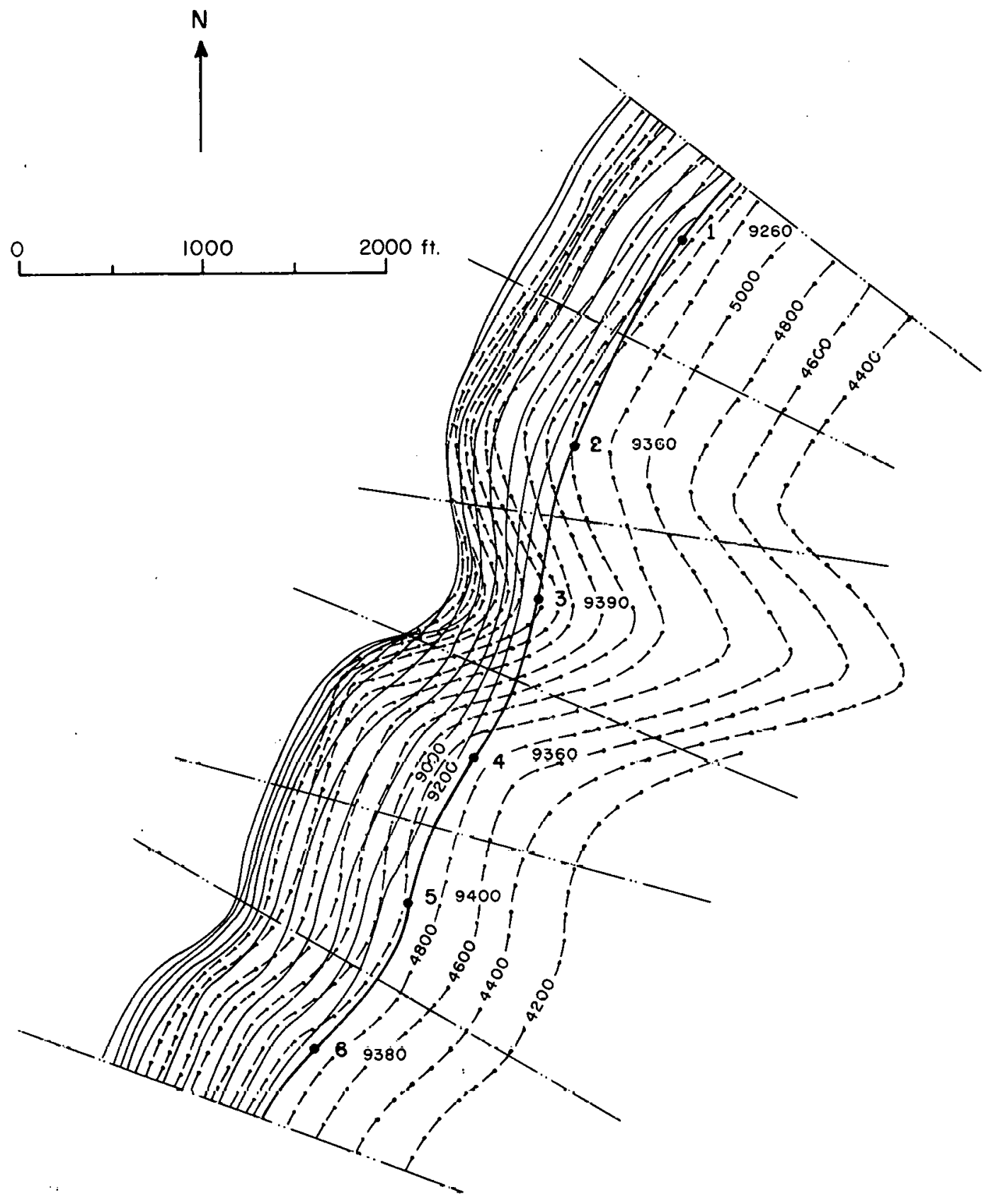

Explanation as on Unit 1, overturned west limb Contour interval 200 feet

Figure $B-14$.

Structure contours on top of principal radioactive unit in Threemile Creek area, Medicine Bow Mountains. 


\section{EXPLANATION FOR STRUCTURE CONTOUR MAPS}

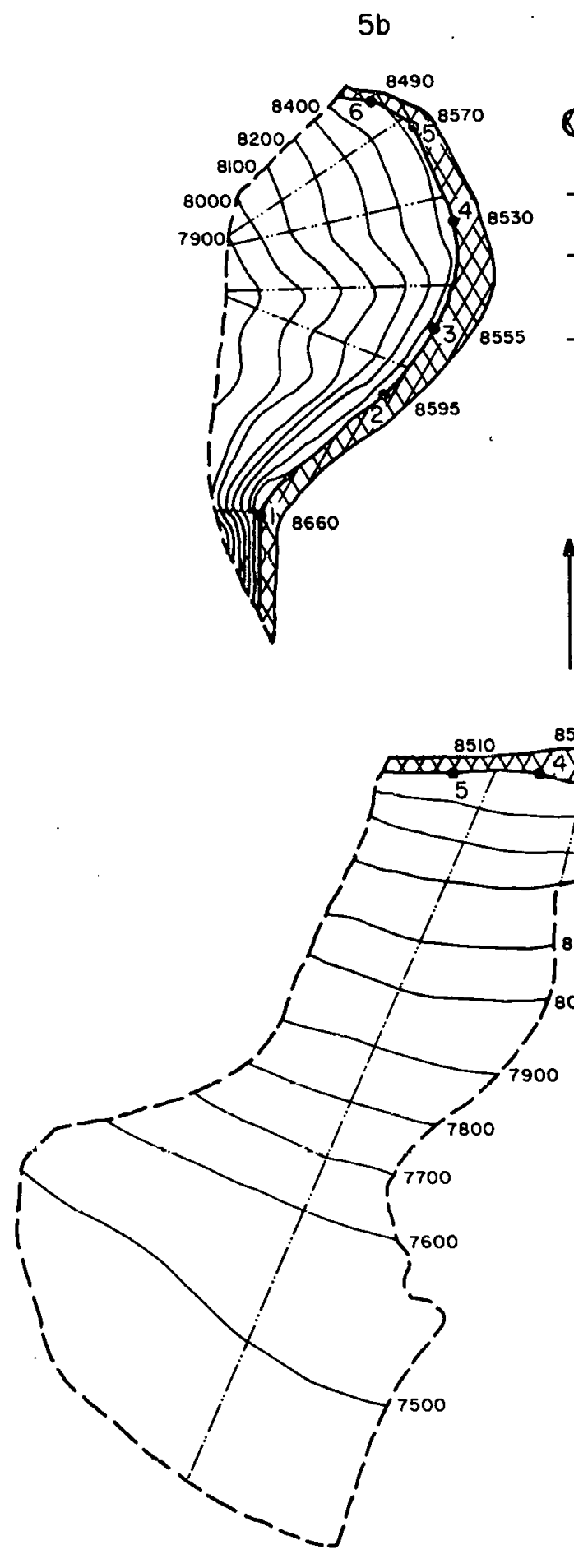

Elevations in feet, datum mean sea level. Contour interval 100 feet.

$\$ \otimes 0$ Outcrop pottern

Structure contour

- Projected contact between unit and intrusive rocks

-... Areo segment boundary

8555 Reference point for area segment with

- 3 reference elevation in feet.
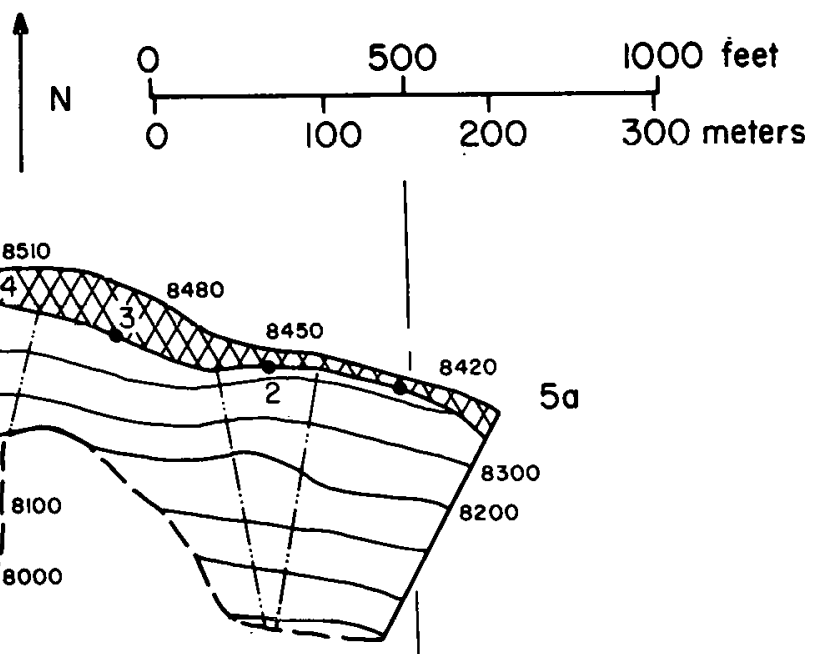

Figure $8-15$.

Structure contours on tops of mineable units $5 a$ and $5 b$, eastern syncline, Onemile Creek area, Medicine Bow Mins. 


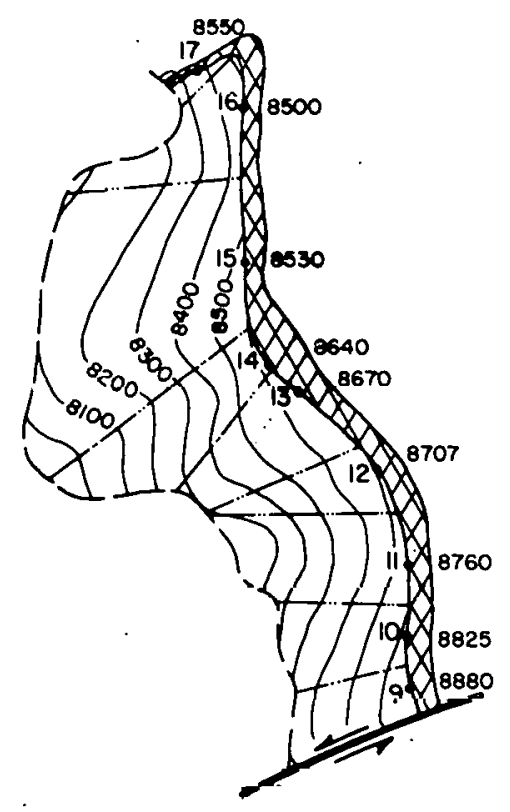

Figure $B-16$

Structure contours on top of mineable unit

$5 \mathrm{~b}$, east limb of Onemile Creek

Syncline, Onemile Creek area.

Explanation as on sheet for eastern

syncline.
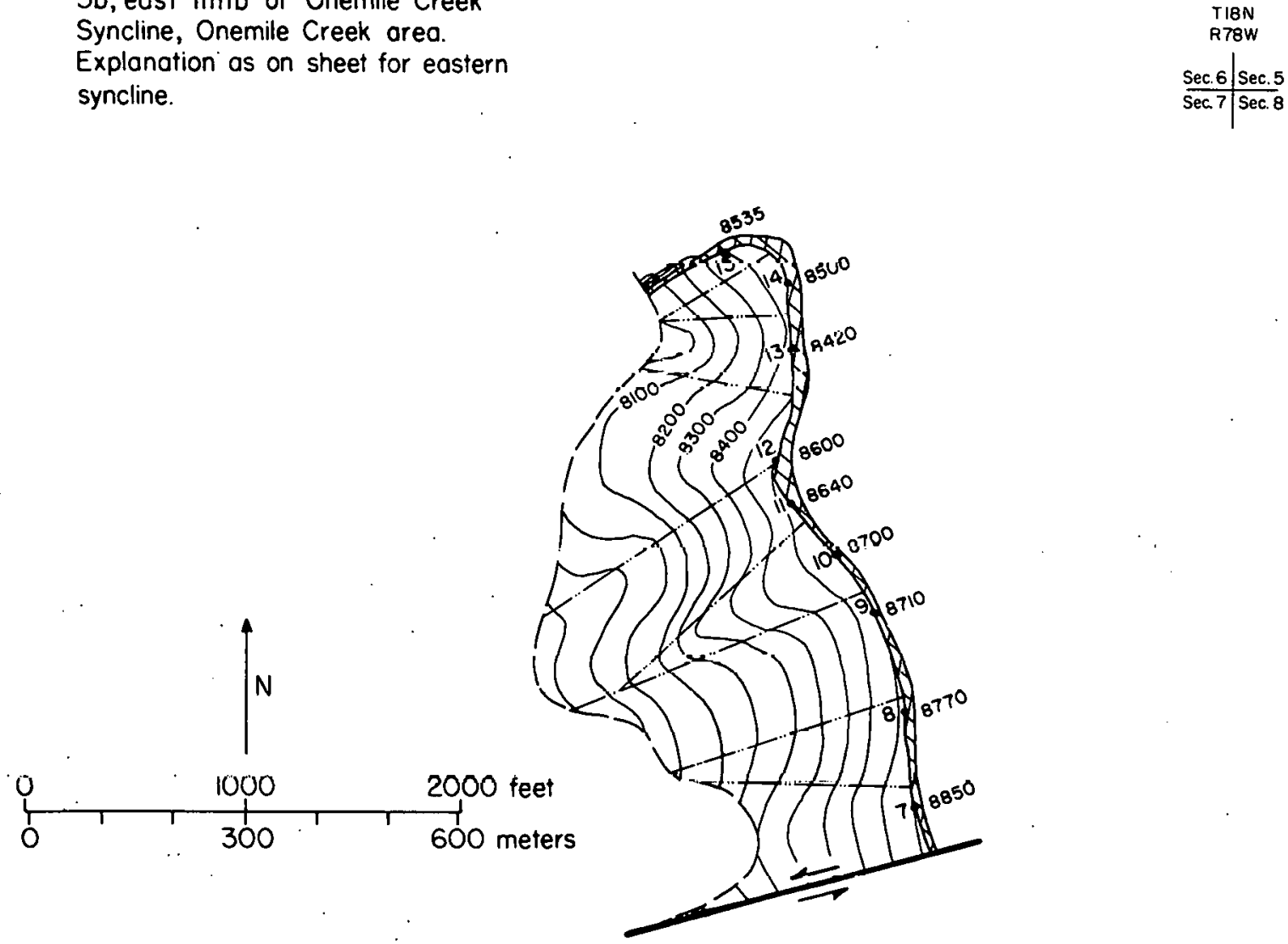

Structure contours on top of mineable unit $5 a$, east limb of Onemile Creek

Syncline, Onemile Creek area.

Explanation as on sheet for eastern syncline.

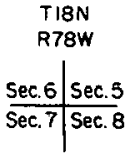




\section{Appendix C}

Graphical Presentation of Placement and True Thickness of Ore Beds in the Outcrop Transects and the Drill Holes.

Sierra Madre Unit \#3

Figure

C-1 Transect \#1, \#2, \#3

C-2 Transect \#4, \#5, \#6, \#7.

C-3 Transect \#8, \#9, \#10, \#11

c- 4

Transect \#12, \#13, \#14

C-5 Transect \#15, \#16,\#17............... 132

C.-6 Transert \#18, \#19, \#20...........,...,... 133

C-7 Transect \#21A, \#21B,\#22A . . . . . . . . . . . . . . 134

C-8 Transect \#22B, \#23,\#24 ............... 135

C-9 Core SM-1, SM-2, JP-1 . . . . . . . . . . . . 136

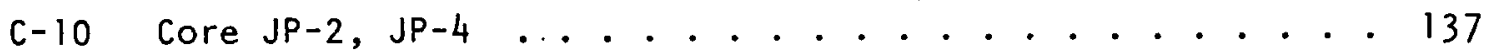

Medicine Bows

C-11 Transects \#TIA, \#TIB, \#TIC............. 138

C-12 Transects \#T2 .................... 139

C-13 Transects \#T3, \#T4.................. 140

C-14 Transect \#T5....................... 141

C-15 Transect \#T6.................... 142

C-16 Transect \#T7................... . . 143

C-17 Transect \#T8................... . 144

C-18 Core, EMB-1 ........................... 145

C-19 Core, EMB-6 . . . . . . . . . . . . . . . . . 146

C-20 Core, EMB-7 . . . . . . . . . . . . . . . . . . 147

C-21 Core, EMB-8 .. . . . . . . . . . . . . . . 148

C-22 Core, EMB-9, EMB-10................ 149

C-23 Core, $\mathrm{MB}-16$. . . . . . . . . . . . . . . . . 150

C-24 Core, EMB-II......................... 151 


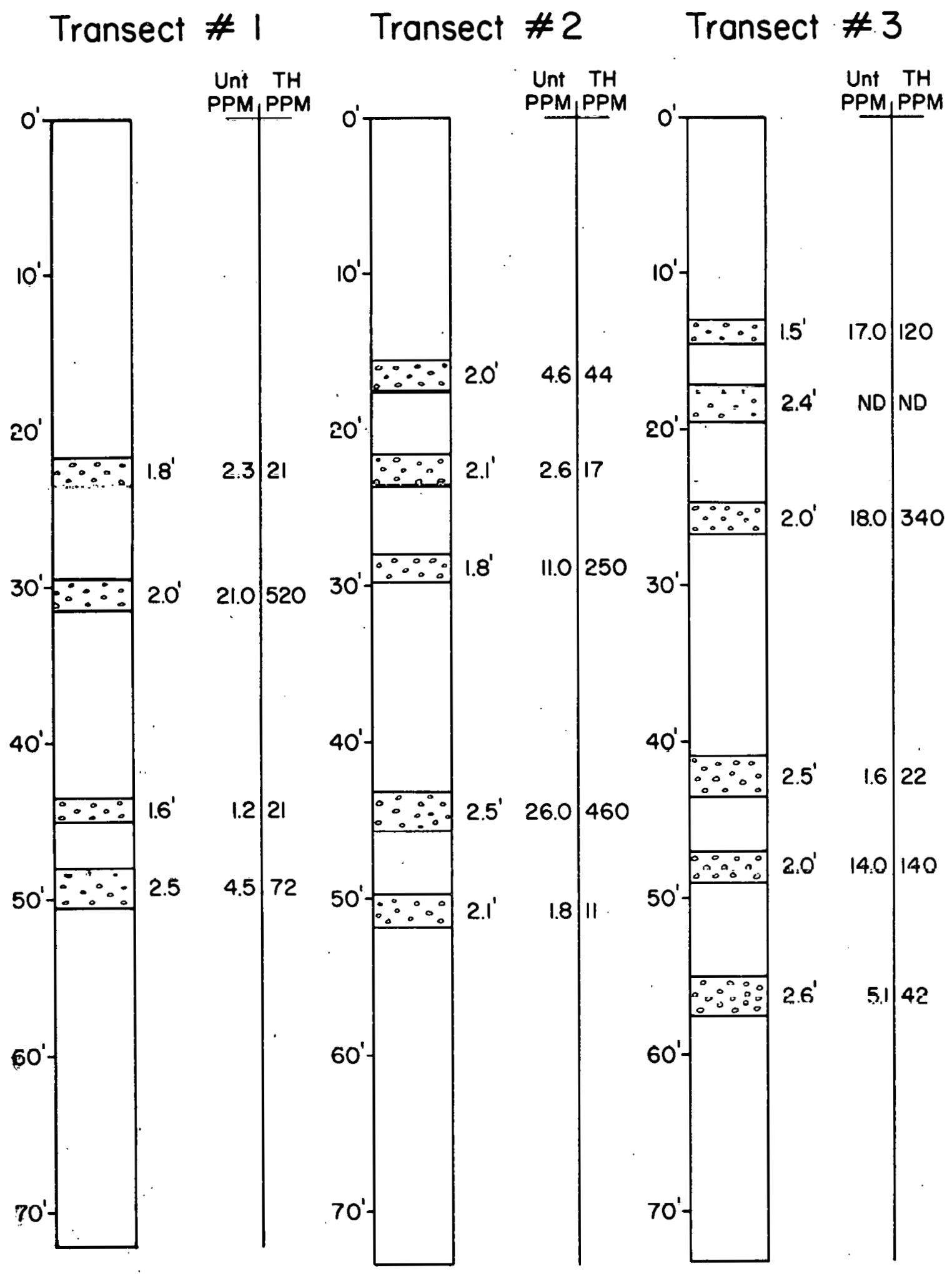

' Figure $\mathrm{C}-\mathrm{i}$. Thickness and $\mathrm{U}$,Th values of Unit 3, Deep Gulch Conglomerate from transects 1, 2 and 3, Carrico Ranch, northwest Sierra Madre. $\quad$ NO = NO DATA AVAILABLE 


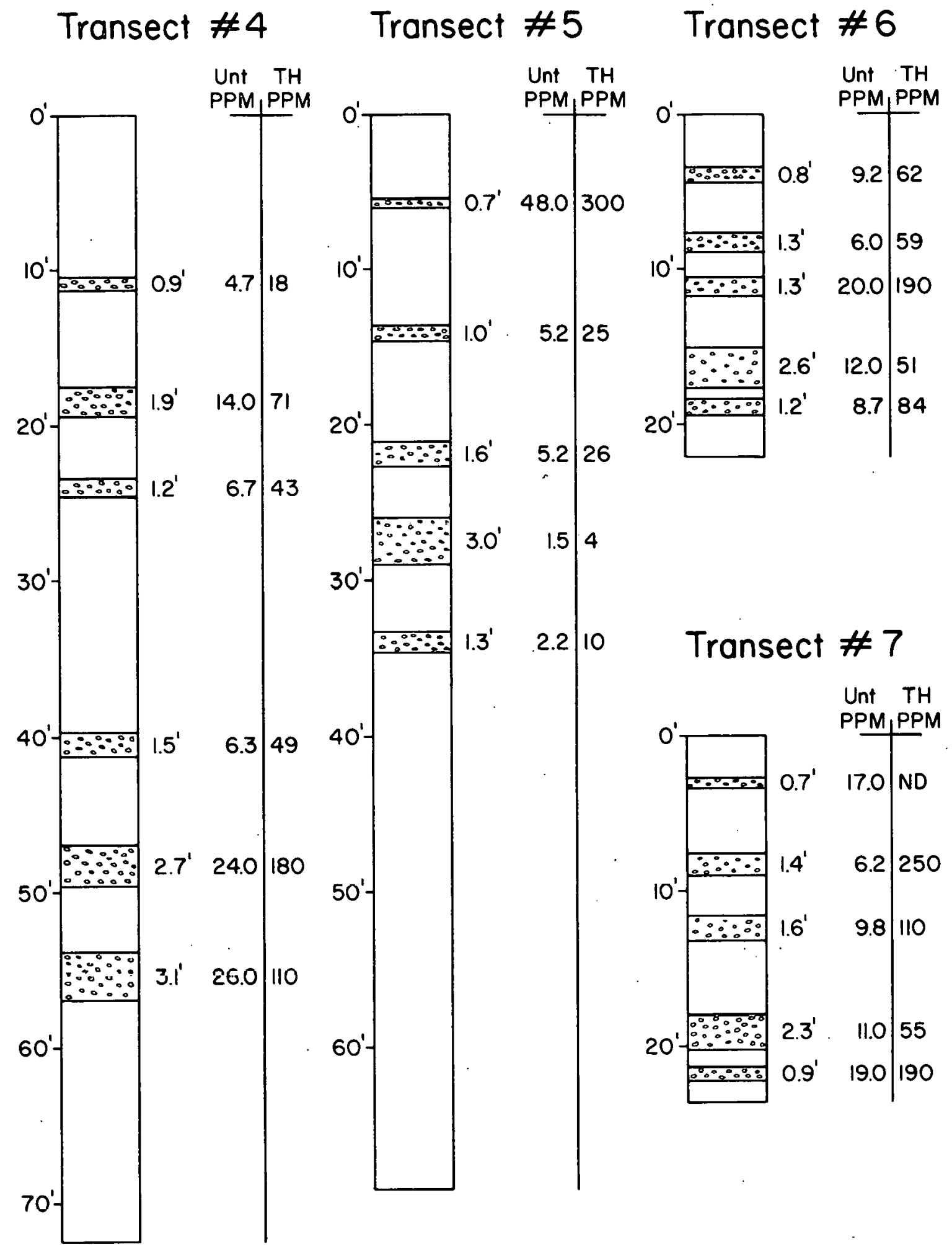

Figure C-2. Thickness and U,Th values of Unit 3, Deep Fulch Conglomerate from transects. 4, 5, 6 and 7, Carrico Ranch, northwest. Sierra Madre. $\quad N D=$ NO DATA AVAILARLE 


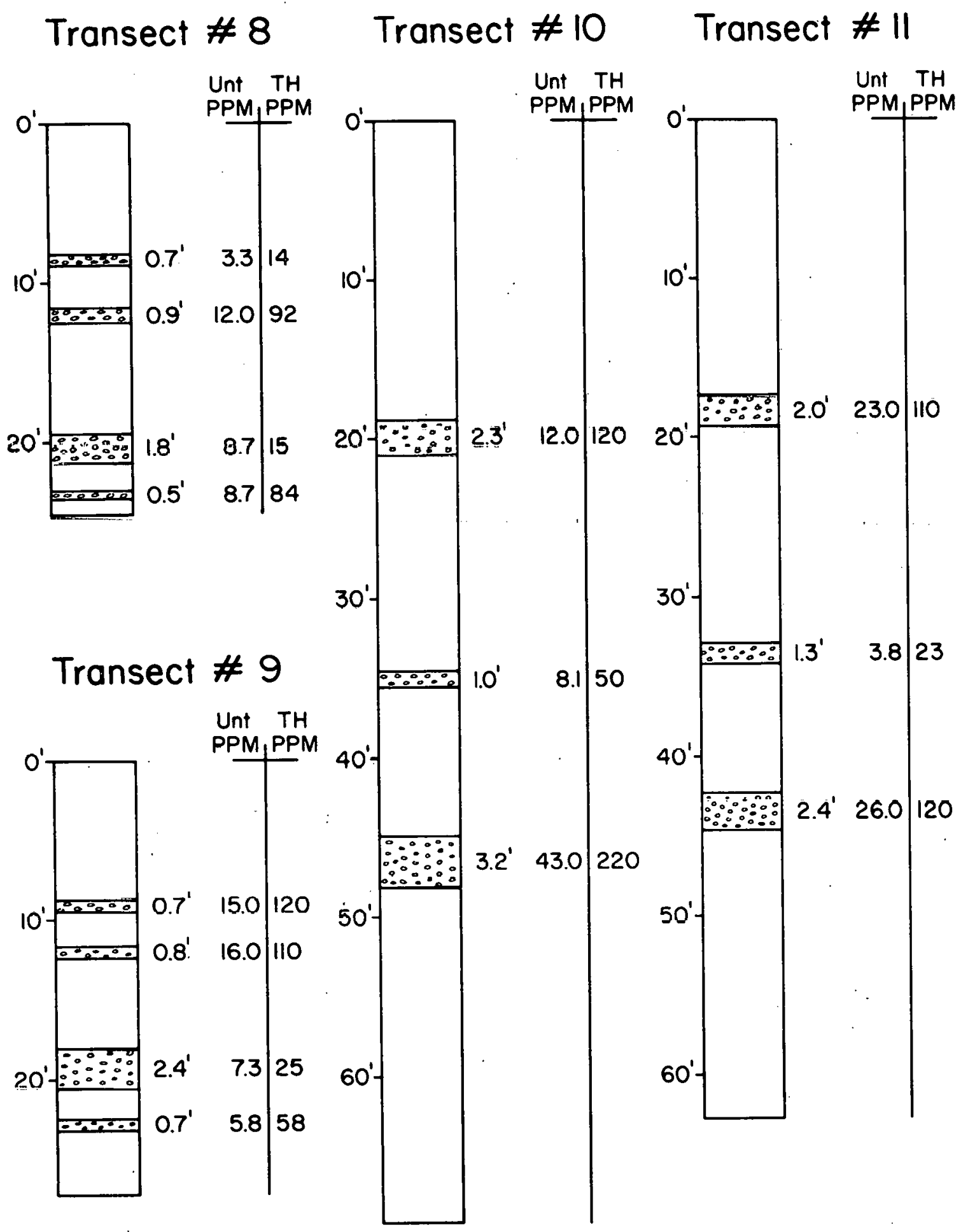

Figure $\mathrm{C}-3$. Trickness and $U$,Th values of Unit 3, Deep Gulch Conglomerate from transects 8, 9, 10 and 11, Carrico Ranch, northwest Sierra Madre. 


\section{Transect \#12 Transect\#13 Transect\#14}

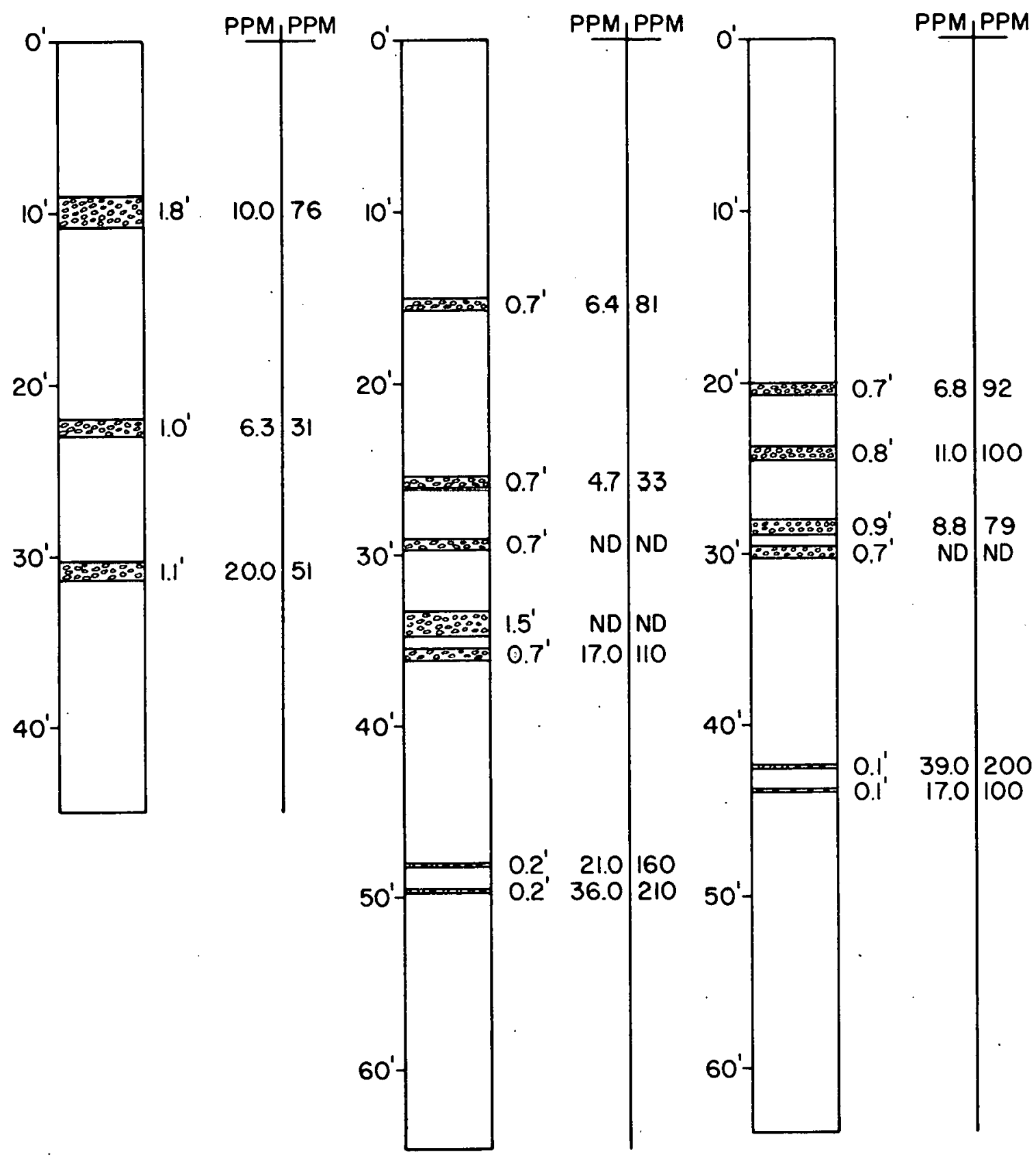

Figure C-4. Thickness and U,Th values of Unit 3, Deep Gulch Conglomerate from transects 12,13 and 14, Carrico Ranch and Deep fiulch, northwest Sierra Madre. ND = NO DATA AVAILABLE 


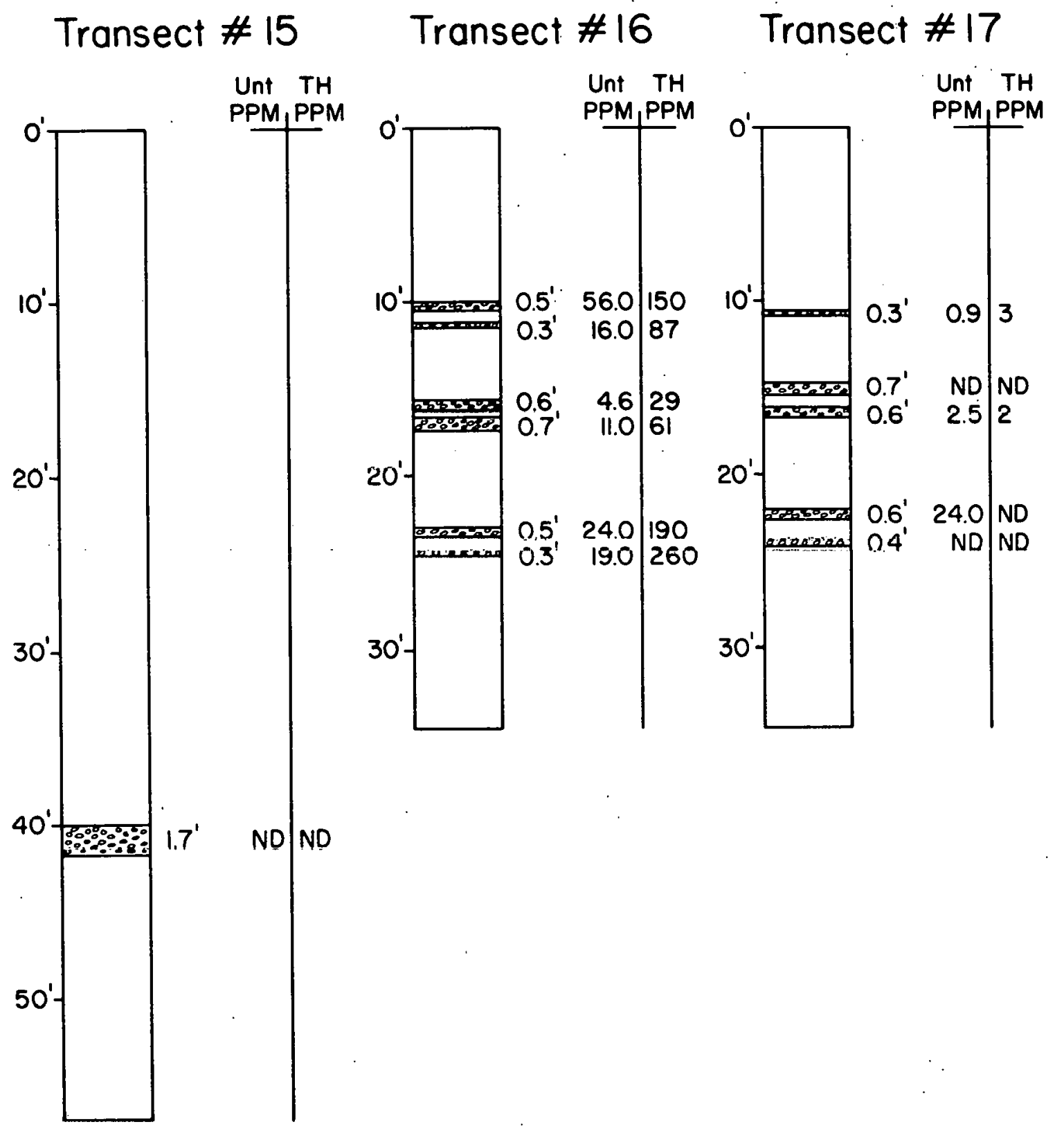

Figure C-5. Thickness and $U, T h$ values of Unit 3, Deep Gulch Conglomerate from transects 15, 16 and 17, Deep Gulch, ND $=$ NO DATA AVAILABLE northwest Sierra Madre. 


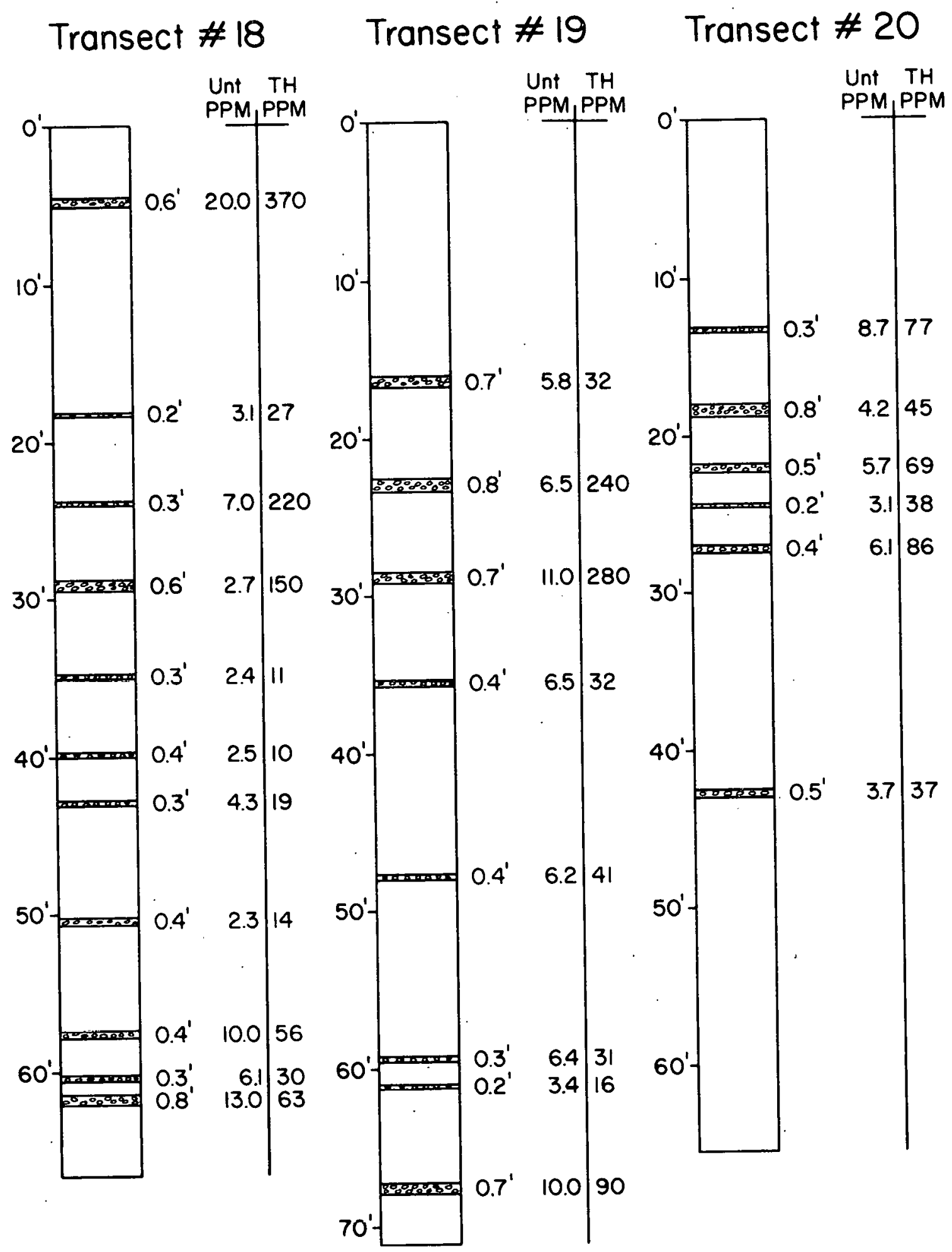

Figure $c-6$. Thickness and $U, T h$ values of Unit 3 , Deep Gulch Conglomerate from transects 18, 19, 20, Manning Ranch, northwest Sierra Madre. 


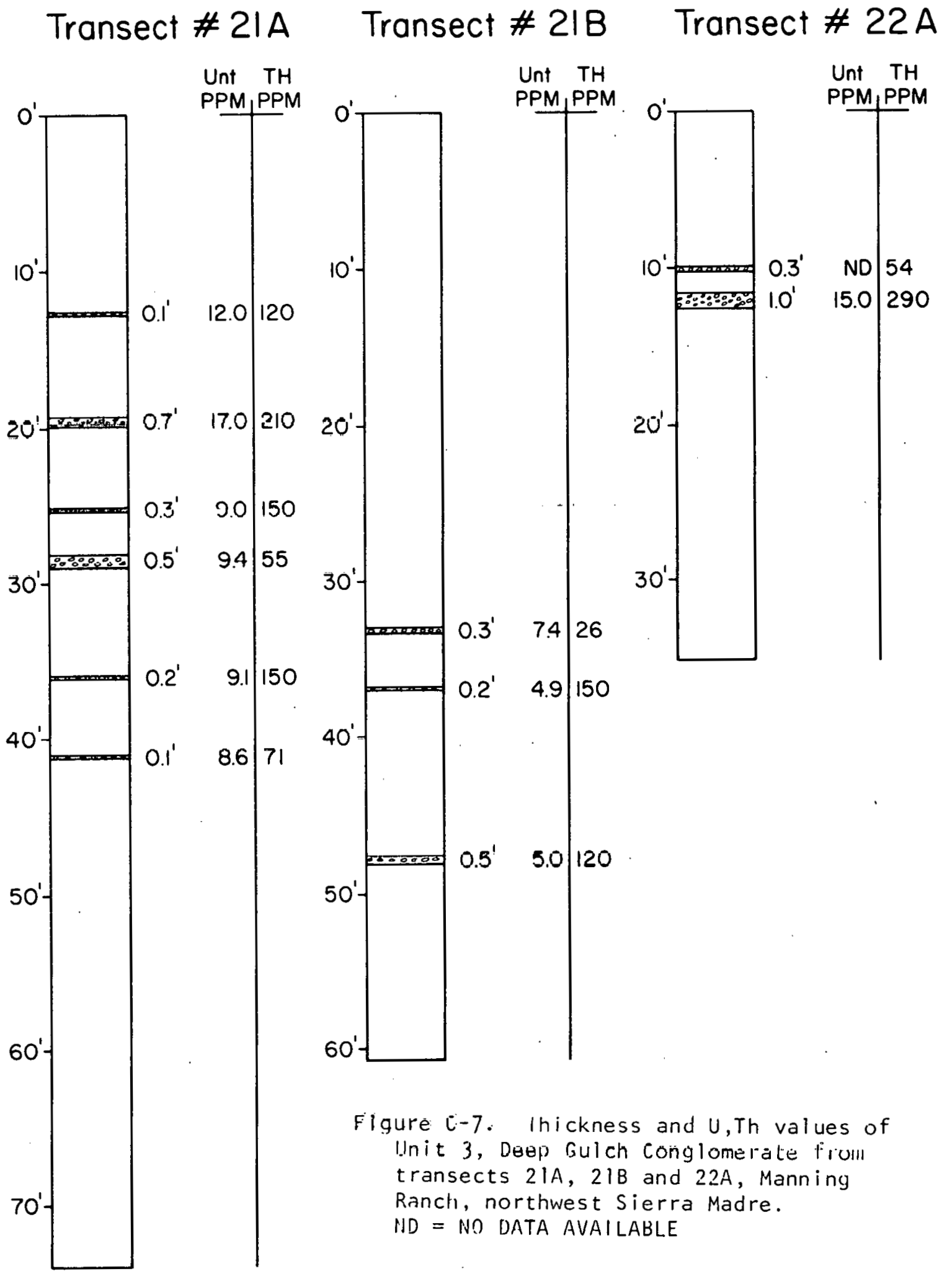




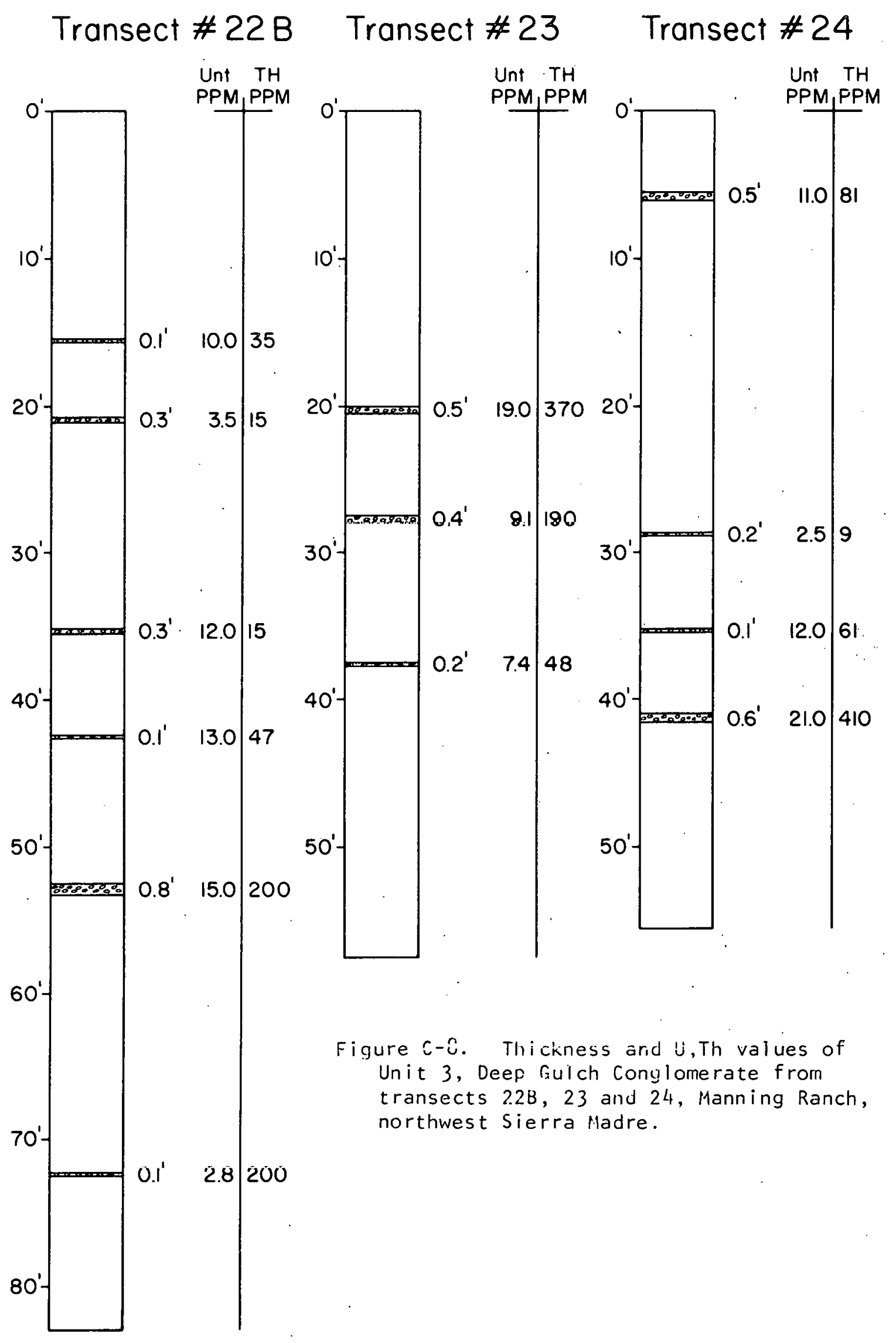


SM-I Core

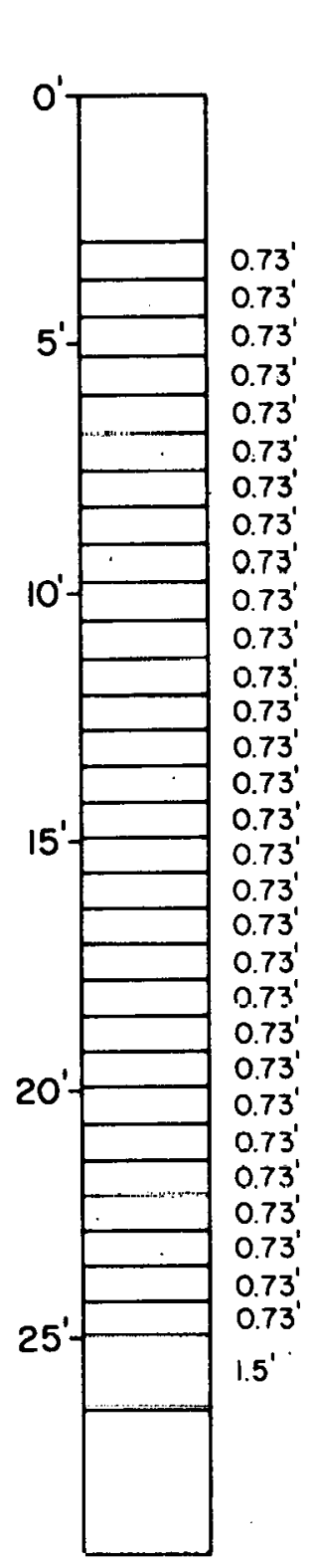

SM-2 Core

Unit TH

PPM PPM

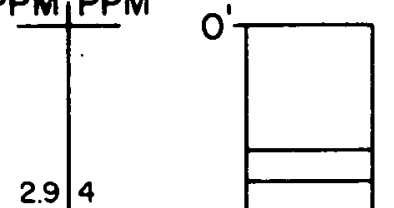

6.29

6.125

5.212

8.632

3.5 .

1.68

3.87

3.53

6.110

6.822

8.422

5.413

14.0. 31

30.066

15.031

4.66

4.410

4.78

3.615

2.04

3.513

25.097

18.053

16.035

\begin{tabular}{r|r|r|}
11.0 & 29 \\
370 & 79
\end{tabular}

92.0300

6.933

3.48

2.910

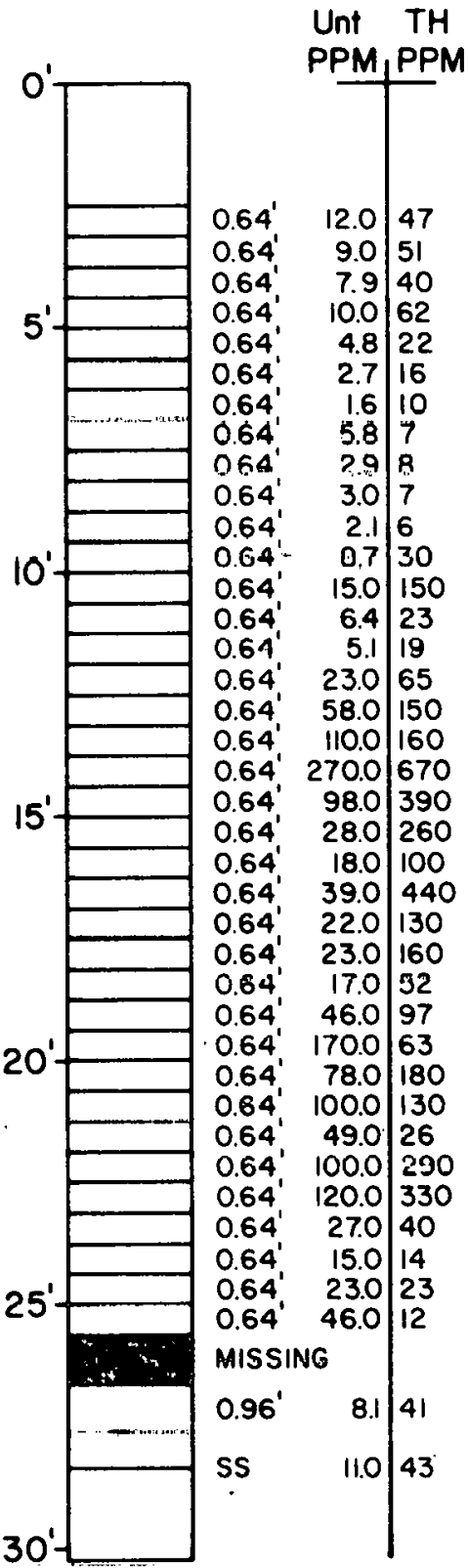

$30^{\prime}$
JP-I Core

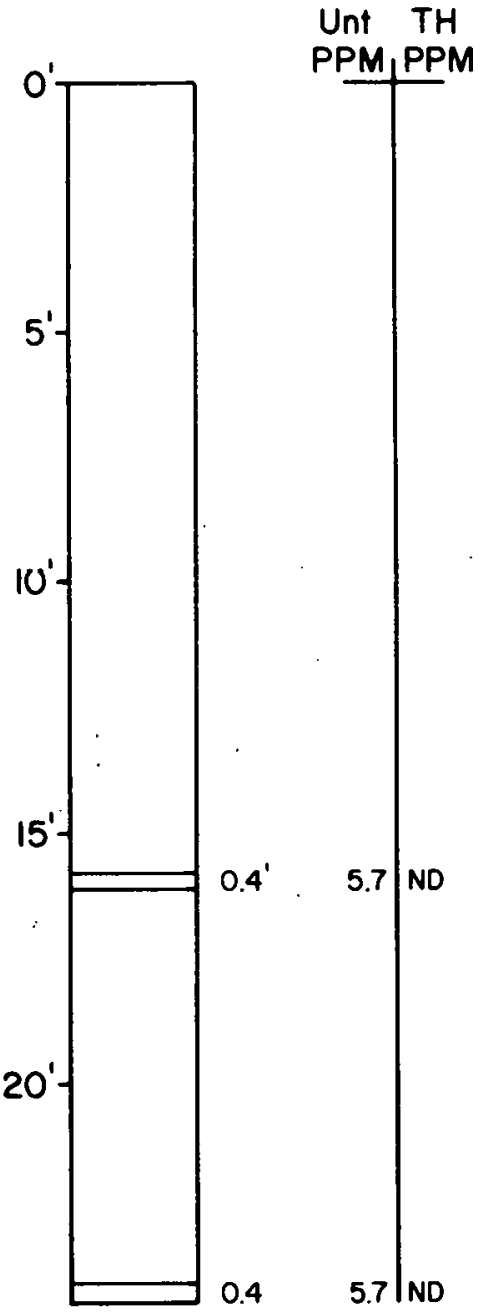

Sierra Madre Unit \# 3

$N D=N O$ DATA AVAILABLE SS = SPOT SAMPLE

Figure $\mathrm{C}-9$ 


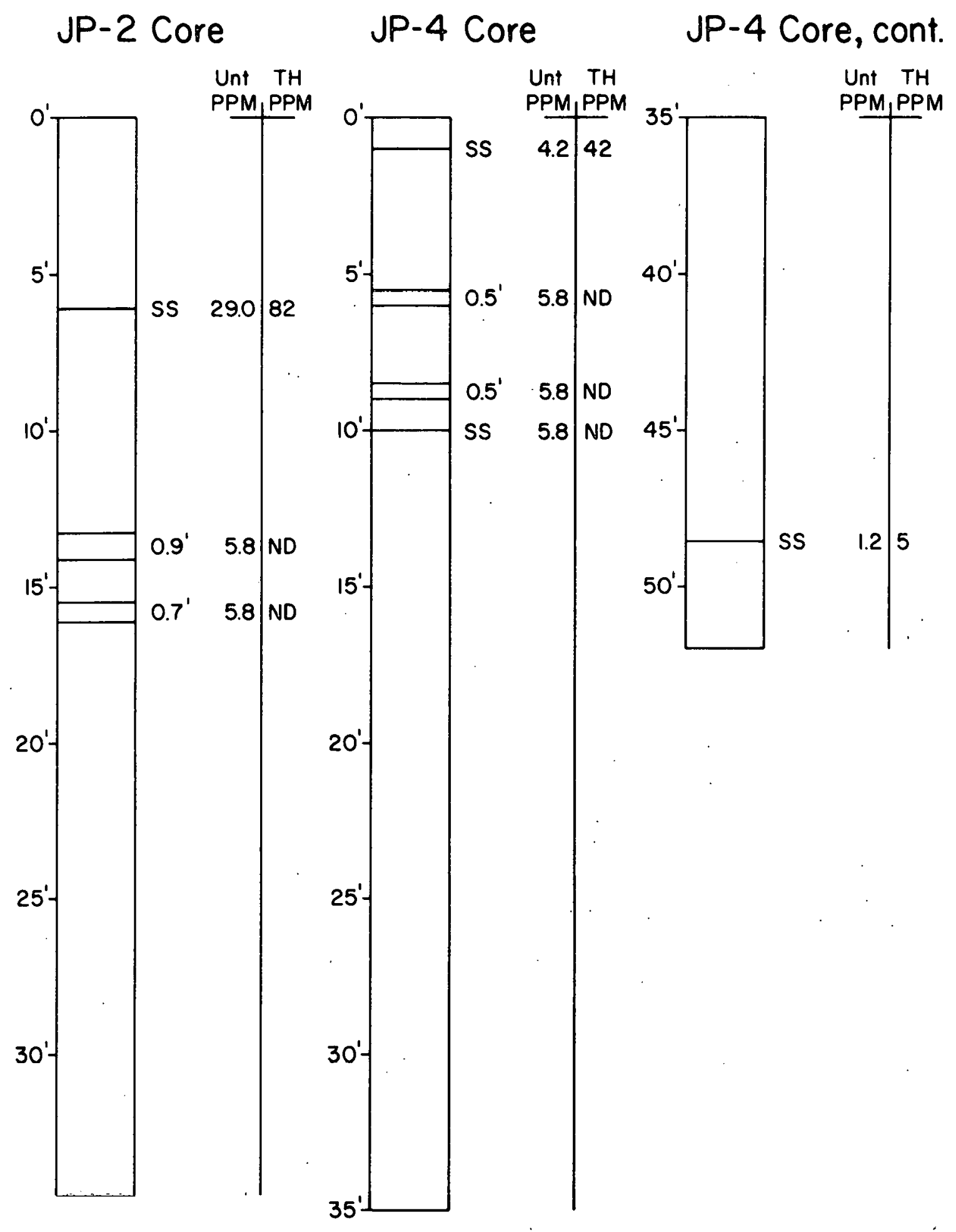

Sierra Madre Unit \# 3

ND = NO DATA AVAILABLE

Figure $c-10$ SS = SPOT SAMPLE 


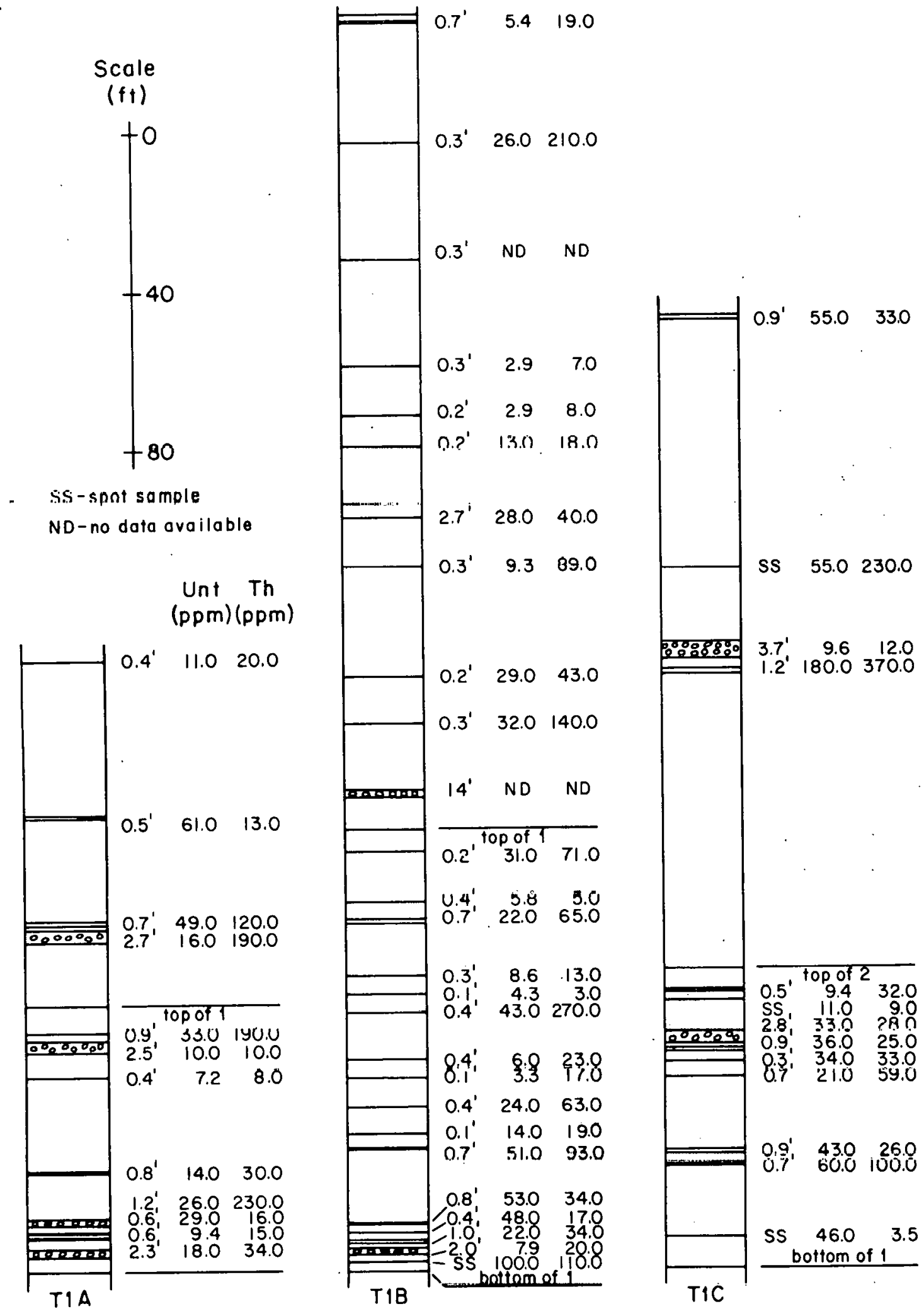

Figure $C-l l$. Thickness and $U, T h$ values of radiooctive conglomerates from surface transects, $T 1 A, T 1 B$, and T $1 C$, Onemile Creek area, Medicine Bow Mins. 


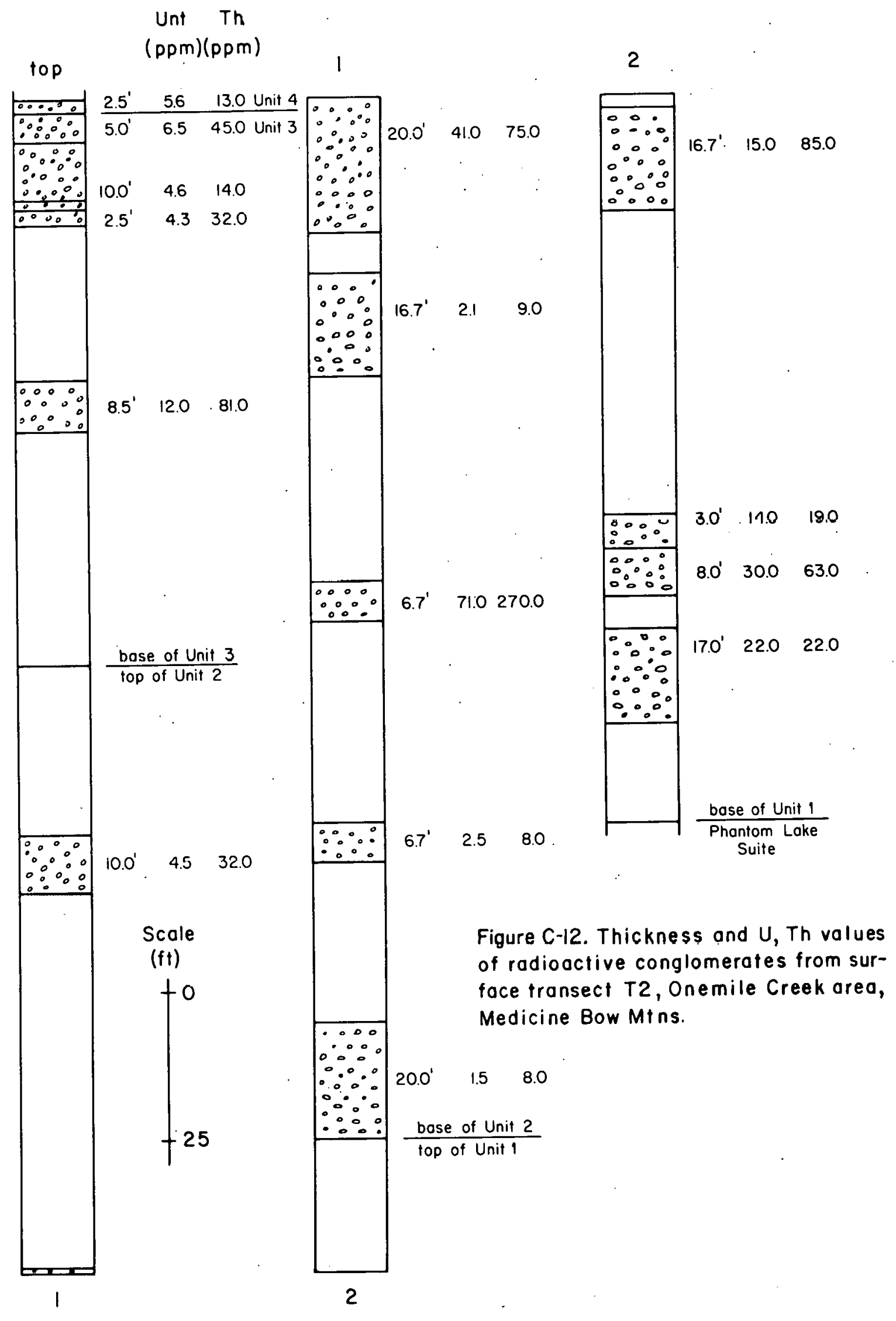



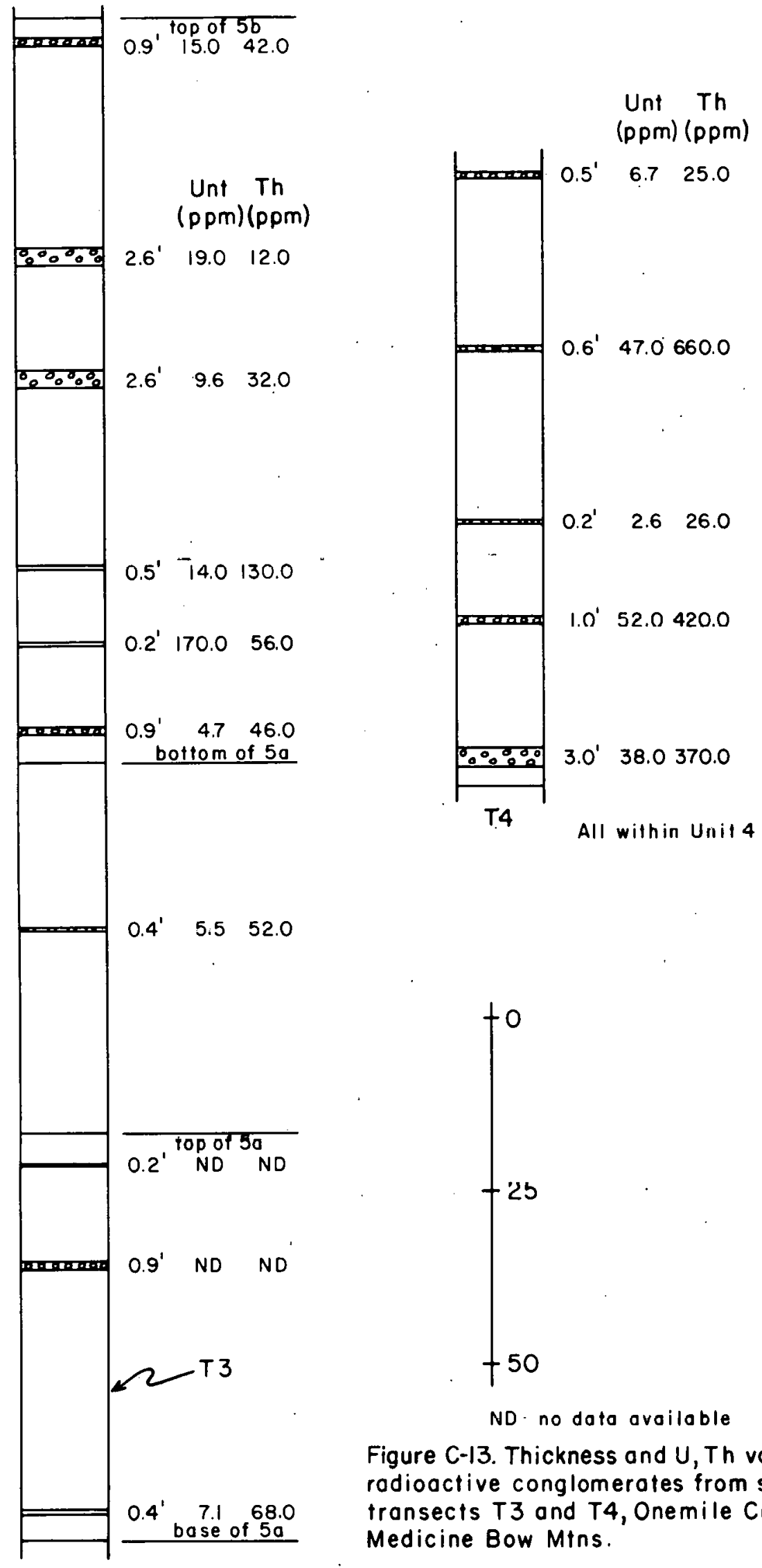

ND - no data available

Figure $C-13$. Thickness and $U, T h$ values of radioactive conglomerates from surface transects T3 and T4, Onemile Creek area, Medicine Bow Mins. 

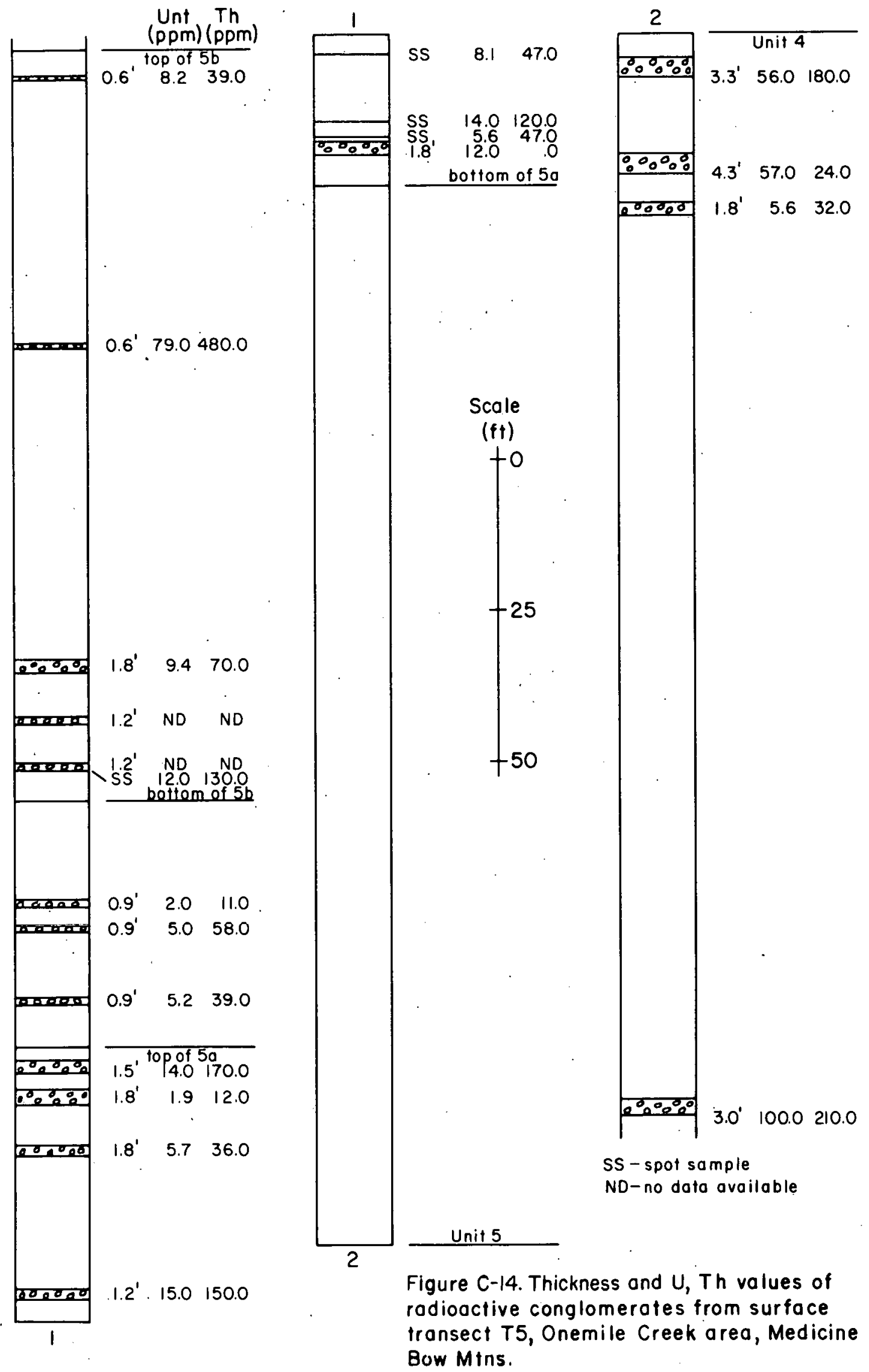

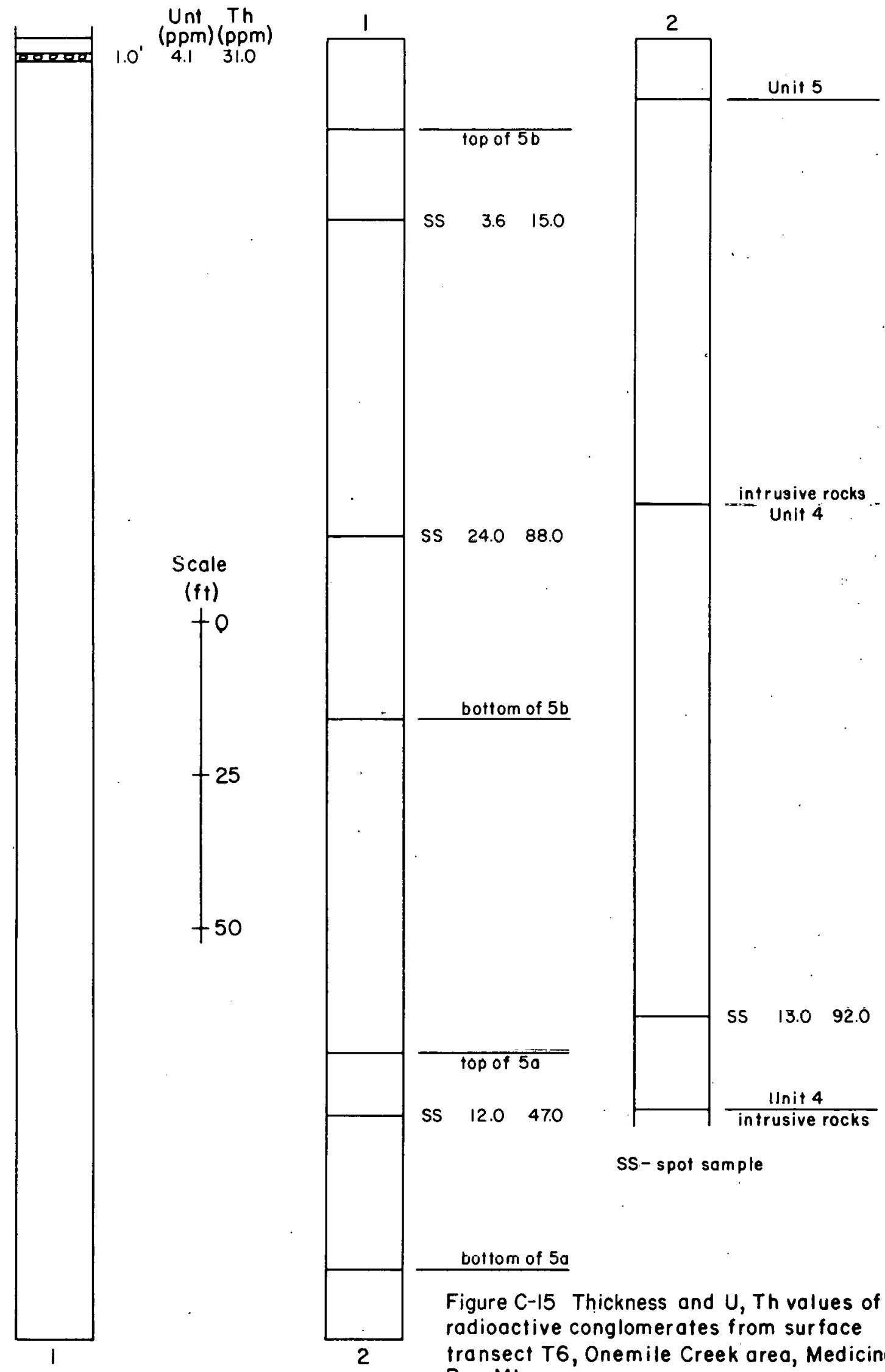

SS $\quad 12.0 \quad 47.0$

SS- spot sample

bottom of $5 a$

Figure $\mathrm{C}-15$ Thickness and $U, T$ Th values of radioactive conglomerates from surfoce transect T6, Onemile Creek area, Medicine Bow Mins. 


\section{Unt Th \\ (ppm)(ppm)}

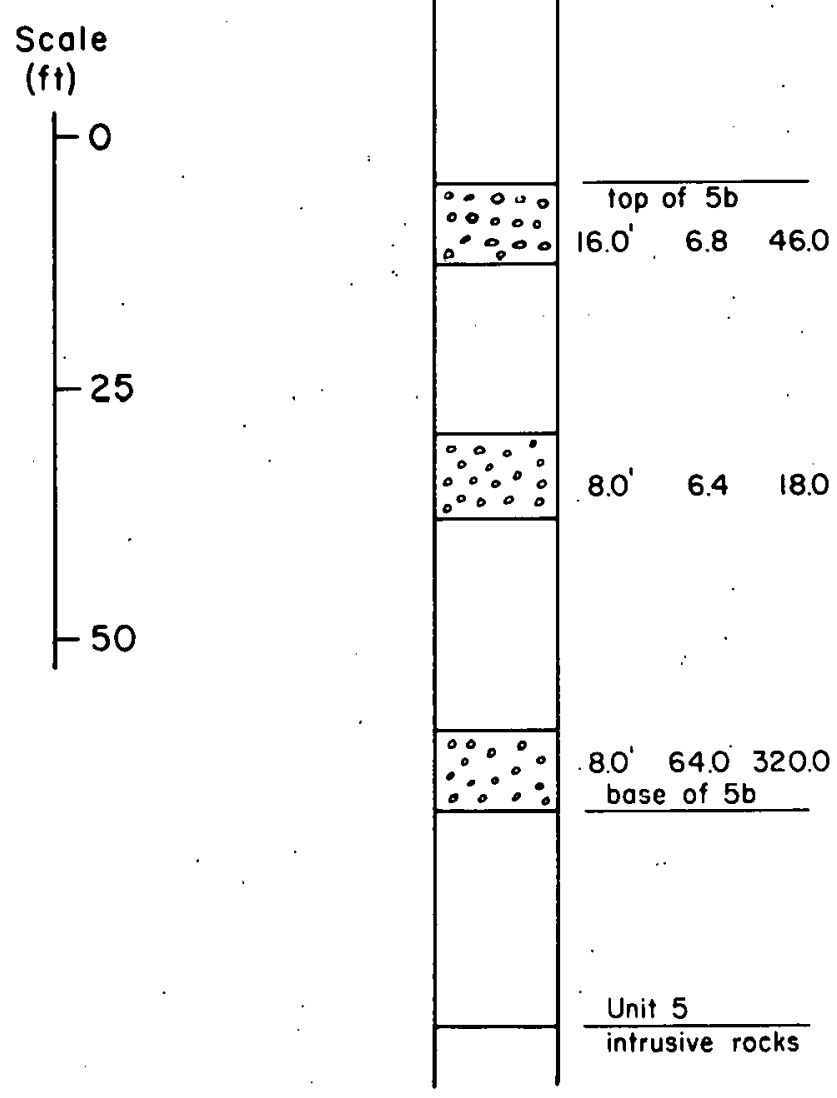

Figure $C-16$. Thickness and $U, T h$ values of radioactive conglomerates from surface transect T7, Onemile Creek areo, Medicine Bow Mins. 

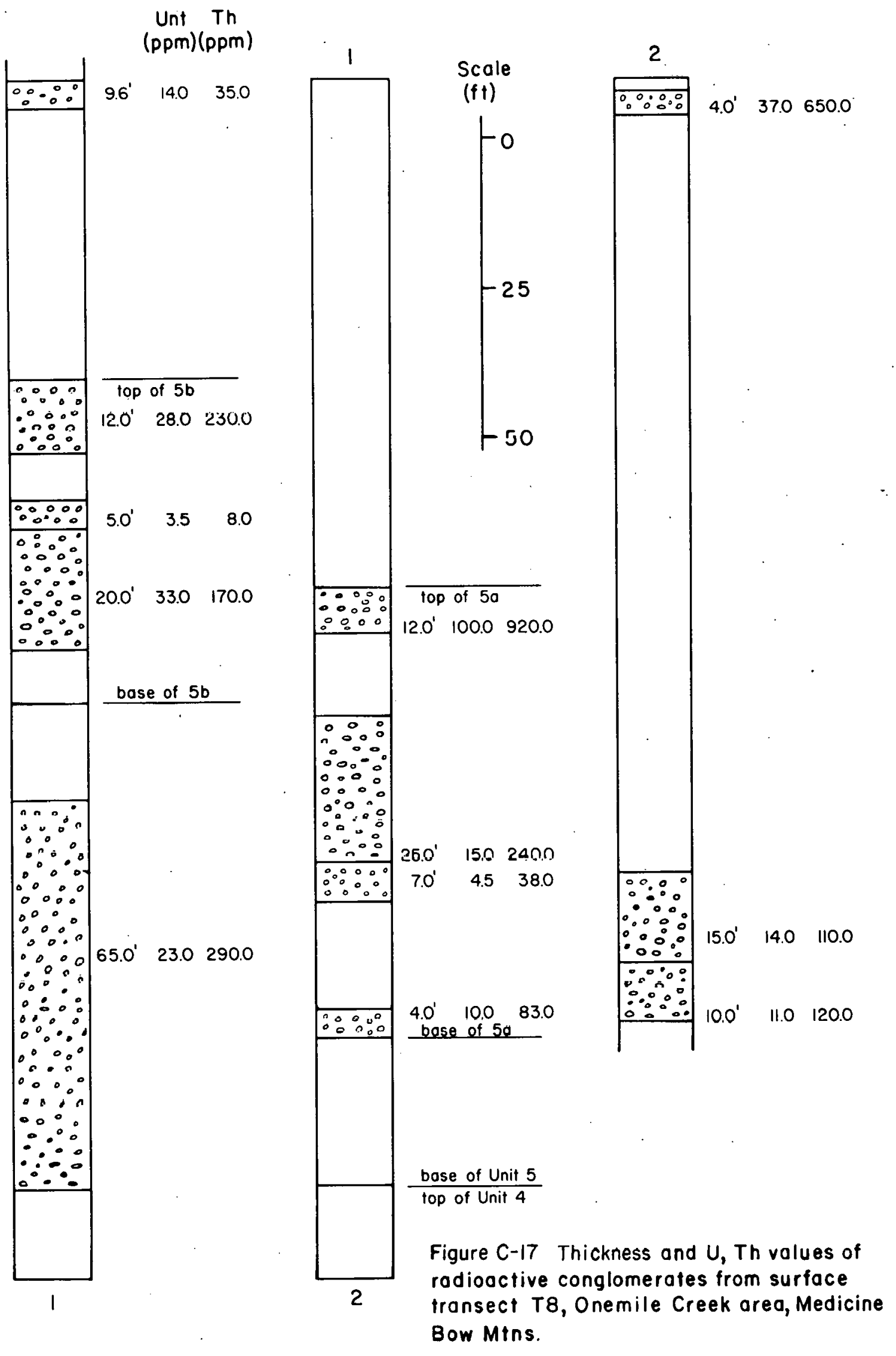


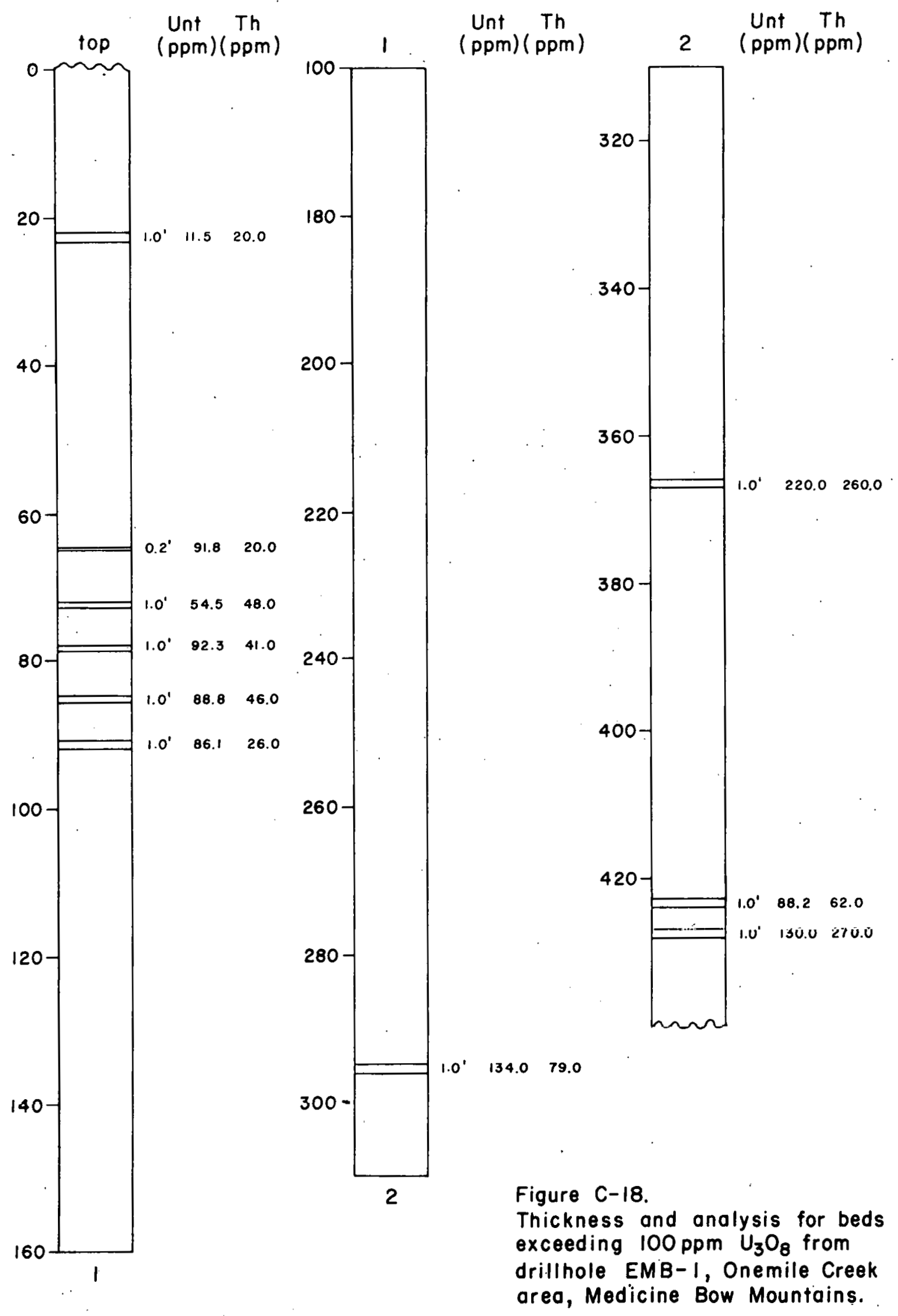




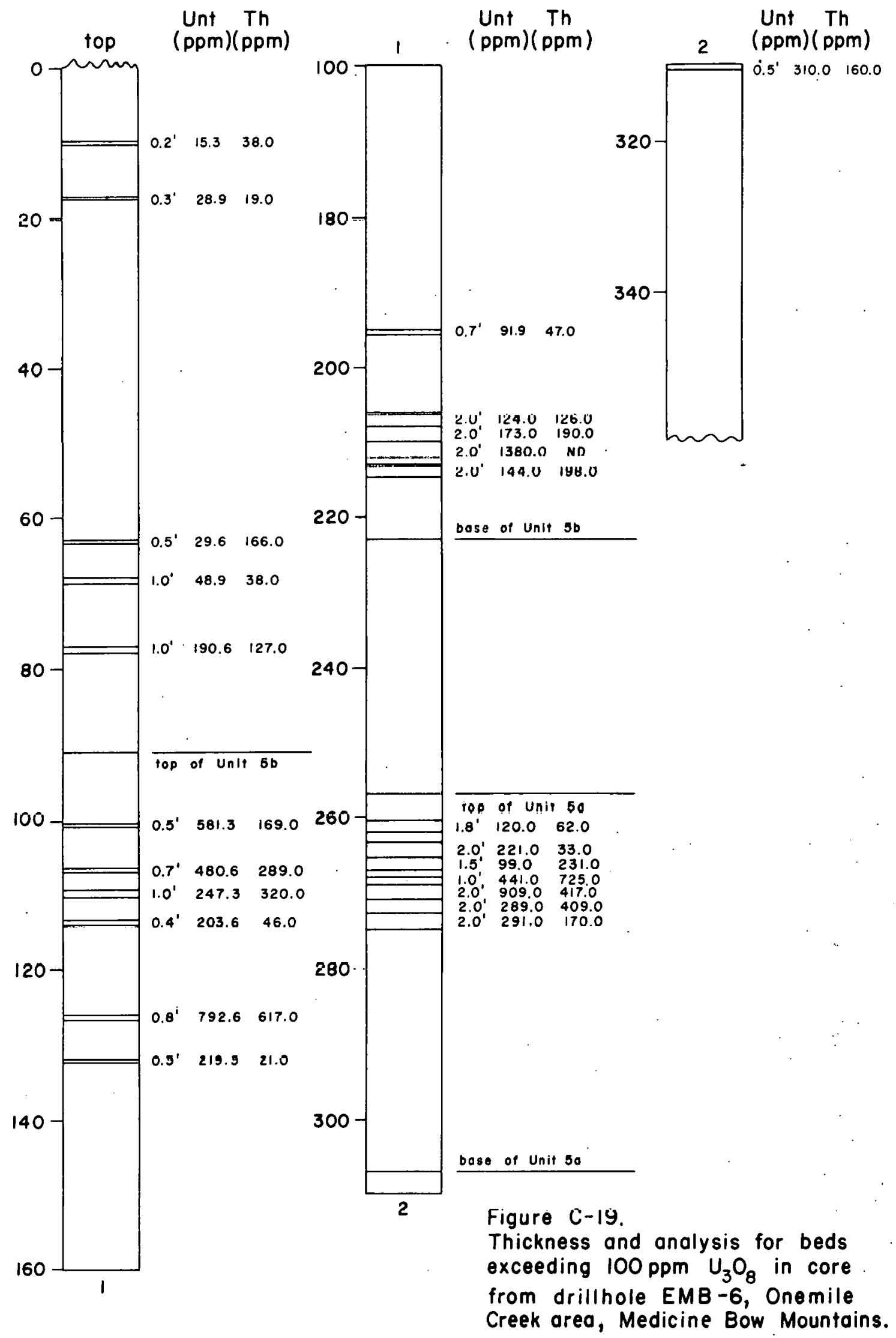




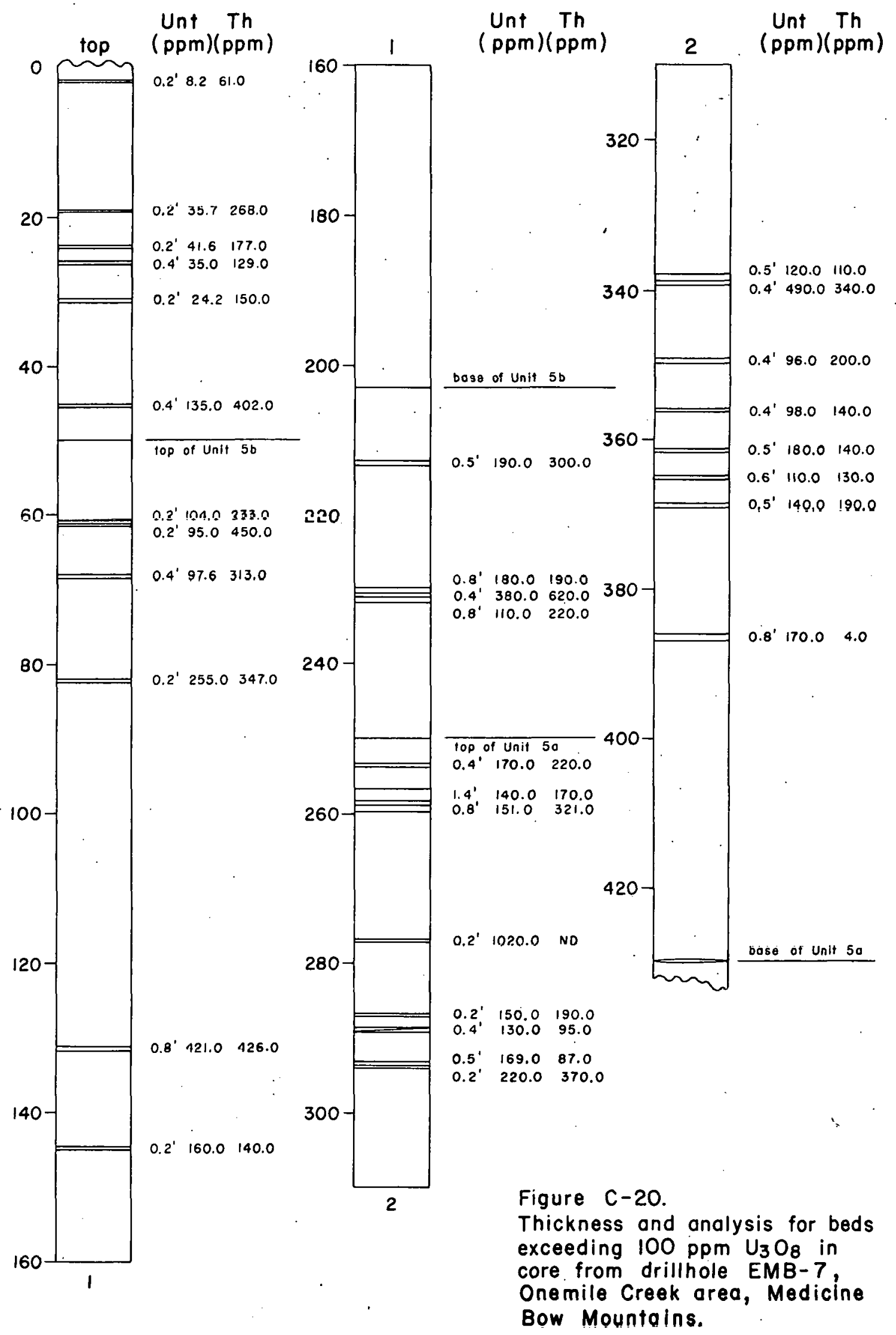


$\underset{(p p m)(p p m)}{\text { Unt Th }}$

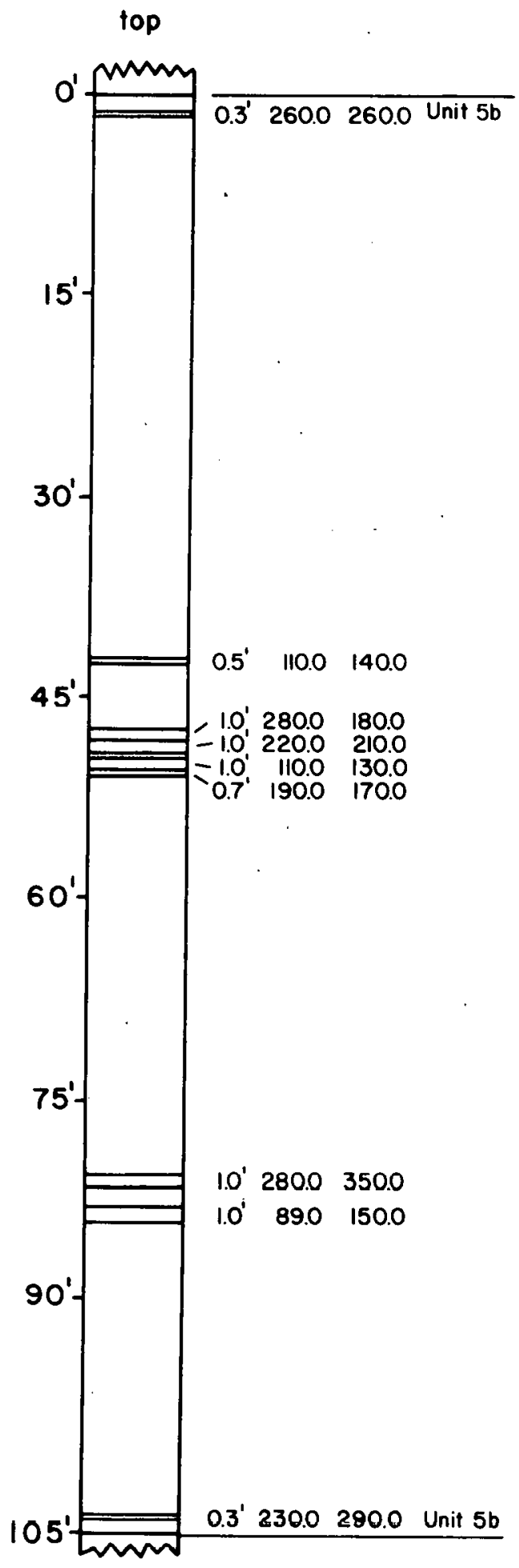

Figure $\mathrm{C}-21$.

Thickness and analysis for beds exceeding $100 \mathrm{ppm} \mathrm{U}_{3} \mathrm{O}_{8}$ in core from drill hole $E M B-8$, Onemile Creek area, Medicine Bow Mins. 
Unt Th

(ppm) (ppm)

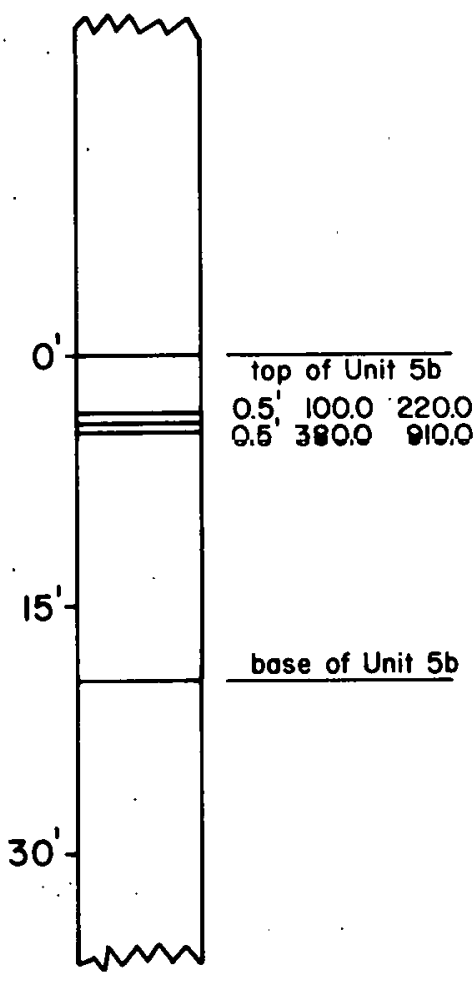

Unt Th

(ppm)(ppm)

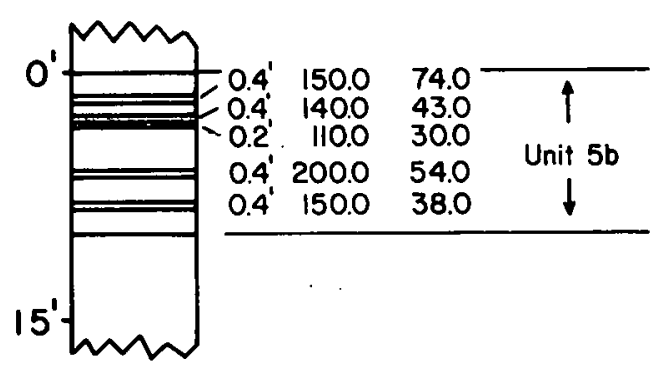

$E M B=10$

\section{EMB-9}

Figure $\mathrm{C}-22$.

Thickness and analysis for beds exceeding $100 \mathrm{ppm} \mathrm{U}_{3} \mathrm{O}_{8}$ in core from drill holes EMB-9 and EMB-10, Onemile Creek area, Medicine Bow Mtris. 


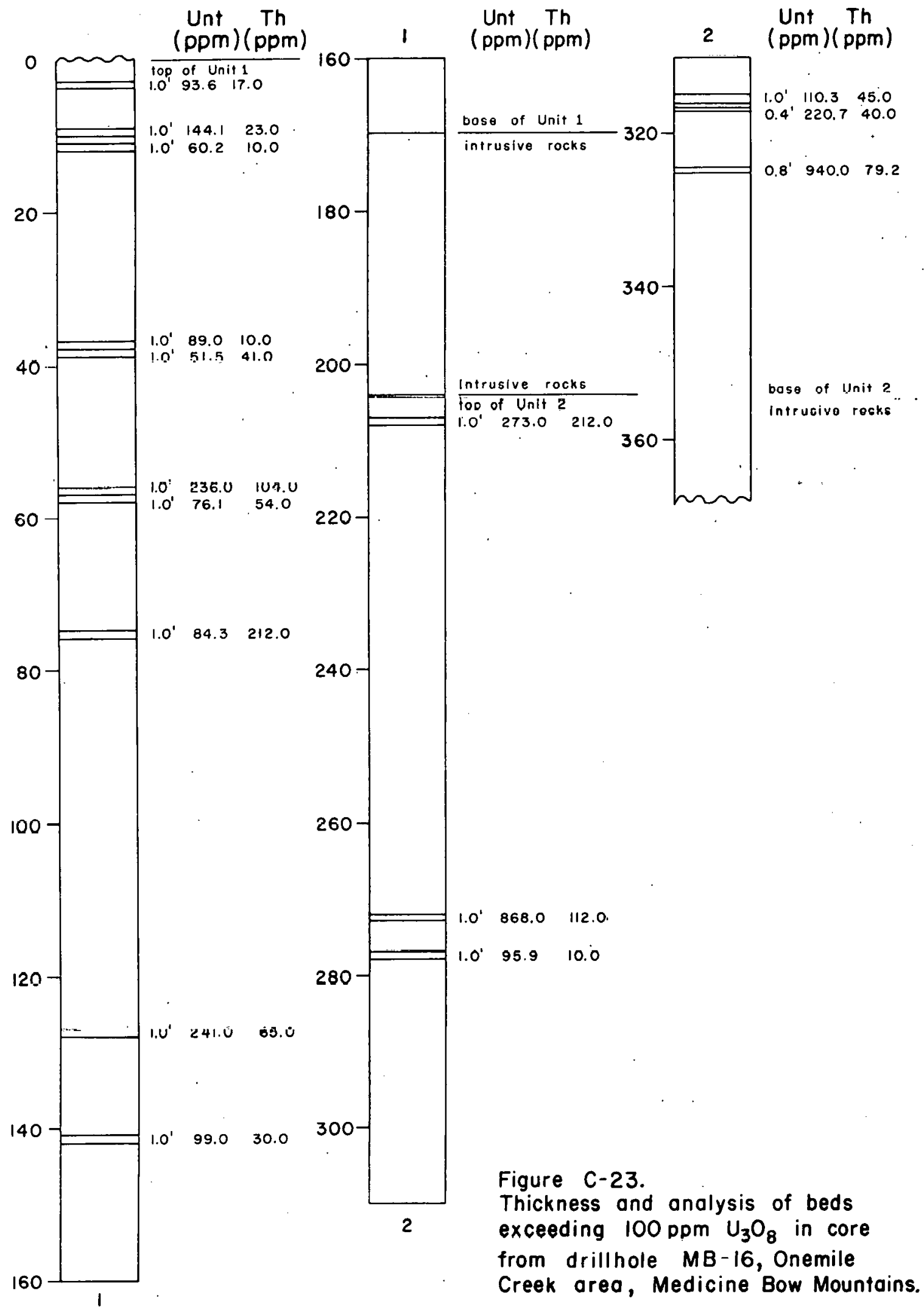



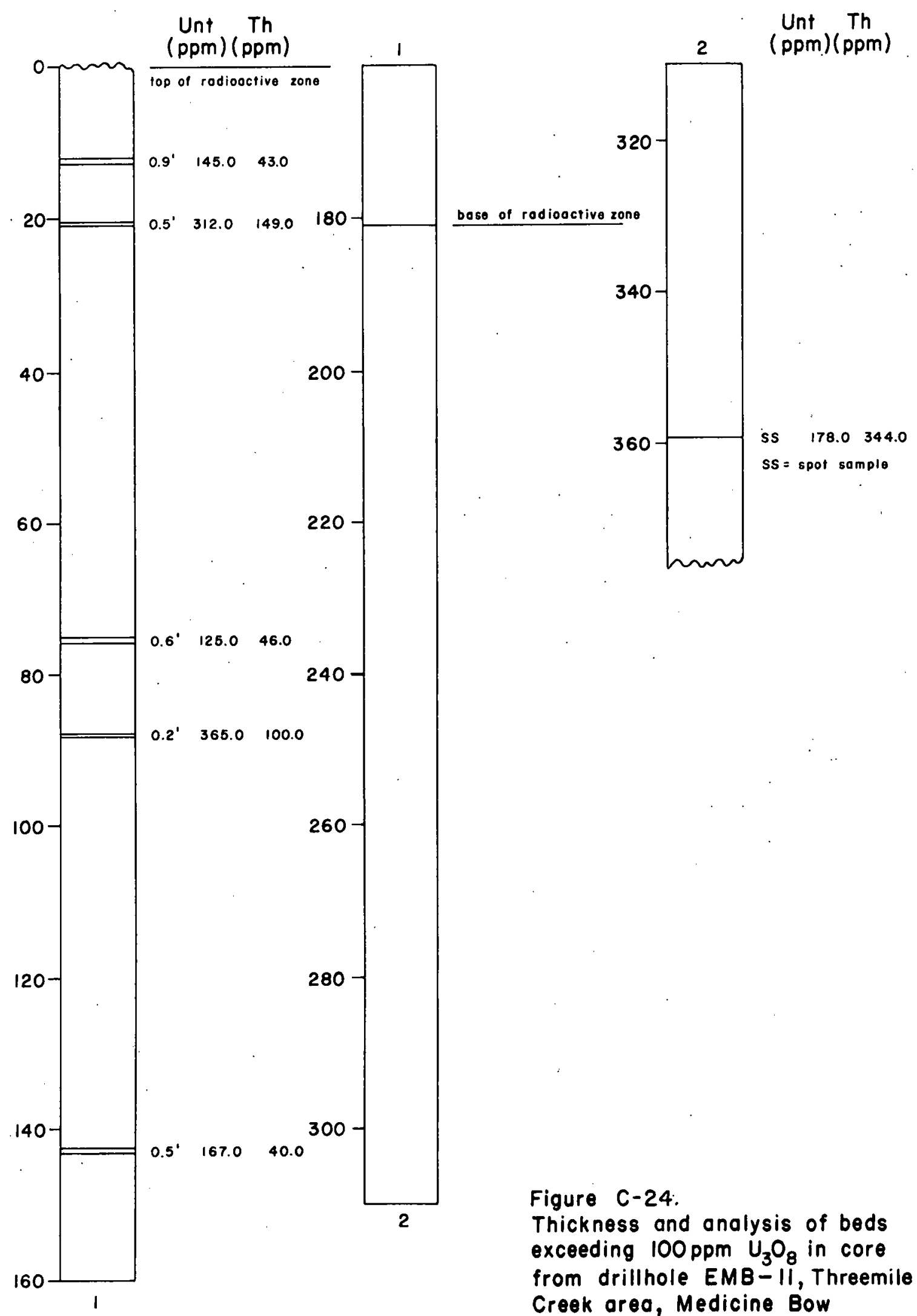

Figure C-24:

Thickness and analysis of beds exceeding $100 \mathrm{ppm} \mathrm{U}_{3} \mathrm{O}_{8}$ in core from drillhole EMB- $\|$, Threemile Creek orea, Medicine Bow Mountains. 


\section{THIS PAGE \\ WAS INTENTIONALLY \\ LEFT BLANK}




\section{Appendix D \\ Average Grade and Total Bed Thickness \\ for Outcrop Transects and Drill Holes}

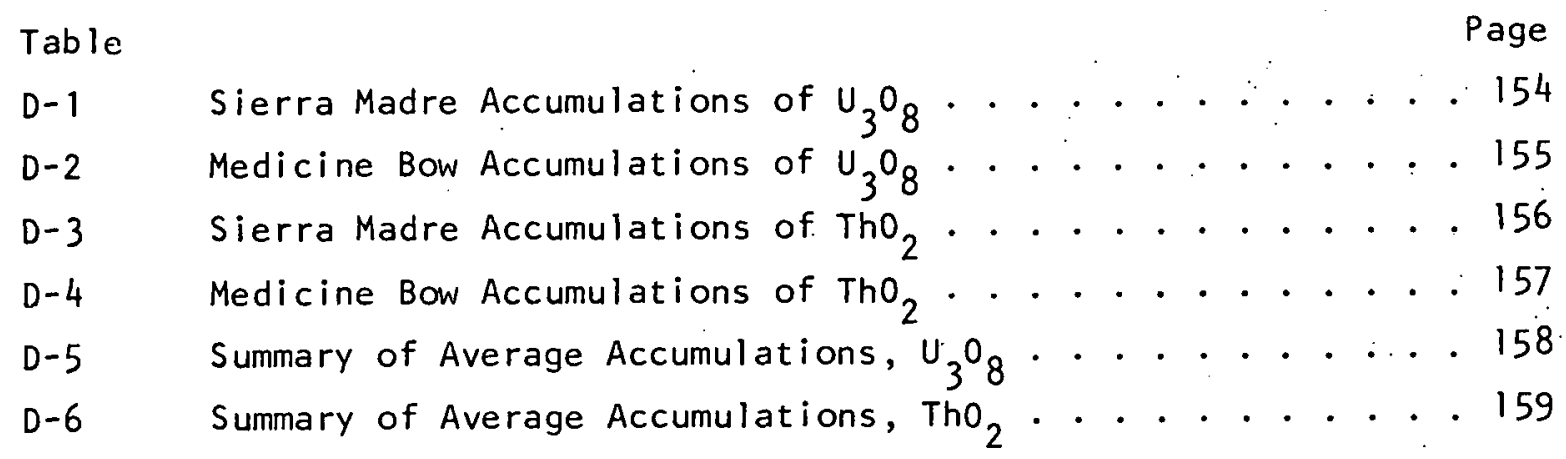


Table D-1

Sierra Madre Accumulations of $\mathrm{U}_{3} \mathrm{O}_{8}$ in exceedance of $100 \mathrm{ppm}$ Unit \#3

\begin{tabular}{llcccc}
\hline $\begin{array}{c}\text { Transect or } \\
\text { Drill Hole }\end{array}$ & $\begin{array}{l}\text { Average } \\
U_{3} 0_{8}\end{array}$ & $\begin{array}{c}\text { Average } \\
\left(U_{3} 0_{8}\right) 2\end{array}$ & $\begin{array}{c}\text { Average } \\
\text { In } U_{3} 0_{8}\end{array}$ & $\begin{array}{c}\text { Total } \\
\text { Thickness }\end{array}$ & $\begin{array}{c}\text { Average } \\
\text { Thickness }\end{array}$ \\
\hline Transect \#5 & 109.9 & 12077 & 4.70 & .7 & .7 \\
Transect \#16 & 116.03 & 13464 & 4176 & .5 & .5 \\
SM-1 Core & 110.6 & 12232 & 4.71 & .7 & .7 \\
SM-2 Core & 184.29 & 43423 & 5.12 & 4.2 & .60
\end{tabular}


Table D-2

Medicine Bow Accumulations of $\mathrm{U}_{3} \mathrm{O}_{8}$ in exceedance of $100 \mathrm{ppm}$

\begin{tabular}{lccccc}
\hline $\begin{array}{c}\text { Transect or } \\
\text { Drill Hole }\end{array}$ & $\begin{array}{c}\text { Average } \\
\mathrm{U}_{3} \mathrm{O}_{8}\end{array}$ & $\begin{array}{c}\text { Average } \\
\left(\mathrm{U}_{3} \mathrm{O}_{8}\right)^{2}\end{array}$ & $\begin{array}{c}\text { Average } \\
\mathrm{InU}_{3} \mathrm{O}_{8}\end{array}$ & $\begin{array}{c}\text { Total } \\
\text { Thickness }\end{array}$ & $\begin{array}{c}\text { Average } \\
\text { Thickne }\end{array}$ \\
\hline Unit 1: & & & & & \\
\hline Transect TIA & 164.04 & 34145 & 4.99 & 8.4 & 1.20 \\
Transect TIB & 207.20 & 48501 & 5.27 & 8.4 & 0.65 \\
Transect TIC & 403.02 & 327435 & 5.69 & 8.4 & 1.05 \\
Transect T2 & 245.24 & 83880 & 5.32 & 5.0 & 1.00 \\
EMB-1 Core & 175.31 & 33142 & 5.12 & 9.2 & 0.92 \\
MBI6 Core & 392.60 & 255433 & 5.66 & 15.2 & 0.95
\end{tabular}

Unit 5a:

Transect 74

$379.51: \quad 145567$

5.93

1.9

0.63

Transect 15

$369.23 \quad 151538$

5.86

9.4

3.13

Transect 78

$416.26 \quad 268186$

5.71

3.0

1.00

EMB-6 Core

424.77

276813

5.82

11.8

1.48

$E M B-7$ Core

195.73

71319

5.10

8.3

0.52

Unit 5b:

Transect T3

$175.97 \quad 95542$

4.82

2.8

1.40

Transect $T 5$

527.94

278678

6.26

0.6

0.60

Transect $T 7$

485.40

235613

6.18

1.0

1.00

Transect $T 8$

204.80

42608

5.31

3.0

1.00

EMB-6 Core

508.19

538639

5.76

15.4

0.96

EMB-7 Core

259.86

82586

5.45

6.7

0.37

EMB-8 Core

218.73

53081

5.32

4.8

0.69

EMB-9 Core

269.30

97202

5.39

1.0

0.50

EMB-10 Core

170.68

30032

5.12

1.8

0.36

Threemile

Creek. Area:

EMB-11 Core

$226.2 \quad 60521$

5.34

2.7

0.54 
Table' $D-3$

Sierra Madre Accumulations of $\mathrm{ThO}_{2}$ in exceedance of $100 \mathrm{ppm}$

Unit \#3

\begin{tabular}{|c|c|c|c|c|c|}
\hline $\begin{array}{l}\text { Transect or } \\
\text { Drill Hole }\end{array}$ & $\begin{array}{l}\text { Average } \\
\mathrm{ThO}_{2}\end{array}$ & $\begin{array}{l}\text { Average } \\
\left(\mathrm{ThO}_{2}\right)^{2}\end{array}$ & $\begin{array}{c}\text { Average } \\
\operatorname{lnThO}_{2}\end{array}$ & $\begin{array}{l}\text { Total } \\
\text { Thickness }\end{array}$ & $\begin{array}{r}\text { Average } \\
\text { Thickness }\end{array}$ \\
\hline Transect \#1 & 591.70 & 350118 & 6.38 & 2.0 & 2.0 \\
\hline Transect \#2 & 423.40 & 193168 & 6.00 & 4.3 & 2.15 \\
\hline Transect \#3 & 235.85 & 68743 & 5.35 & 5.5 & 1.83 \\
\hline Transect $\# 4$ & 162.24 & 27903 & 5.06 & 5.8 & 2.90 \\
\hline Transect \#5 & 341.35 & 116533 & 5.82 & .7 & .7 \\
\hline Transect \#6 & 216.20 & 46742 & $5 \cdot 36$ & 1.3 & 1.3 \\
\hline Transect \#7 & 257.75 & 67550 & 5.54. & 2.3 & 1.15 \\
\hline Transect \#9 & 130.47 & 17057 & 4.86 & 1.5 & .75 \\
\hline Transect \#10 & 202.75 & 44259 & 5.26 & 5.5 & 2.75 \\
\hline Transect \#11 & 131.37 & 17291 & 4.87 & 4.4 & 2.20 \\
\hline Transect \#13 & 156.20 & 26378 & 5.00 & 1.1 & .37 \\
\hline Transect $\# 14$ & 125.16 & 16832 & 4.80 & 1.0 & .33 \\
\hline Transect \#16 & 217.07 & 49381 & 5.35 & 1.3 & .43 \\
\hline Transect \#18 & 286.74 & 95090 & 5.57 & 1.5 & .50 \\
\hline Transect \#19 & 294.33 & 87149 & 5.68 & 1.5 & .75 \\
\hline Transect \#21A & 204.81 & 43386 & $5 \cdot 30$ & 1.3 & .32 \\
\hline Transect $\# 218$ & 146.3 & 21641 & 4.97 & .7 & .35 \\
\hline Transect \#22A & 329.99 & 108894 & 5.79 & 1.0 & 1.0 \\
\hline Transect \#22B & 227.57 & 51792 & 5.42 & .9 & .45 \\
\hline Transect $\# 23$ & 329.98 & 119252 & 5.74 & .9 & .45 \\
\hline Transect $\not 24$ & 466.53 & 217658 & 6.13 & .6 & .6 \\
\hline sin-1 Corre & 341.36 & 116532 & 5.82 & .73 & .73 \\
\hline SM-2 Core & 287.72 & 113536 & 5.5 & 8.96 & .64 \\
\hline
\end{tabular}


Table D-4

Medicine Bow Accumulations of $\mathrm{ThO}_{2}$ in exceedance of $100 \mathrm{ppm}$

\begin{tabular}{|c|c|c|c|c|c|}
\hline $\begin{array}{l}\text { Transect or } \\
\text { Drill Hole }\end{array}$ & $\begin{array}{l}\text { Average } \\
\mathrm{ThO}_{2}\end{array}$ & $\begin{array}{l}\text { Average } \\
\left(\mathrm{ThO}_{2}\right)^{2}\end{array}$ & $\begin{array}{l}\text { Average } \\
\text { In } \mathrm{ThO}_{2}\end{array}$ & $\begin{array}{c}\text { Total } \\
\text { Thickness }\end{array}$ & $\begin{array}{c}\text { Average Bed } \\
\text { Thickness }\end{array}$ \\
\hline \multicolumn{6}{|l|}{ Unit 1: } \\
\hline Transect TIA & 215.70 & 49540 & 5.33 & 2.3 & 0.77 \\
\hline Transect TIB & 170.09 & 34774 & 5.04 & 2.3 & 0.38 \\
\hline Transect TIC & 307.83 & 116724 & 5.56 & 1.9 & 0.95 \\
\hline Transect $\mathrm{T} 2$ & 307.28 & 94392 & 5.72 & 1.0 & 1.00 \\
\hline EMB-1 Core & 256.79 & 69967 & 5.51 & 3.0 & 1.00 \\
\hline$M B-16$ Core & 182.06 & 36658 & 5.14 & $3.2:$ & 0.80 \\
\hline \multicolumn{6}{|l|}{ Unit 5a: } \\
\hline Transect $T 4$ & 555.17 & 326314 & 6.29 & 1.9 & 0.63 \\
\hline Transect $T 5$ & 188.51 & 37128 & 5.21 & 6.7 & 1.12 \\
\hline Transect $T 8$ & 464.26 & 315377 & 5.78 & 5.0 & 1.00 \\
\hline EMB-2 Core & 159.30 & 25376 & 5.07 & 1.0 & 1.00 \\
\hline EMB-6 Core & 387.81 & 191748 & 5.83 & 8.0 & 1.33 \\
\hline EMB-7 Core & 270.97 & 88583 & 5.49 & 4.4 & 0.55 \\
\hline \multicolumn{6}{|l|}{ Unit 5b: } \\
\hline Transect $T 3$ & 147.92 & 21882 & 4.99 & 0.5 & 0.50 \\
\hline Transect T5 & 297.27 & 125548 & 5.48 & 1.6 & 0.80 \\
\hline Transect $\mathrm{T} 6$ & 100.13 & 100027 & 4.61 & 0.2 & 0.20 \\
\hline Transect $\mathrm{T} 7$ & 364.12 & 132589 & 5.89 & 1.0 & 1.00 \\
\hline Transect $T 8$ & 261.72 & 71603 & 5.54 & 3.0 & 1.00 \\
\hline EMB-6 Core & 255.64 & 86390 & 5.44 & 10.5 & 1.17 \\
\hline EMB-7 Core & 300.54 & 117203 & 5.56 & 6.4 & 0.40 \\
\hline EMB- 8 Core & 256.85 & 78249 & 5.46 & 9.6 & 0.74 \\
\hline EMB-9 Core & 642.90 & 567455 & 6.23 & 1.0 & 0.50 \\
\hline \multicolumn{6}{|l|}{$\frac{\text { Threcmile }}{\text { Creek Area: }}$} \\
\hline EMB-11 Core & 165.26 & 31371 & 5.04 & 1.7 & 0.43 \\
\hline
\end{tabular}


Table D-5

SUMMARY OF AVERAGE ACCUMULATIONS AND VARIANCES FOR $U_{3}{ }^{0} 8$

\begin{tabular}{|c|c|c|c|c|c|}
\hline Unit & $\begin{array}{l}\text { Average accumula- } \\
\text { tion of } \mathrm{U}_{3} \mathrm{O}_{8} \text { above } \\
100 \mathrm{popm}^{\circ} \\
(\mathrm{ppm} \times \mathrm{ft} .)\end{array}$ & $\begin{array}{c}\text { Average of } \\
\text { accumulations } \\
\text { squared } \\
(\mathrm{ppm} \times \mathrm{ft.})^{2}\end{array}$ & $\begin{array}{c}\text { Accumulation } \\
\text { variance } \\
(\text { ppm } \times f t .)^{2}\end{array}$ & $\begin{array}{c}\text { Number of } \\
\text { transects with } \\
\text { encounters of }>100 \\
\mathrm{ppm} \mathrm{U}_{3} \mathrm{O}_{8} \\
(\mathrm{k})^{2}\end{array}$ & $\begin{array}{l}\text { Total } \\
\text { number of } \\
\text { transects } \\
(n)\end{array}$ \\
\hline $\begin{array}{l}\text { Sierra Madre } \\
\text { unit } 3\end{array}$ & 246.60 & 153596 & 18806 & 4 & 31 \\
\hline $\begin{array}{l}\text { Medicine Bow } \\
\text { unit } 1\end{array}$ & 2551.73 & 9350811 & 3304805 & 6 & 6 \\
\hline $\begin{array}{l}\text { Medicine Bow } \\
\text { unit } 5 a\end{array}$ & 2415.49 & 8377562 & 2960192 & 5 & 9 \\
\hline $\begin{array}{l}\text { Medicine Bo'n } \\
\text { unit } 5 b\end{array}$ & 1455.88 & 7389445 & 4585649 & 9 & 10 \\
\hline $\begin{array}{l}\text { Medicine Bow } \\
\text { units } 1,5 a \\
\text { and } 5 b \\
\text { combined } \\
\text { (Onemi le Creek area) }\end{array}$ & 2024.53 & 8224884 & 3901555 & 20 & 25 \\
\hline $\begin{array}{l}\text { Medicine Bow } \\
\text { Threemile Creek area }\end{array}$ & 610.74 & 373003 & 57969 & 1 & 1 \\
\hline $\begin{array}{l}\text { All Medicine Bow } \\
\text { units }\end{array}$ & 1957.21 & 7850985 & 3842177 & 21 & 26 \\
\hline
\end{tabular}


Table D-6

SUMMARY OF AVERAGE ACCUMULATIONS AND VAF.IANCES FOR ThO 2

\begin{tabular}{|c|c|c|c|c|c|}
\hline Unit & $\begin{array}{c}\text { Average accumula- } \\
\text { tion of } \mathrm{ThO}_{2} \text { above } \\
100 \mathrm{ppm} \\
(\mathrm{ppm} \times \mathrm{ft} .)\end{array}$ & $\begin{array}{l}\text { Average of } \\
\text { accumulations } \\
\text { squared } \\
(p p m \times f t .)^{2}\end{array}$ & $\begin{array}{l}\text { Accumulation } \\
\text { variance } \\
(\text { ppm } \times f t .)^{2}\end{array}$ & $\begin{array}{c}\text { Number of } \\
\text { transects with } \\
\text { encounters of >100 } \\
\text { Th0 } 2 \\
(\mathrm{k})^{2}\end{array}$ & $\begin{array}{l}\text { Total } \\
\text { number of } \\
\text { transects } \\
(n)\end{array}$ \\
\hline $\begin{array}{l}\text { Sierra Madre } \\
\text { unit } 3\end{array}$ & 608.79 & 739051 & 344310 & 23 & 31 \\
\hline $\begin{array}{l}\text { Medicine Bow } \\
\text { unit } 1\end{array}$ & 522.07 & 294759 & 54267 & 6 & 6 \\
\hline $\begin{array}{l}\text { Medicine Bow } \\
\text { Lnit } 5 a\end{array}$ & 1515.53 & 3194760 & 1058781 & 6 & $\dot{9}$ \\
\hline $\begin{array}{l}\text { Medicine Bow } \\
\text { unit } 5 b\end{array}$ & 1048.37 & 2042130 & 941041 & 9. & 10 \\
\hline $\begin{array}{l}\text { Medicine Bow units } \\
1,5 a \text { and } 5 b \\
\text { combined } \\
\text { (Onemile Creek area) }\end{array}$ & 1007.01 & 1847084 & 830330 & 21 & 25 \\
\hline $\begin{array}{l}\text { Medicine Bow } \\
\text { Threemile Creek area }\end{array}$ & 280.94 & 78928 & 10275 & 1. & 1 \\
\hline All Medicine Bow units & 974.01 & 17667.13 & 815667 & 22 & 26 \\
\hline
\end{tabular}

